\title{
Splanchnic amino acid and ammonia metabolism : studies in the pig
}

Citation for published version (APA):

van Berlo, C. L. H. (1988). Splanchnic amino acid and ammonia metabolism : studies in the pig. [Doctoral Thesis, Maastricht University]. Rijksuniversiteit Maasticht. https://doi.org/10.26481/dis.19880930cb

Document status and date:

Published: 01/01/1988

DOI:

10.26481/dis.19880930cb

Document Version:

Publisher's PDF, also known as Version of record

\section{Please check the document version of this publication:}

- A submitted manuscript is the version of the article upon submission and before peer-review. There can be important differences between the submitted version and the official published version of record.

People interested in the research are advised to contact the author for the final version of the publication, or visit the DOI to the publisher's website.

- The final author version and the galley proof are versions of the publication after peer review.

- The final published version features the final layout of the paper including the volume, issue and page numbers.

Link to publication

\footnotetext{
General rights rights.

- You may freely distribute the URL identifying the publication in the public portal. please follow below link for the End User Agreement:

www.umlib.nl/taverne-license

Take down policy

If you believe that this document breaches copyright please contact us at:

repository@maastrichtuniversity.nl

providing details and we will investigate your claim.
}

Copyright and moral rights for the publications made accessible in the public portal are retained by the authors and/or other copyright owners and it is a condition of accessing publications that users recognise and abide by the legal requirements associated with these

- Users may download and print one copy of any publication from the public portal for the purpose of private study or research.

- You may not further distribute the material or use it for any profit-making activity or commercial gain

If the publication is distributed under the terms of Article $25 \mathrm{fa}$ of the Dutch Copyright Act, indicated by the "Taverne" license above, 


\title{
SPLANCHNIC AMINO ACID AND \\ AMMONIA METABOLISM
}

\author{
STUDIES IN THE PIG
}

\section{Proefschrift}

ter verkrijging van de graad van doctor aan de Rijksuniversiteit Limburg te Maastricht, op gezag van Rector Magnificus, Prof. dr. F.I.M. Bonke.

volgens het besluit van het College van Dekanen, in het openbaar te verdedigen op vrijdag 30 september 1988 om 16.00 uur

door

CAROLUS LEONARDUS HUBERTUS VAN BERLO

geboren te Maastricht 
Promotor : Prof.dr. P.B. Soeters

Promotiecommissie: Prof.dr. F. ten Hoor

Prof.dr. M.A. Allessie

Prof.dr. J.A. Flendrig

Dr. R.A.F.M. Chamuleau

Prof.dr. J.H.P. Wilson

CIP-DATA KONINKLIJKE BIBLIOTHEEK, DEN HAAG

Berlo, Carolus Leonardus Hubertus van

Splanchnic amino acid and ammonia metabolism: studies in the pig / Carolus Leonardus Hubertus van Berlo -[S.I. : s.n.].-IIl.

Thesis Maastricht. - With ref. - With summery in Dutch ISBN 90-9002406-9

SISO 605.16 UDC 59.06:61(043.3)

Subject headings: splanchnic metabolism / ammonia acid splanchnic / amino splanchnic.

(a) C.L.H. van Berlo

No part of this book may be reproduced or used in any way without the prior written permission from the author. 
To Marijke, to our parents. 



\section{CONTENTS}

CHAPTER 1: INTRODUCTION.

CHAPTER 2: $\quad$ ANIMAL MODEL, TECHNIQUES, AND MBASUREMENTS.

2.1. CHOICE OP THE PIG.

2.2 A TECHNIQUE TO SIUDY SPLANCHNIC METABOLISM IN THE UNRESTRAINED CONSCIOUS PIG.

2.3. FULLY AUTOMATED DETERMINATION OF AMINO ACIDS BY HIGH PERFORMANCE LIQUID CHROMATOGRAPHY.

2.4. THE DETERMINATION OF AMMONIA IN PLASMA AND WHOLE BLOOD.

CHAPTER 3.1: $\quad$ IS INCREASED AMMONIA LIBERATION AFTER BLEEDING IN THE DIGESTIVE TRACT THE CONSEQUENCE OF COMPLETE ABSENCE OF ISOLEUCINE IN HEMOGLOBIN ? A STUDY IN PIGS.

CHAPTER 3.2. $\quad$ EFFECIS OF ISOLEUCINE ADMINISIRATION ON AMINO ACID METABOLISM AFTER INTESTINAL BLEEDING: A STUDY IN PIGS.

CHAPTER 4: PORCINE INTESTINAL AMMONIA LIBERATION: INFLUENCE OF FOOD INTAKE, LACTULOSE AND NEOMYCIN TREATMENT.

APPENDIX 1: NORMAL ARTERIAL, PORTAL, AND HEPATIC AMINO ACID, AMMONIA, UREA, AND LACTATE LEVELS DURING PROLONGED FASIING.

APPENDIX 2* AMINO ACID CONTENT OF PLASMA AND WHOLE BLOOD.

SUMMARY.

SAMENVATTTNG.

REFERENCES.

CURRICULUM VTTAE

DANKWOORD. 
. 


\section{CHAPTER 1}

\section{INTRODUCTION}

\subsection{Aims of the thesis.}

Ammonia is thought to have a central role in the aetiology of porta systemic encephalopathy (PSE) (Cooper 1984). 75\% Of the intestinal ammonia liberation, which is the chief source of plasma ammonia is derived from gut glutamine metabolism (Weber 1979). The intestine therefore is more than just an organ of digestion and absorption. Its role in glutamine metabolism makes it an organ of importance in regulating body nitrogen pools not only in PSE but also during catabolic states. Souba et al (1985) notified an important role for intestinal nitrogen regulation after operative trauma. Elwyn (1968) was one of the pioneers in assessing the regulatory role of the gut and liver in amino acid metabolism in living dogs on a horsemeat diet. Since then many qualitative and quantitative investigations have been performed. Still the physiologic role in amino acid regulation of different parts of the splanchnic bed are considered largely unclarified. Only a few studies have tried to quantitate amino acid metabolism in the gut in physiologic and pathophysiologic situations (Rerat 1976, 1980, 1985; Bark 1980; Heberer 1985; Souba 1985). Earlier in vitro and in vivo studies from our laboratory in normal and germfree rats confirmed the importance of intestinal glutamine utilization in ammonia liberation, indicating a more important role for the small bowel (Van Leeuwen 1985). The mode of action of lactulose and neomycin in lowering systemic ammonia levels during liver insufficiency has always been associated with bacterial mechanisms. However lactulose treatment could not be associated with changes in intestinal flora. Furthermore neomycin proved not only to alter bacterial flora but also to induce changes in intestinal enzyme patterns. In vivo studies revealed that lactulose and neomycin altered intestinal glutamine metabolísm. Diminished glutamine metabolism resulted in decreased porta-arterial difference in ammonia, alanine, citrulline and glutamic acid. The possibility of decreased ammonia absorption however could not be ruled out. The unsophisticated nature of these experiments, in particular the sampling of blood from the large and small intestine in a semi in vivo situation and the limited amount of blood available, warrant further studies in a larger animal. The aims of the present investigations were:

1. To study and evaluate plasma amino acid and ammonia patterns in a qualitative and quantitative way in different areas of the splanchnic circulation in pigs, before, during and after oral protein ingestion (Chapter 3).

2. To measure and evaluate differences in ammonia producing potential between mixed protein and various blood constituents ingested orally, in different areas of the splanchnic circulation in pigs (Chapter 3).

3. To investigate qualitative and quantitative aspects of the effect of neomycin and lactulose treatment in an in vivo situation on small and large bowel a- 
mino acid and ammonia metabolism, before and after protein ingestion (Chapter 4).

\subsection{Background.}

1.2.1. The role of ammonia in postulated pathogenesis of hepatic encephalopathy.

Porta systemic encephalopathy is a clinical syndrome characterized by abnormal mental status occurring in patients with severe hepatic insufficiency (Sherlock 1954; Summerskill 1956). There is no general agreement as to which neuroactive metabolites might be of importance in the pathogenesis of hepatic encephalopathy (Jones 1983; Conn 1978). Many metabolic functions of the liver can be deranged in liver failure so that potentially a large number of neurotoxic metabolites can possibly contribute to the neural inhibition of hepatic encephalopathy. Several hypotheses have been considered concerning the biochemical mechanisms underlying PSE:

1. Ammonia metabolism alone has been implicated in the pathogenesis of hepatic coma (White 1955; Schwartz 1953; McDermott 1958; Conn 1979). Other reports suggest that ammonia may exert its action via:

a. Depletion of $\alpha$-keto-glutarate resulting in a fall of high energy phosphate and oxygen consumption (Fazekas 1957).

b. An acute toxic effect of ammonia on brain metabolism (Hawkins 1973).

c. An effect on neurotransmission (Raabe 1984, 1985; Deutz 1988).

2. Zieve hypothesized a synergism between ammonia, methionine, mercaptans and short-chain fatty acids as putative toxins (Zieve 1981). Ammonia toxicity increased three to four times by addition of methanethiol. The coma dose of sodium octanoate in the presence of methanethiol was one third the dose required to induce coma by the short chain fatty acid alone.

3. James et al (1979) claim that hyperammonemia raises the concentration of neutral amino acids in the brain resulting in changes in neurotransmitter metabolism. Ammonia stimulates brain-glutamine synthesis, resulting in increased outward transport of glutamine at the expense of the exchange for plasma neutral amino acids. During liver disease the plasma neutral amino acid profile is distorted. Therefore increased transport of neutral amino acids over the blood brain barrier results in a distorted pattern in the brain, especially increased levels of aromatic amino acids. Aromatic amino acids are precursors of neurotransmitters. The whole sequence may result in a distorted neurotransmitter pattern leading to encephalopathy.

4. The GABA theory proposed by Jones et al (1984) did not include a role for ammonia. He hypothesized that during liver insufficiency impaired he- 
patic metabolism of gut-derived gamma-amino-butyric acid (GABA) occurs, which accumulates in the systemic circulation. Increased uptake of plasma GABA by the brain in liver failure is claimed to occur across an abnormally permeable blood-brain barrier. It is suggested that GABA so transported may contribute to the neural inhibition of hepatic encephalopathy.

Zeneroli described the presence of pathologic changes in GABA receptors in hepatic encephalopathy characterized by a denervation supersensitivity phenomenon in the mild stage followed by a selection of high affinity GABA recognition sites in the severe stage apparently due to a loss of low affinity receptors. An increased number of GABA receptors in the brain during liver failure increasing the sensitivity of the brain to GABA-ergic neural inhibition, as proposed by Jones, may be abandoned. Recently, evaluating the different parts of the excess GABA hypothesis, we encountered that not only gut flora, but also the metabolism of glutamine, even in germfree animals, may contribute to GABA production (Van Berlo 1987). More importantly the findings in rabbit models of acute (galactosamine induced) and chronic (porta-caval shunted) liver insufficiency and acute organ damage (ligation of bowel or kidney), reveal that acutely reduced liver function does not alter the blood-brain permeability. It appeared that unspecific organ damage and cell necrosis (liver, kidney, bowel) induces a probably common chain of events which includes increased blood brain permeability (Van Berlo 1988). These remarks would not apply to the postulated GABA depletion theory, in which hyperammonemia in the brain leads to glutamate consumption, resulting in glutamine. Depletion of glutamate, a precursor of GABA, may lead to a decreased GABA formation, which may induce PSE (Kardel 1974; Iversen 1982). During the last International Symposium on Ammonia (Soeters 1988) a revival was observed in the interest in ammonia as the leading toxin in PSE.

\subsubsection{Dual function of the gut: absorption and metabolism.}

The gastrointestinal tract is generally viewed as an organ of digestion and absorption (Souba, 1985). Carbohydrates, fat, and proteins firstly are digested into compounds which are small enough for absorption, and are subsequently absorbed via different routes. Most of the triglycerides are ernulsified under the influence of bile and are finally split into monoglycerides, free fatty acids, and glycerol. The enterocytes of the small bowel package these products of lipid digestion into chylomicrons, which are transported via the lymphatics to the systemic circulation. Simple sugars and amino acids, endproducts of carbohydrate and protein hydrolysis, are absorbed by specific carriers on the luminal side of the intestinal epithelium into the enterocyte and subsequently transported across the basolateral membrane into the portal circulation. The anatomical relationship of the intestinal tract and the liver gives these organs a central role in the handling and processing of ingested nutrients. During the past few years many studies have demonstrated that the gastrointestinal tract actively metabolizes circulating substrates, specifically with respect to protein metabolism (Hanson 1977; Souba 1983, 1984, 1985; Windmueller 1975, 1980, 
1982). Although intestinal protein is preferentially synthesized from amino acids derived from the lumen (Hirschfield 1969), there is in addition a role for blood-borne amino acids, especially in the fasted state (Windmueller 1974, 1975, 1980, 1982; Wolff 1972). Absorbed amino acids are not only used for intestinal protein synthesis, some are also used as fuel sources e.g. glutamine (Windmueller 1975, 1980, 1982). More than 70\% however reaches the portal circulation, and are utilized elsewhere for protein synthesis (Rerat 1985; Bark 1980).

\subsubsection{Modes of ammonia production in the gut.}

Increased plasma ammonia levels are common in patients with porta-caval shunting and/or liver disease (Zieve 1981; James 1979). In animal models of liver disease, whether acute (galactosamine) or chronic (porta-caval shunting) increased systemic ammonia levels are also observed. In encephalopathies associated with certain congenital diseases and in Reye's syndrome high ammonia levels may be found (Campbell 1973; Hilty 1974; Flannery 1982). Several early reports describe the development of hepatic coma in patients with severe liver disease after ingestion of protein (nitrogenous material) (Gabuzda 1952; Stahl 1952; Philips 1952). Since then many studies have been performed, evaluating the possible mechanisms of ammonia toxicity during hepatic failure. The effects of orally administered ammonium salts, urea, glycine, and protein have also been studied in relation to their ability to increase ammonia production (Hoyumpa 1979). Ammonia generation in the gut occurs in several ways. It has been argued that most of the ammonia-liberating reactions of the intestine are mediated by bacterial enzymes within the intestinal lumen rather than by the intracellular intestinal wall metabolism. Hydrolysis of urea, and deamination of incompletely absorbed protein, amino acids and deamidation of glutamine have been attributed to bacterial action, especially in the colon (Jones 1983). Although glutamine yields significant amounts of ammonia, other amino acids can yield ammonia. All amino acids that are in excess of requirements, whether arising from the dietary intake or from the catabolism of tissue protein, will via several pathways (deamination or deamidation, and sometimes after transamination) ultimately result in the formation of ammonia (Bender 1985). A quantitatively important pathway for the production of ammonia from amino acids is by way of amino transfer to glycine, followed by oxidative deamination to the oxo-acid glyoxylate, catalyzed by the flavoprotein glycine oxidase. Ammonia is also produced as the result of the non-oxidative deamination of serine and threonine and by the oxidation of amines, catalyzed by amine oxidases. PSE is most commonly precipitated by protein administration (Sherlock 1954; McDermott 1954; Mutchnick 1974; Conn 1981). Protein-induced PSE has been divided in an exogenous and an endogenous form (Conn 1981). Induction by dietary protein in patients with a porta-caval shunt, is the classic example of the exogenous type (McDermott 1954; Fessel 1972; Mutchnick 1974). In non-shunted cirrhotic patients high gastrointestinal bleeding is the most common cause of hepatic encephalopathy (Gaustad 1949; McDermott 1954; Summerskill 1957). The breakdown of protein results in formation of ammonia, u- 
rea, oligopeptides, amino acids, and other nitrogenous substances. It is not clear which of these is the most important precipitant in protein induced PSE. A hierarchy in the degree of toxicity, often in parallel with the ammonia liberating potential, of different types of protein has been described (Greenberger 1977; Uribe 1985; Keshavarzian 1984; Young 1957; Bessman 1958, 1963). Gram for gram blood appears to be more toxic than meat, which in turn is more toxic than dairy or vegetable protein (Conn 1981). The importance of these observations resides in the fact that bleeding from the gastrointestinal tract often heralds PSE (Newell 1984). Bessman and Mirick (1958) and Young (1957) reported a higher increase in blood ammonia following the oral intake of blood than after an equal amount of milk protein. Fenton et al (1966) suggested that dairy protein is less toxic than meat, and Greenberger, Carley and Schenker (1977), proposed the same for vegetable protein. Smith et al (1964) found a greater toxicity following administration of casein hydrolysates than after pure casein, but were unable to confirm the greater toxicity of meat than dairy protein. Greenberger (1977) proposed a better protein tolerance during short term vegetable protein studies, based on a more positive nitrogen balance because of decreased urinary urea excretion. A better vegetable protein tolerance was also observed by Morgan (1981), Uribe (1982), Jeppson (1984) and Jonung (1987). De Bruijn (1983) described the same trend in a long-term study with stable postshunt cirrhotic patients. The difference in toxicity of the various proteins has been ascribed to many influences. Differences in composition of protein may cause differences in rate of digestion and in the mechanism of absorption (Conn 1981). Differences in amino acid composition may have biochemical and physiological consequences (Conn 1981). Rudman (1973) described differences in ammonia release of various amino acids; a high potency group of directly deaminating or deamidating amino acids (glycine, serine, threonine, glutamine, histidine, lysine, and asparagine) was compared with less potent amino acids (leucine, alanine, valine, phenylalanine, isoleucine, tyrosine, proline, and arginine, aspartic acid, glutamic acid, tryptophan, and the non-amino acid urea). These amino acids yield ammonia indirectly i.e. after transamination. "Synergism" might even complicate this picture as has been described for arginine, decreasing the ammoniagenic effect of glycine or mixtures of amino acids (Fahey 1957; Gullino 1956; Greenstein 1956). A difference between meat and vegetable protein on the basis of methionine is unlikely as gram quantities of methionine are needed to induce coma, while these diets contain significantly different but comparatively minute quantities (Greenberger 1977). Besides, Morgan et all (Crossley 1984) did not observe a deterioration when adding methionine to vegetable diets of patients. Bessman bas proposed hemodynamic consequences of the amino acid composition (In: Conn 1981). He postulated increased shunting of blood, permitting potential toxic nitrogenous products of digestion to escape liver metabolism, after the ingestion of proteins rich in histidine, known to have a portal vasoconstrictive effect. Another explanation was offered by Rudman (1973) namely that various foods might differ in free ammonia content. The amount of carbohydrates might influence ammoniagenesis (Brown 1967; De Bruijn 1986). A high intake of carbohydrate is known to augment renal ammonia generation (De Bruijn 1986). Uribe (1985) points at a 
role of dietary fiber, decreasing vegetable protein digestion, thus resulting in a more gradual supply of amino acids.

While reviewing the role of protein in the pathogenesis of PSE, it becomes clear that much emphasis has been put on bacterial metabolism. Intraluminal bacterial ammonia formation does not explain why germfree-animals can develop hyperammonemia as demonstrated by Nance (1971) and Sugarbaker (1987). Nance (1971) reported PSE in germfree Eck-fistula dogs with hyperammonemia, and showed that a blood meal induced the same increase in ammonia concentration. Sugarbaker (1987) demonstrated, in experiments performed in dogs, that decontamination of the gut did not result in a difference in small bowel ammonia production, indicating a non-bacterial mechanism. During the last few years many investigators reported a role for glutamine in ammonia production independent of bacterial action. Windmueller and Spaeth (1975) have demonstrated, in isolated and in vivo vascularly perfused preparations of rat intestine, the importance of intestinal metabolism of glutamine, yielding ammonia, citrulline, alanine, and glutamate. Glutamine was either derived from the lumen or from the blood. Although in the fasting state arterial glutamine and glucose are used in about equimolar amounts, glutamine yields five times more carbon dioxide, and is therefore the major source of energy for the intestine as very little glutamine is available in the lumen (Windmueller 1978, 1982). In the fed state, food-borne luminal precursors compete for the same enzyme systems. Catabolism of glutamine is catalyzed by glutaminase, found at the inner mitochondrial membrane (Kovacevic 1983). The highest levels of this phosphate dependent enzyme are present in the jejunum (Windmueller 1982). These studies allow better understanding of the studies of Weber and Veach (1979). They stated that in dogs about $50 \%$ of total intestinal ammonia production is derived from small bowel glutamine utilization, while about $25 \%$ is derived from large bowel glutamine metabolism and the rest from bacterial metabolism.

\subsubsection{Amino acid interorgan relationships between gut and other tissues.}

The role of the digestive tract in regulating protein metabolism is exercised at different levels. The initial factor influencing the process of enzymatic hydrolysis and absorption of proteins is the transit time, principally determined by the pattern of gastroduodenal emptying (Auffray 1965, 1967; Laplace 1970, 1971, $1972,1974)$. The velocity and quantity of food leaving the stomach determine the contact of foodsubstances with the digestive secretions and absorptive surfaces. The principal determinant is the number and volume of meals (Hunt 1954; Chang 1968). Other factors delaying the gastric emptying are the carbohydrate (Hunt 1960; Elias 1968; Mehnert 1968; Reynell 1956; Buraczewski 1971) and fat content (Hunt 1968; Pirk 1970) of food ingested, and to a lesser degree, the nature of the protein ingested (Laplace 1974). The enzymatic digestion of protein occurs at different levels of the digestive tract (stomach, duodenum, small bowel) (Taylor 1968; Seigffers 1963). Subsequently further disintegration occurs by the proteolytic enzymes of the pancreatic and intestinal secretions. The amounts of proteolytic enzymes in the digestive tract are regulated by the quantity of dietary protein present in the intestinal lumen. The bin- 
ding of enzymes to proteins continues until there is an excess of enzyme in the gut lumen (Iber 1980). Part of the protein present in the intestinal lumen is of endogenous origin. This includes enzymes, proteins derived from desquamated epithelial cells and proteins derived from bacteria. Both exogenous and endogenous proteins are digested in the upper intestinal tract (Rerat 1974; Alpers 1972; Bark 1980). In the fasted state no exogenous amino acids are absorbed in the intestine, so that only amino acids from endogenous sources participate in interorgan exchange (figure 1, Elwyn 1968). In this state little individual variation is observed (Munro 1964; Scriver 1965; Souba 1985; Bark 1980; appendix 1.). Endogenous protein undergoes a relatively continuous digestion throughout the day in the middle part of the intestine (Rerat 1974; Pion 1964; Combe 1966). On the other hand protein synthesis continues albeit at a modest rate. The effect is net protein degradation in the gut, ensuring a continuing supply of essential amino acids to the liver and the peripheral tissues. Bacterial action is important in the digestion of endogenous protein (Reddy 1969). Labile proteins like enzymes in the digestive tract contribute to the continuing supply of essential amino acids to the organism (Twombley 1961). Interorgan flux in the fasting state can be characterized by a release of essential and nonessential amino acids from peripheral tissues (Munro 1964). The amino acid flux across skeletal muscle demonstrates a net release of amino acids, with glutamine and allanine accounting for $60 \%$ of total amino acid nitrogen released (Souba 1985). Glutamine comprises one half of the whole body pool of all free amino acids (Souba 1985). Together with alanine glutamine transports more than half of the circulating amino acid nitrogen (Ruderman 1975; Souba 1984). This glutamine is mainly metabolized in the gut yielding ammonia, alanine, glutamate and citrulline. The ammonia is trapped in the liver before reaching the systemic circulation. The liver uses alanime, derived from muscle and glutamine breakdown in the gut and kidney for gluconeogenesis. In the kidney glutamine serves as the main precursor for renal ammoniagenesis (Golden 1982; Phromphetcharat 1981), for gluconeogenesis. The liver has been demonstrated to have intercellular compartmentalization of the two enzymes regulating glutamine metabolism (Gebhardt 1983). Glutamine synthetase is localized exclusively in the perivenous hepatocytes whereas periportal hepatocytes have glutaminase activity. Ammonia that is not transferred into urea may therefore be detoxified by the formation of glutamine before entering the hepatic vein. Citrulline is utilized by the kidneys for the biosynthesis of arginine (Windmueller 1982). In muscle branched chain amino acids are transaminated with $\alpha$-keto-glutarate yielding glutamic acid. Free ammonia reacts with glutamate, catalyzed by glutamine synthetase to glutamine (Muhlbacher 1984). The digestion of protein (figure 1, Elwyn 1968) and the absorption of amino acids is such that very little nitrogen is spilled in the feces.

Intake of nitrogen may exceed 25 grams per day, only 1-2 grams of nitrogen appears in the stools. The end product of protein digestion is a mixture of amino acids and oligopeptides, which are absorbed by the enterocytes by a carrier mediated process (Guidotti 1978; Iber 1980). Specific transport systems are available for neutral, basic, and acid amino acids (Adibi 1967, 1969, 1970; Hellier 1973). The absorption of relatively large peptides, which occurs in 
young infants (Gardner 1984; Bender 1985), and absorption of di-, tri-, and tetrapeptides is quantitatively of little importance. Many of the oligopeptides are hydrolyzed in the brush border of the mucosa cells, so that, merely amino acids enter the portal circulation (Rerat 1976; Elwyn 1968). About 10 to $15 \%$ of intestinal protein is used in the intestinal wall for protein synthesis (Bronk 1966). Portal concentrations of nearly all amino acids are elevated after a protein rich meal (Van Slyke 1913; Armstrong 1973; Wolf 1972; Elwyn 1970; Rerat 1976). The composition of the mixture of amino acids appearing in the portal vein after consumption of a protein containing meal is close to that of the diet supplied, especially with respect to the essential amino acids (Rerat 1976). On the other hand a substantial modification of non-essential amino acids is noticed due to the transamination in the gut wall and uptake by the enterocyte (Rerat 1976; Windmueller 1974).

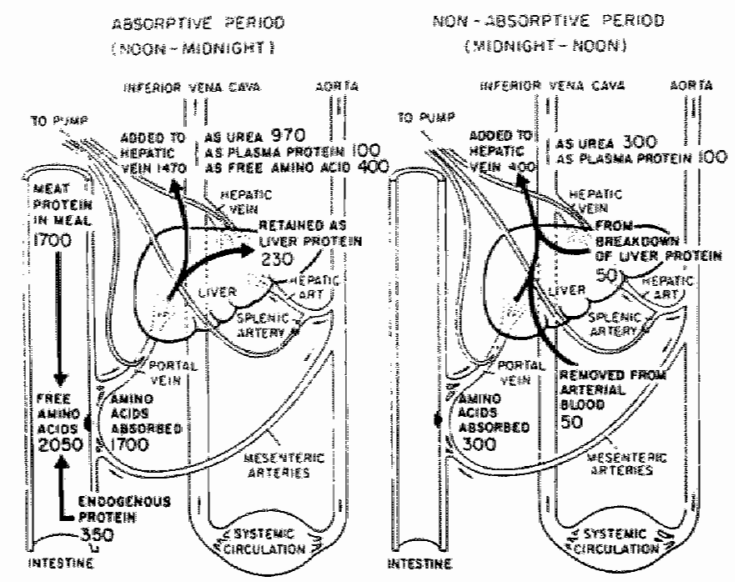

Figure 1. Movement of amino acids into, out of and within the splanchnic region during the absorptive period (12 hours after eating) and nonabsorptive period (12 hours before eating). All values are in mmolles $\mathrm{N}$ per kilogram of liver. Quantities, are mean values for 3 dogs fed daily at noon a diet of 780 grams of horsemeat per kilogram of liver. In converting weight of protein to numolles $\mathrm{N}$, it has been assumed that 1 mmole $\mathrm{N}$ corresponds to $87.5 \mathrm{mg}$ of protein (Ehwyn, 1968).

Following meals the liver encounters an increase in portal amino acid levels. A large portion is extracted by the hepatocytes (Elwyn 1968), incorporated in structural liver protein $(14 \%)$ or liver-borne secretory protein $(6 \%)$ (clotting factors, albumin, prealbumin, etc). Twenty three percent enters the general circulation in the form of free amino acids. Fifty seven percent of the absorbed nitrogen is converted to urea as it passes through the liver. Branched chain amino acids largely pass the liver unaltered and are incorporated in protein or degraded in peripheral tissues (Felig 1975). In skeletal muscle they are used for protein synthesis, but also as amino donors for the synthesis of glutamate and other amino acids. The resulting keto acids can be degraded in muscle yielding energy (Ruderman 1975). Catabolic disease states (figure 2) such as 
trauma, sepsis, major surgery, burns, and uncontrolled diabetes are characterized by accelerated skeletal muscle proteolysis and a flux of amino acids from the periphery to the visceral organs (Souba 1983, 1984, 1985). As mentioned previously, glutamine and alanine account for a major portion of the amino acids released by muscle during stress states. Despite increased skeletal muscle breakdown during critical illness, circulating concentrations of glutamine are diminished, indicating an increased uptake in other tissues (Kapadia 1982; Muhlbacher 1984; Souba 1983, 1984, 1985). Souba $(1983,1985)$ demonstrated a markedly increased glutamine consumption by the intestinal tract following operation, or glucocorticoid treatment. During glucocorticoid treatment the gut switched from an organ of glucose uptake to an organ of slight release (Souba $1984,1985)$. This ability of the gut to spare or even produce glucose characterizes catabolic illness. Increased glutamine metabolism in the gut results in ammonia and more alanine, which enter the gluconeogenic pathways in the liver.

\subsubsection{Therapy of hepatic encephalopathy.}

\subsubsection{Protein restriction and protein quality.}

The prevention and reduction of episodes of PSE is based on reduction of the ammonia content by decreasing ingestion of presumed ammoniagenic substrate, by suppressing ammonia production, by increasing hepatic and muscular ammomia extraction, and by removing ammonia from the body or converting it to less toxic nitrogenous products (Conn 1981). Keystone of therapy in decreasing the ammoniagenic substrate is the limitation of dietary protein (Conn 1981). The toxicity of protein and the consequence of protein digestion, may be minimized by a reduction of the amount of protein, and by administering multiple small meals. In the light of the hierarchy in toxicity of various proteins it might be advisable to avoid food containing high ammonia concentrations and to favor vegetable protein and casein over meat protein. The use of intravenously or orally applied synthetic mixtures of amino acids to normalize amino acid plasma levels in PSE is still controversial (Morgan 1986). Decreasing the amount of urea in the body is another effective method of reducing the ammonia content (Conn 1981). One way of doing this is by minimizing protein catabolism, by providing adequate amounts of carbohydrate continually throughout the day. A high fluid intake ensures a substantial urine flow. In ammonia suppressive therapy lactulose and antibiotics such as neomycin have widely been accepted as to be the first choice. These latter agents deserve a separate review, outlining bacterial and non-bacterial mechanisms, as they are the cornerstone of conventional PSE preventing therapy.

\subsubsection{Neomycin.}

Neomycin, an amino-glycoside isolated from a strain of Streptomyces fradiae is, by means of a number of active substances, effective against most gram-negative and some gram-positive aerobes, but not against the anaerobic flora (Imler 1975; Walter 1976). Silen (1955) described the ammonia lowering property of 
neomycin in superior mesenteric venous blood in experiments in dogs. As several investigators claimed beneficial effects in the treatment of PSE, it became the drug of choice despite its ototoxicity (Dawson 1957; Fischer 1957; Summerskill 1953; Stormont 1958; Paloon 1959). Neomycin was believed to exert its action on the aerobic flora. Several studies could not correlate the clinical improvement with bacteriological changes in the stools (Dawson 1957). Neomycin is known to cause mallabsorption of fat, carbohydrate, amino acids, carotene, d-xylose, vitamins $A$ and $K$, sodium and potassium, penicillin, bile acids, and long chain fatty acids (Hvidt 1963; Paes 1967; Asatoor 1967; Faloon 1958, 1970; Jacobson 1962; Levine 1967; Udall 1965; Cheng 1962; Powell 1962; Lacey 1968). Jacobson (1960), Dobbins (1968), and Van Leeuwen (1985) described histologic alterations associated with neomycin induced malabsorption. Most intriguing is the fact that the aerobic flora comprises less than $1 \%$ of the total faecal flora. Besides, anaerobes can also produce ammonia by virtue of their urease or deaminase activity. This led Van Leeuwen (1985) to investigate the influence of neomycin on gut wall intermediary metabolism. He reported a decrease in the activity of several mucosal enzymes, diminished ammonia production and glutamine degradation in in vitro and in vivo studies using normal and germfree Wistar rats (Van Leeuwen 1985, 1988). In summary, it can be concluded that the role of neomycin relies not only on its flora-modulating activity but also through changes in gut wall absorption and amino acid metabolism.

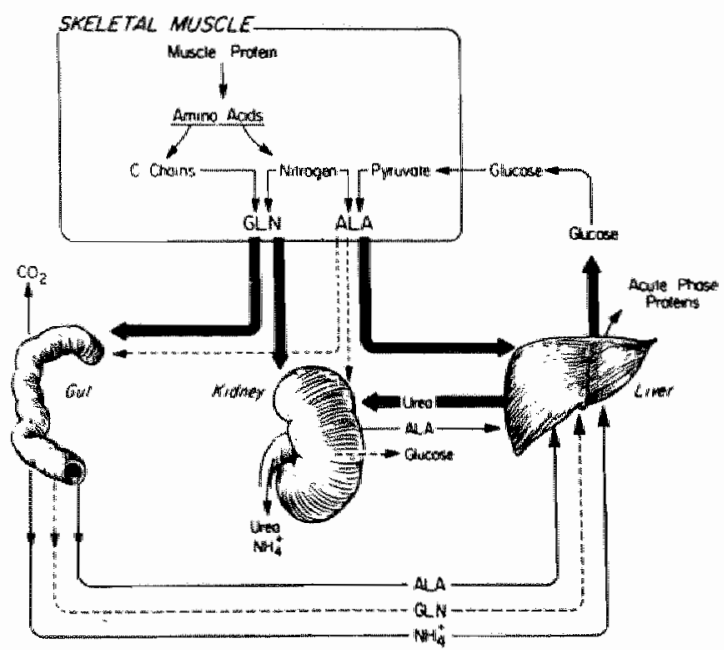

Figure 2. Diagram illustrating the interorgan exchange of glutamine (GLN), alanine (ALA), and ammonia $\left(\mathrm{NH}^{+}\right)$, (With permission of Prof D.W. Wilmore). 


\subsubsection{Lactulose.}

Lactulose, 1,4-beta-galactosido-fructose, is a synthetic water-soluble disaccharide (galactose-fructose) with a molecular weight of 342.3 . Man and animal are not known to be capable of hydrolyzing lactulose (Tanaka 1962). Only bacteria contain the necessary enzymes for its hydrolysis (Hoffman 1964). Experiments in mice, rats, rabbits, dogs, pigs, and humans did not reveal any side effects: lactulose can be considered a non-toxic drug (Conn 1981). Minor side effects seem to be limited to diarrhoea and abdominal gas. This is not surprising as lactulose is a non-absorbable disaccharide, it is not absorbed in the small bowel and its main site of degradation is in the colon. The principal metabolite of lactulose is lactic acid (Hoffman 1964). Also small amounts of volatile fatty acids and ethanol are generated, acidifying the stool. Many attempts have been made to explain the mode of action of lactulose. Bircher et al (1966) hypothesized that lactulose diminished the growth of urease containing bacteria. Intestinal flora modulation has not been supported by other investigators (Conn 1970; Vince 1974). Pitt (1980) investigated alterations in carbohydrate metabolism of colonic flora, as this might influence the degradation of lactulose. Lactulose-treated cirrhotics produced significantly less $\mathrm{H}_{2}$ than normal and cirrhotic controls. Another possible mode of action is through the trapping of ammonia in the acidified content of the bowel. The pH gradient between bowell lumen and blood should be responsible for a reduction in ammonia absorption. As the pH measured was never below 5.0 (Bown 1974) while the pKa of ammonia is 9.5, this mode of action is not very likely. Catharsis due to acidic products from lactulose breakdown seems a sound explanation for the mode of action of lactulose (Bennet 1976). This does not explain the lack of improvement in PSE after administration of mannitol and sorbitol, two compounds equally capable of acidifying the gastrointestinal content (Agostini 1972). Vince (1978) proposed that the preferential use of lactulose as an energy source for bacteria resulted in a decrease in ammonia production, due to a sparing effect of bacterial metabolism. None of the above mechanisms assumes a possible role for a decrease in non-bacterial ammonia formation. Van Leeuwen (1985) quantitated the rate of ammonia produced by isolated enterocytes and colocytes of normal and germfree rats and noted an attenuated ammonia production after addition of lactulose. Additional studies in an in vivo perfusing model confirmed these results, revealing interference with glutamine utilization. These preliminary results obtained in acutely sacrificed rats shed no light on ammonia and amino acid flux following protein ingestion. Such studies which are more applicable to a larger animal model as described in this thesis are described in chapters three and four. 


\section{CHAPTER 2}

ANIMAL MODEL, TECHNIQUES, AND MEASUREMENTS.

\subsection{CHOICE OF THE PIG.}

The earliest source of the use of animals in research is a drawing found in Vesalius's Fabrica, written in 1543, illustrating the resuscitation with a reed of an unanesthetized swine, after cutting the recurrent laryngeal nerve. Surgical research and the human treatment of animals have certainly advanced beyond this stage, but the example does demonstrate that the use of swine to investigate physiologic processes that apply to humans is not new. The choice of dogs as a large animal model has merely been based on tradition (Swindle 1983; Gay 1983; Loew 1981, 1982). No single animal species is exactly analogous to man in all aspects and the choice of an appropriate experimental animal should be based on physiologic and anatomic considerations. Many have proposed the pig as an experimental animal because of intestinal similarity with man (Sack 1982). Therefore the pig has been considered the ideal animal for nutrition studies (Benevenga 1986). It is not a carnivore like the dog, but rather an omnivore like man. The anatomy of the large and small intestine resembles that of humans. But also digestion, absorption, and intestinal flora resemble the human intestine (Bustad 1966; Pond 1978). These considerations prompted us to choose the pig in our studies, in which we manipulated food and protein intake, and tried to measure the importance of splanchnic regulation of amino acid metabolism. 

THE UNRESTRAINED CONSCIOUS PIG.'

\subsubsection{Abstract.}

In recent years similarities recognized between porcine and human anatomy and physiology have made the pig an experimental animal of considerable value in biomedical research. We developed a pig model, for unrestrained repeated sampling of portal and arterial blood, and selectively of small and large bowel veins. Catheters were inserted, under halothane amesthesia, in ten female crossbred (Yorkshire $x$ Dutch Landrace) piglets $(20 \pm 0.8 \mathrm{~kg})$. After recovery for at least three days the catheters were used for sampling of blood. Aortic and portal catheters patency rates were $60 \%$ at day 24 . For the small bowel catheters a patency rate of $30 \%$ was seen at day 24 . The large bowel patency rate was $30 \%$ at day ten. These results are promising because they allow longterm metabolic splanchnic research in unrestrained pigs.

\subsubsection{Introduction.}

Similarities recognized between porcine and human anatomy and physiology make the pig an animal model of considerable value in biomedical research (Mount 1971; Douglas 1972; Bähr 1972; Hörr 1973). While studying splanchnic amino acid metabolism in the laboratory, we needed a rellatively large animal allowing unrestrained repeated sampling of portal, arterial blood and selectively of veins of the small and large bowell. Methods for obtaining peripheral and total portal blood of cats, dogs, sheep, calves and pigs have been described (Denton 1953; Jungblut 1958; Levenson 1959; Longenecker 1958; Bessman 1948; Dent 1949; Annison 1955; Schambye 1955, 1955; Conner 1960; Barcroft 1944; Arsac 1962; Witzel 1973; Wingfield 1974; Mills 1967; Hamilton 1965; Katz 1969, 1969; Santiesteban 1983; Lydtin 1969; Christison 1969; Weirich 1970; Jackson 1972; Shimada 1973; Ford 1978; Manolas 1983; Kahn 1984; Takahashi 1986; Rerat 1976). The aim of this study is to report our experiences with a technique for obtaining simultaneously aortic, portal and, selectively, small and large bowel venous blood from unrestraimed, unanesthetized piglets.

\subsubsection{Material and methods}

\subsubsection{Animals:}

Female crossbred (Yorkshire $x$ Dutch Landrace) piglets $(n=10)$, about 8 weeks old, weighing $20 \pm 0.8 \mathrm{~kg}$ were used and housed individually inside in galvanized.

' C.L.H. van Berlo, A.E.J.M. van den Bogaard, M.C.F. Bost, P.B. Soeters. Lab. Anim. Sci. 1988, in press. 
bar runs ( 2 by 3 meters) equipped with an automatic watering device and PVC-coated floors.

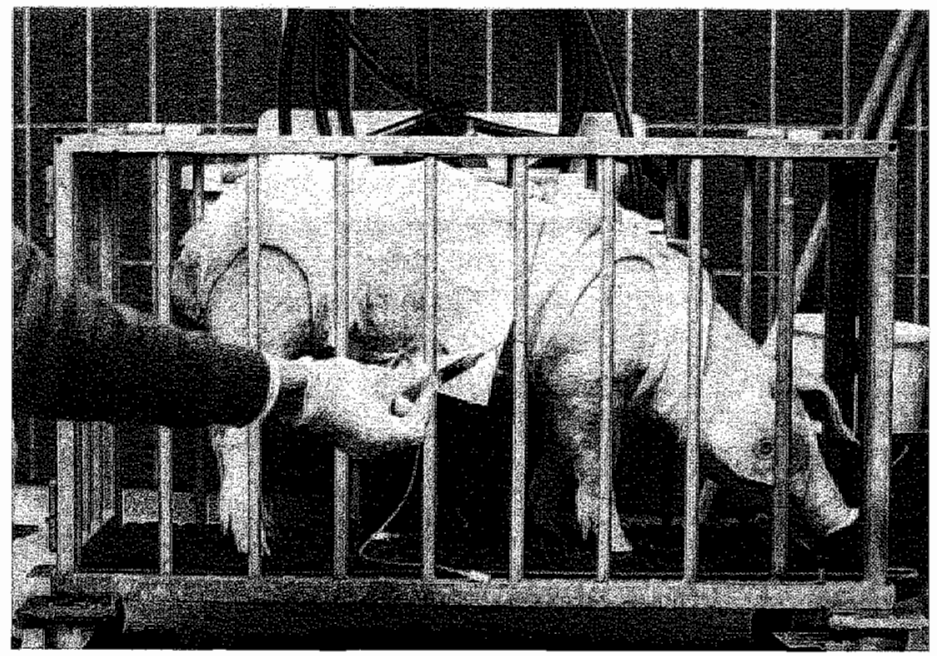

Figure 1. Pig fitted with a protective hamess, standing in a movable cage $(0.9 \times 0.5 \times 0.3 \mathrm{~m})$, during blood sampling.

Animals were placed in the pen and acclimated to their new surroundings for at least three days before surgery. During this period they were put daily in a small movable cage $(0.9 \times 0.5 \times 0.3 \mathrm{~m})$, used during blood sampling, twice daily for 30 minutes, to acclimate them to this procedure (figure 1). In stead of the usual pig feed ${ }^{1}$ ( $16 \%$ protein), pregnant sow feed ${ }^{2}$ (12\% protein) was given, to avoid rapid growing of these crossbred pigs. In this way growth was restricted to less than $1.5 \mathrm{~kg}$ per week.

\subsubsection{Surgical procedures:}

Animals were fasted for 24 hours. Half an hour after premedication (azaperon ${ }^{3}$ $8 \mathrm{mg} / \mathrm{kg}$, ketamine $10 \mathrm{mg} / \mathrm{kg}$ ) anesthesia was induced with thiopental sodium ${ }^{5}$ (25 mg/kg) via an ear vein, and ampicillin ${ }^{8}(25 \mathrm{mg} / \mathrm{kg}$ i.v) was given as antimicrobial prophylaxis (Van den Bogaard 1985). Anesthesia was maintained, after oral endotracheal intubation, with a nitrousoxide, oxygen (1:2), halothane ${ }^{7}$ $(0.8 \%)$ mixture. An infusion of lactated Ringer's solution ${ }^{8}(500-1000 \mathrm{ml})$ was

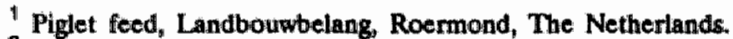

2 Pregnant sow feed, Landbouwbelang, Roermond, The Netherlands.

3 Azaperon, Stressiali ${ }^{\mathrm{P}}$, Janssen Pharmaceutica, Goirle, The Netherlands.

4 Ketamine HCl, Nimatek ${ }^{A}$, AUV, Cuijck, The Netherlands.

5 Thiopental sodium, Nesdonal ${ }^{\text {}}$, Rhone-Poulenc, Amstelveen, The Netherlands.

- Ampicillin, Kombivet ${ }^{A}$, Etten-leur, The Netherlands.

7 Halothane, ICI, Rotterdam, The Netherlands.

S Lactated Ringer's solution, Lactetrol", Boxtel, The Netherlands.
} 
given via the ear vein during surgery. The neck, thorax and abdomen were prepared for aseptic surgery. With the animal in dorsall recumbent position a skin incision was made over the ventral side of the neck, 1 to 2 centimeters laterall of the trachea. Using blunt dissection the carotid artery was exposed. The perivascular fascia was freed from the artery. Two sutures 2-0 Mersilene ${ }^{\text {(n) }}$ were loosely placed around the vessel. After proximal ligation a Tygon $^{\text {(f)2 }}$ (I.D. 0.04, O.D. 0.07 inch) catheter, filled with heparinized ${ }^{3}$ saline, it's tip precut to an acute angle, was inserted via an arteriotomy. The other end contained a blunt needle, closed with a screwtype stopcock ${ }^{5}$. The caudal ligation was firmly tied around the catheter. The proximal ligation was also fixed to the catheter and both ligatures were tied together to prevent displacement of the catheter. Then the catheter was tunneled subcutaneously to the animal's back where the free end lay behind the scapula. Furthermore, the other end was not fixed to the skin, allowing the catheter to be pulled through the skin with growth. The neck wound was closed in two layers 2-0 Vicrylpe, 2-0 Mersilene $\left.{ }^{(\mathrm{F})}\right)^{3}$. Subsequently a midline incision was made from the sternum to the pubic region. In a similar way catheters were inserted via a small branch into the superior mesenteric vein (enabling blood sampling from the small bowel) and via a splenic vein into the portal vein (tip palpable in the hillus). For the large bowel the colonic vein was exposed between two coils of the colon ascendens. Experience proved that an indirect approach via its very small branches was unpractical. Therefore we chose a direct approach, via a venotomy, with a purse string suture in the colonic vein itself. Care was taken not to obstruct the lumen. The three catheters were jointly led retroperitoneally, and thereafter via the musculature tunneled subcutaneously to the same opening as the carotid catheter (figure 2). The abdominal incision was closed with continuous 2-Mersilene ${ }^{\left(\mathbb{P A P}^{3}\right.}$ in the fascia, continuous 2-0 Catgut $^{{ }^{\circ}}$ subcutaneously, and continuous 2-Mersilene ${ }^{(7) 3}$ in the skin.

\subsubsection{Postoperative care:}

Postoperatively pigs were placed in their isolated heated pens. The catheters were filled with heparinized saline $(1000 \mathrm{U} / \mathrm{L})$, which was renewed after blood sampling or twice a week. No additional systemic anticoagulative medication was given. Pigs wore a canvas harness to protect the catheters, and to allow easier handling of the animals.

\subsubsection{Experiments:}

"Mersilene ${ }^{\mathrm{P}}$ Ethicon, Nondenstedt, Germany.

2. Tygon "Millipore, Dumee, Soest, The Nethertands.

3 Heparine, LEO Pharmaceutische Produkten B.V. Bmmen, The Netherlands.

4 Injection needle, $1.2 \times 40 \mathrm{~mm}$, Terumo Europe B.V., Belgium.

Braunule $G$ 16, B. Braun, Melsungen A.G., Germany.

- Vicryl ${ }^{\text {t }}$, Bthicon, Nonderstedt, Germany.

- Catgut, Ethicon, Norderstedt, Germany 
Experiments were started after at least three days recovery. In this period food and water intake returned to preoperative levels and the animals were socialized to the investigator and accustomed to the canvas harness. In our experiments we used the catheters during 24 days. Sampling was done while the conditioned, unrestrained, conscious animal was standing in a small movable cage $(0.9 \times 0.5 \times 0.3 \mathrm{~m})$. After each sampling each catheter was flushed with saline. After the last sampling of the day the catheters were filled with heparinized (1000 U/L) saline. After each sampling procedure the pig was returned to the run.

\subsubsection{Results}

The percentages of open catheters is plotted in figure 3 (Hop 1981; Berkson 1950). For the arterial and portal vein catheters a patency rate of $60 \%$ was seen at day 24 . For the small bowel catheter the patency rate was $30 \%$ at 24 days. The large bowel catheter exhibited a patency rate of $80 \%$ at day four and $30 \%$ at day ten.

\subsubsection{Discussion}

Our experience with pigs as a large animal model confirms previous reports that pigs are useful as a large laboratory animal provided that time is taken for acclimatization of the animal to its new surroundings and to the investigators (Mount 1971; Douglas 1972; Bähr 1972; Hörr 1973). In our design this model enabled us to obtain repeated blood samples from unrestrained conscious animalls. Although there are reports dealing with longterm blood sampling from arteries and portal vein in many species including pigs, we did not encounter publications concerning experiences with sampling of selectively small and large bowel venous effluent of young, growing animals.

The few results published describe superior mesenteric vein cannulations in adult animals, usually with the purpose of injecting dyes, rather than sampling blood (Conner 1960). The results of our arterial and portal catheters are comparable with those of others (Katz 1969; Weirich 1970; Jackson 1972; Manollas 1983). Four of the ten animals could not be used for experiments for different reasons. One animal developed peritonitis and died, one got catheter sepsis and was withdrawn from the study, one animal died from a volvulus (despite short intraabdominal catheter routes to minimize this risk) and in one animal the catheters were lost by accident (caught on the automatic watering device) despite canvas harness protection. In a pilot study we followed 3 animals for a longer period (up to 8 weeks) without encountering difficulties in arterial and portal catheters. The patency of the catheters in the veins of the small bowel was more troublesome. Three catheters stayed open until the date of termination. Four animals could not be used for reasons mentioned above. 


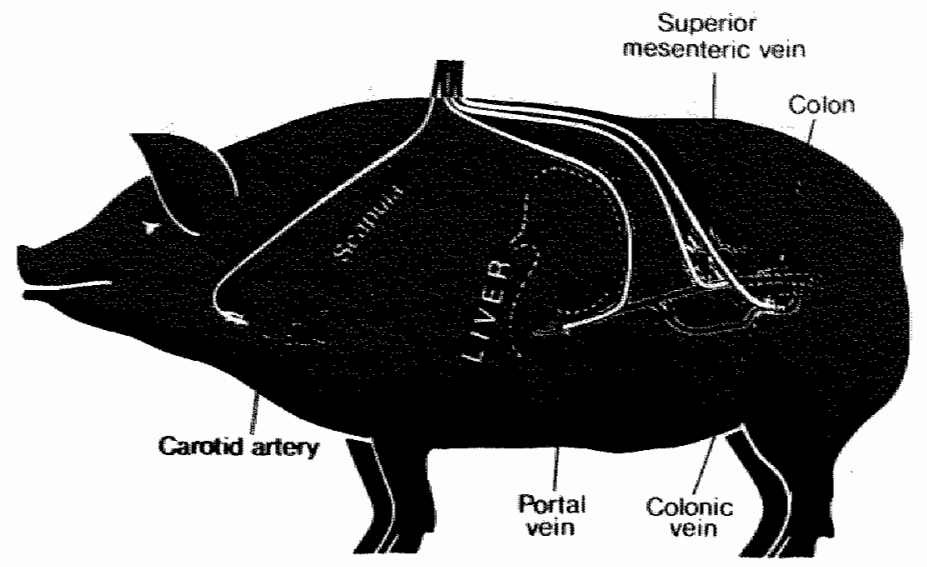

Figure 2. Schematic representation of catheters in situ showing simultaneous exit behind the scam pula.

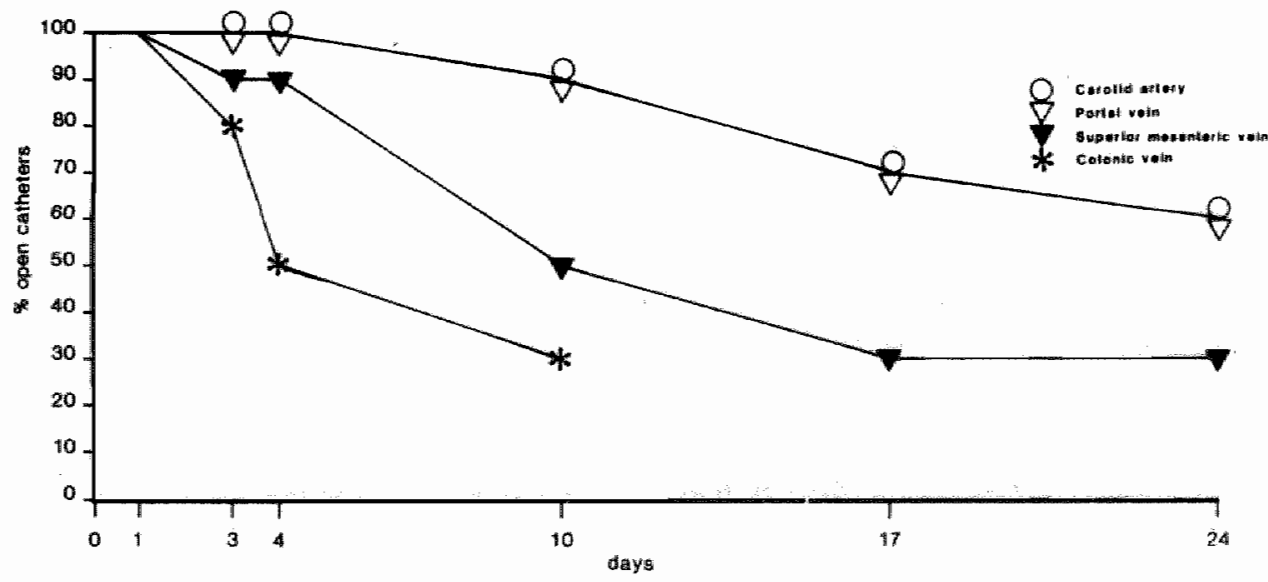

Figure 3. Patency rates of the various eatheters. 
In three animals two-way patency was lost, still enabling ws to inject dyes, on days 3,10 , and 17 , because of fibrin deposition around the catheter, acting as a valve. The use of a wire-guide as recommended by others (Katz 1969) was not possible because of the tortuous course of these abdominal catheters. Most trouble was encountered in the large bowel catheters. None of these functioned until the end of the study. However, we were able to selectively collect blood from the large bowel for up to ten days. Although we lost two way patency in all other animals after 3,4 and 10 days. Our direct approach to the colonic vein seemed better than the distally inserted inferior mesenteric vein catheter, both techniques failed to guarantee a patency of longer than 10 days duration. The present technique enables blood sampling of unrestrained, conscious pigs from aorta and portal vein for periods extending beyond our experimental 24 days. Although less reliable, small bowel venous effluent sampling was possible for periods of 24 days. Most difficulties were encountered during sampling of the venous effluent of the large bowel. This is due to the low and variable flow rate of this part of the gut. We were able to study simultaneously large and small bowel venous effluent, portal and aortic blood for a period of ten days in three of the ten animals. We consider this technique to be promising for metabolic splanchnic research especially in combination with electromagnetic flow probe implantation, enabling exact quantification of nutrient absorption over the intestinal tract (Rerat 1976; Charbon 1981).

\subsubsection{Quantification of flow.}

\subsubsection{Choice of electromagnetic flow measurements.}

Quantitating production or utilization of substances across an organ requires blood flow measurement plus the concentrations of the substrates involved (in arterial and venous blood) across the target organ. Determination of flux is based on the following formula:

$\mathrm{A}=(\mathrm{Cp}-\mathrm{Ca}) * \mathbf{f}$

$A=$ flux $(+=$ release, $-=$ uptake $)(\mathrm{mmol} / \mathrm{h})$

$\mathrm{Cp}, \mathrm{Ca}=$ portal and arterial substrate concentration $(\mu \mathrm{mol} / \mathrm{L})$

$f=$ portal flow $(1 / \mathrm{min})$

For the measurement of blood flow in large blood vessels direct or indirect methods have been described (Ohnhaus 1979). Indirect methods comprise dilution techniques (Grenvik 1966; Kowalski 1954; Jacobs 1969) employing indicators, such as sulfobromophtalein or indocyanine green, inert gas washout techniques $\left(\mathrm{H}_{2}, \mathrm{~N}_{2}\right)$, and radiolabeled microsphere techniques. The dilution and inert gas washout techniques are based on the disappearance (dilution) of injected markers. In the radiolabeled microsphere technique the number of particles impacted in a given tissue is proportional to the volume of particle containing blood injected, perfusing that tissue (Miller 1980; Tranquilli 1982). In case of 
intestinal flow measurements these techniques are not preferred (Heberer 1985) for seveal reasons:

1. The indicator concentration might be altered during its intestinal passage (absorption of water), while correction by simultaneous determination of hematocrit or hemoglobin requires additional blood sampling.

2. Indicator dilution techniques require repetitive blood sampling, which is best avoided in chronic experiments

3. Radiolabeling microsphere measurements are difficult in an organ as the intestine which frequently shunts blood (Delaney 1969).

4. The use of radiolabeled compounds requires special arrangements, which make determination of other substrates more troublesome.

5. These methods can not be used for continuous flow measurements, which are crucial in establishing the kinetics of absorption.

The direct methods include drop count techniques, heat exchange methods, doppler techniques (Peronneau 1971; Vatner 1970) and electromagnetic flow measurements (Wyatt 1984; Charbon 1981; Rerat 1976; Heberer 1985). The drop count and heat exchange techniques are not ideal for the reasons mentioned above. Doppler techniques and electromagnetic flowmeters can both be applied for portal flow measurements. Doppler flowmeters are useful in that no occlusive device is needed for the determination of the zero flow level. However advantages of the electromagnetic flowmeasurement above the doppler method are:

1. It is possible to detect reverse flow.

2. It is influenced to a lesser extent by variation of the flow profile (Heberer 1985).

\subsubsection{Implantation of flowprobes, measurement, and calculations.}

Flowprobes were inserted in piglets $(20 \pm 0.8 \mathrm{~kg})$, using the same techniques as for catheter implantation. For the portal flow, probes of 8 to $12 \mathrm{~mm}$ (Skalar", Delft, The Netherlands) were used. For the measurement of small bowel flow, probes of suitable size were mounted on the superior mesenteric artery and colonic artery. For the large bowel flow was measured by flowprobes around the colonic artery and inferior mesenteric artery. Reliable electromagnetic llowmeasurements demand a good vessel fit (Charbon 1981). In the chronic situation the reduction in diameter should not exceed $10 \%$ to avoid changes in vessel walls resulting in rupture. To ascertain a perpendicular fit to the vessel wall a silicon wing was attached that could be fastened with a few stitches to the tissue around the vessel. Furthermore at least one week was allowed before measurement to allow fibrin to overly the probe, minimizing the risk of errors in measurement due to changes in position (Rerat 1983). The unavoidable drift of the zero baseline requires repeated resetting of this zero point. In our model this was carried out by implanting an insufflatable balloon at a distance of $1 \mathrm{~cm}$ distal from the flowprobe. Another concern was the reaction to the chro- 
nically implanted probe resulting in changes in vessel wall thickness (Heberer 1985). Postmortem examinations were therefore performed to check for vessel and flowprobe condition. Problems with flow probe cables (breakage) were awoided by careful selection. Septic complications as a result of the various catheters in our model forced us to withdraw some animals from the studies as in metabolic studies interference with antibiotics may be a problem. Nonseptic complications, ileus, thrombosis, as a result of the tortuous course of the implants in the abdomen, were minimized by shortening the intraabdominal route. As it could be expected that the more material was inserted the more trouble had to be faced, we chose for practical reasons separate groups of pigs for the flow measurements. Flow measurements were performed under the same conditions as for the group of pigs used for the determination of substrate concentrations. After an overnight fast zero flow was determined by insufflating the balloon. The flow measurements were started after a recovery of half an hour following various meals (pigfood, blood constituents, pigfood after one week of lactulose treatment, and pigfood after one week of neomycin treatment) over a period of 6 hours. The pulsatile flow signals were recorded on a penwriter (Kipp). After six hours the flowmeters were recalibrated to account for electronic drift. In our in vivo design, the position of the animal (lying, sitting, standing) resulted in fluctuations in time of about $20 \%$. These could not be differentiated from the effects of feeding and give rise to problems in calculations. For the calculations of the portal flow, mean flow was taken over the six hours period of ten piglets, taking at least two measurements under the same conditions at each time point, expressed as mean $\pm \mathrm{sem}$ in $\mathrm{ml} / \mathrm{min} / \mathrm{kg}$. For the small bowell flow the mean value of three piglets was calculated as the difference between superior mesenteric artery and colonic artery. Large bowel flow was calculated as the sum of mean inferior mesenteric artery and mean colonic artery flow, for the same three animals. The results are summarized in table 1 .

portal small bowel large bowel

$\begin{array}{lrrrr}\text { pigfood } & 44.3 \pm 2.4 & 18.5 \pm 1.0 & 7.9 \pm 0.7 & \mathrm{ml} / \mathrm{min} / \mathrm{kg} \\ \text { blood } & 39.5 \pm 1.6 & 19.7 \pm 1.0 & 7.7 \pm 0.7 & \mathrm{ml} / \mathrm{min} / \mathrm{kg} \\ \text { lactulose } & 41.0 \pm 4.0 & 19.0 \pm 1.0 & - & \mathrm{ml} / \mathrm{min} / \mathrm{kg} \\ \text { neomycin } & 43.0 \pm 4.0 & 20.0 \pm 1.0 & - & \mathrm{ml} / \mathrm{min} / \mathrm{kg}\end{array}$

Table 1. Fow in $\mathrm{ml} / \mathrm{min} / \mathrm{kg}$ (mean $\pm \operatorname{sem})$. 


\subsection{FULLY AUTOMATED DETERMINATION OF AMINO ACIDS BY HIGH PERFORMANCE LIQUTD CHROMATOGRAPHY."}

\subsubsection{Abstract.}

A cheap method for fully automated amino acid analysis is described, which combines the advantages of automated precolumn o-pthalaldehyde derivatization (OPA) with favorable analytical conditions to separate 30 normal plasma amino acids. The system can run unattended for almost four days, while data are processed automatically by a personal computer. During these four days, a maximum of 76 samples and 19 standards can be processed (cycle-time per analysis 55 minutes). Per analysis only $1 \mu \mathrm{l}$ of deproteinized plasma is required. Coefficients of variation for all relevant amino acids are better than $1 \%$ and $3 \%$ for retention times and areas measured respectively. The system described is well suited for rapid, sensitive and routine operation.

\subsubsection{Introduction.}

Metabolic or clinical studies requiring multiple amino acid analyses are generally hindered by the fact that amino acid determinations are relatively expensive and time consuming. Many methods have been described to determine amino acids in biological samples using o-pthalaldehyde precolumn derivatization followed by high performance liquid chromatography (Godell 1984; Smith 1985; Pfeifer 1983; Graser 1985; Hill 1979; Cloete 1984; Jones 1981; Abecassis 1985; Lindroth 1979; Fleury 1983). None however, combines a satisfactory separation of as many as 30 amino acids, including all important plasma amino acids, with a fully automated precolumn derivatization and automated data analysis. We describe a system that can run unattended for 87 hours. During this period 76 samples and 19 standards are processed.

\subsubsection{Materials and methods.}

\subsubsection{Equipment.}

A HPLC system was employed, consisting of 2 pumps (model 2152), a 2152 controller, a 2156 solvent conditioner and a 2155 column oven, all from LKB (Woerden, The Netherlands). Automated precolumn derivatization was performed with a WISP 712B sample processor (Millipore-Waters; Etten-Leur, The Netherlands), equipped with a cooled sample storage compartment. Fluorescence was monitored with a F1000 (Merck/Hitachi; Amsterdam, The Netherllands) fluorescence detector equipped with a xenon lamp and a $12 \mu \mathrm{l}$ flowcell. Measurements were made at an excitation wavelength of $330 \mathrm{~mm}$ and an emission

${ }^{1}$ H.M.H van Eijk, M.A.H. van der Heijden, C.L.H. van Berto, P.B. Soeters. Clin. Chem., 1988, accepted for publication. 
wavelength of $445 \mathrm{~nm}$. Data were collected on-line by a $763 \mathrm{SB} 192 \mathrm{~K}$ interface (Nelson Analytical; CLI, Schijndel, The Netherlands) and processed by an Olivetti M24SP personal computer (Woltink; Kerkrade, The Netherlands) running on Nelson Analytical software. The separation was carried out on a Spherisorb ODS II column, $3 \mu \mathrm{m}, 250 \times 4.6 \mathrm{~mm}$, equipped with a $10 \times 4.6 \mathrm{~mm}$ guard column filled with the same packing material (Salm \& Kipp; Breukelen, The Netherlands).

\subsubsection{Reagents and solvents.}

Ultra pure water was generated by a Milli-Q system (Millipore-Waters). All chemicals used were of analytical grade, solvents of chromatographic grade. OPhtaldialdehyde (OPA) reagent was prepared by dissolving $12.5 \mathrm{mg}$ OPA (Pierce; Oud Beijerland, The Netherlands) in $0.25 \mathrm{ml}$ methanol (Merck; Amsterdam, The Netherlands), adding $2.25 \mathrm{ml}$ borate buffer $(1.0 \mathrm{M}$ potassium borate, pH 10.4; Pierce) and $10 \mu \mathrm{l}$-mercapto-propionic acid (3 MPA; Fluka). Solvent $\mathrm{A}$ was a $12.5 \mathrm{mM}$ phosphate buffer $\mathrm{pH} 7.0$, containing $0.9 \%$ tetra hydro furan (THF; Merck). Solvent B consisted of $53 \%$ phosphate buffer, $40 \%$ acetonitril (Merck) and 7\% THF. Amino acid standards were prepared by dissolving pure chemicals (Pierce) in water to a final concentration of $250 \mu \mathrm{M}$ for each component and calibrated against commercial PAN (acidic and neutral amino acids) and PB (basic amino acids) standards (Pierce) on a 4400 amino acid analyzer (LKB) operated with lithium buffers in a $21 / 2$ hour physiological run.

\subsubsection{Sample preparation.}

Heparinized bloodsamples were immediately centrifuged at $3000 \mathrm{rpm}$. in a Sorvall GLC-2 centrifuge for 10 minutes at $4^{\circ} \mathrm{C}$. Plasma was deproteinized with sulfosalicylic acid (SSA; BDH; Brunschwig, Amsterdam, The Netherlands), 4 $\mathrm{mg} / 100 \mu \mathrm{l}$ plasma and centrifuged for ten minutes (10000 rpm) in an Eppendorf 5414 centrigufe at $4^{\circ} \mathrm{C}$. Samples and standards were stored at $-70^{\circ} \mathrm{C}$ and prior to analysis diluted $1: 100$.

\subsubsection{Chromatographic conditions}

During the first 4.6 minutes of the run, the automated precolumn derivatization is executed by the sampleprocessor. The sampler takes first $5 \mu$ l of the OPA reagent and injects it into its sampleloop. Because flow is still zero, the OPA remains in the loop. At $t=1$ minute the sampler injects $5 \mu$ lof a sample into the loop. Hereafter the flow is slowly increased to $1.2 \mathrm{ml} / \mathrm{min}$. thus allowing sample and reagent to mix and react and the gradient starts (figure 1). Pressure is $2.20 \mathrm{MPcal}$. at the start of the gradient. After restoring initial conditions at the end of the run, flow is stopped and the next cycle can be started. The column is placed in an oven set at $22^{\circ} \mathrm{C}$, because some derivatives (e.g. histidine derivatives) are very temperature sensitive. 


\subsubsection{Data processing}

The analog signal produced by the fluorescence monitor is digitalized by a Nelson Analytical interface and sent to a disk-file from which the software produces a report. The retention times and response factors used for detection and calculation, are corrected after every 4 samples using an external standard method. The results are entered directly into a spreadsheet or other program, thus simplifying and speeding up data management.
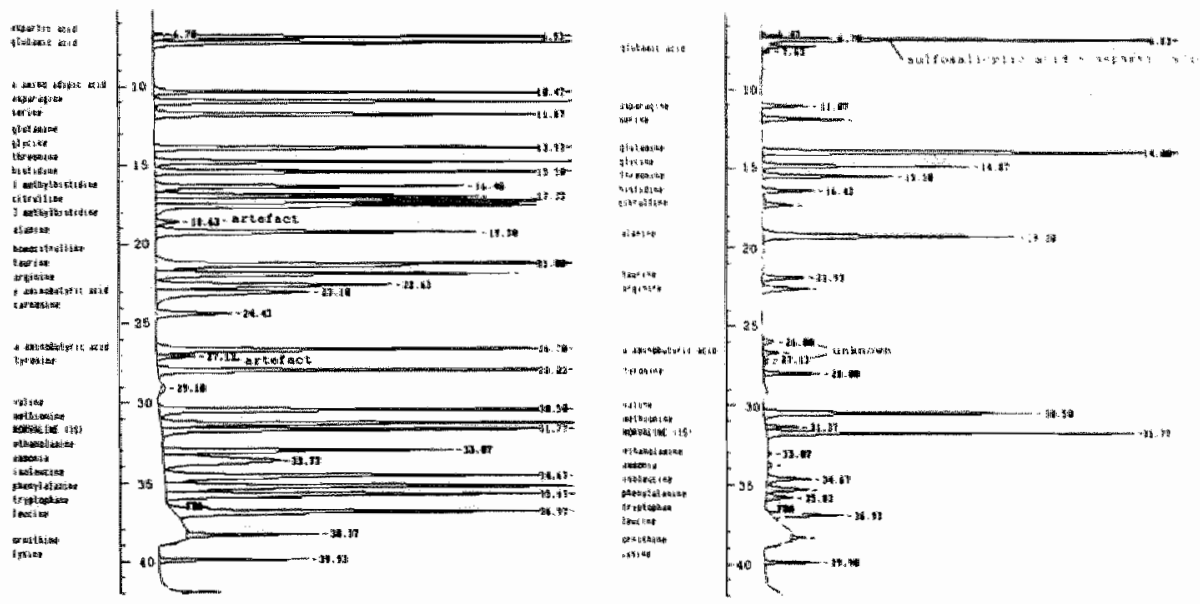

Figure 1. Separation of plasma amino acid stendard (Figure 1a) and a human plasma sample (figure 1b). Standard represents $25 \mathrm{pmol}$ of each amino acid. Solvent $A=12.5 \mathrm{mM}$ phosphate buffer, $\mathrm{pH}=7.00+0.9 \%$ THF. Solvent $\mathrm{B}=53 \%$ phosphate buffer, $\mathrm{pH}=7.00,12.5 \mathrm{mM}, 40 \%$ acetonitril and $7 \%$ THF. Column, Bisschoff Spherisorb ODS $I_{1}, 3 \mu M_{n} 250 \times 4.6 \mathrm{~mm}$, with a $10 \times 4.6$ mm guard column (same packing). Gradient: time $(\mathrm{t})=0$ (min.) flow $(\mathrm{F})=0(\mathrm{~m} / \mathrm{min}) \% \mathrm{~B}(\mathrm{~B})=$ $0 ; t=2.5 \quad P=0,02 \quad B=0 ; \quad t=2.7 \quad F=0.04 \quad B=0 ; t=3.0 \quad F=0.05 \quad B=0 ; t=3.5 \quad F=0.10 \quad B=0 ; t=4.5$ $P=0.60 \quad B=0 ; t=4.6 \quad P=1.20 \quad B=0 ;$ now now $(F)$ remains 1.20 ml/min until $t=54$ min.; $=8 \quad B=6$; $t=10 \quad B=8 ; t=13 \quad B=8 ; t=14 B=10 ; t=19 B=13 ; t=26 \quad B=28 ; t=31 \quad B=30 ; t=36 \quad B=40 ; t=39$ $B=100 ; t=41 \quad B=100 ; t=44 B=0 ; t=54 \quad P=0.60 \quad B=0 ; t=55 \quad \mathrm{P}=0 \quad B=0$.

\subsubsection{Results.}

We modified the solvents and gradient used by Godel et al (1984), to achieve a satisfactory separation of a physiological standard containing 30 amino acids, including tryptophan (figure 1). Furthermore, we adjusted the automated precolumn derivatization used by Smith et al (1985) and Pfeifer et al (1983), and combined it with the chromatographic separation already achieved. The combined method resulted in an excellent reproducibility of both retention times and measured areas for all amino acids measured (table 1). 
The cooled sample compartment of the autosampler can be loaded with sample trays containing 48 or 96 positions. As a consequence maximally 95 analyses ( 1 position is needed for the OPA-reagent), can be executed automatically and unattended.

No changes in amino acid concentrations were observed, when measuring aliquots of a human plasma stored in the cooled sample tray of the sampleprocessor, over a period of almost 4 days (Table 1 ).

Also, we determined normal plasma concentrations of 30 bealthy human volunteers, aged between 20 and 57 years (table 1), in the post absorptive and fed state (1 hour after a normal lunch). The values obtained corresponded well with the literature (Godel 1984).

Proline, hydroxyproline and cysteine could not be detected with the method described, and aspartic acid (ASP) co-eluted with sulfosalicylic acid (SSA) used for deproteinization.

Finally, the fluorescence response for all amino acids measured was investigated. A linear response was found over a range from 1.25 to $50 \mathrm{pmol} / 5 \mu \mathrm{l}$ injected (corresponding to plasma concentrations of $25-1000 \mu \mathrm{M}$ ).

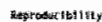

\begin{tabular}{|c|c|c|c|c|c|c|c|c|c|c|c|c|c|}
\hline \multirow[b]{3}{*}{ resegostatit } & \multicolumn{6}{|c|}{ 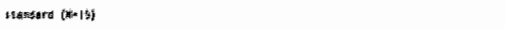 } & \multicolumn{3}{|c|}{$p$ tus $(k-40)$} & \multicolumn{4}{|c|}{ manes! whens } \\
\hline & \multicolumn{2}{|c|}{ 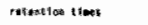 } & \multicolumn{3}{|c|}{ antes (1) } & \multicolumn{4}{|c|}{ concrestrat Heat } & \multicolumn{4}{|c|}{ 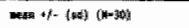 } \\
\hline & $\operatorname{man}$ & in & F. . & $\operatorname{man}$ & A. A:- & $E *$ & man & Mina. & t.4. & taustedi: & & tot & \\
\hline & $(\boldsymbol{*} \mid \mathbf{s})$ & $\left(\omega \mathbf{A}^{\prime}\right)$ & (4) & $\tan \theta t s$ & $\cos 281$ & not & win & mollo & (4) & andith. & & $p=s i d t$ & \\
\hline 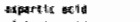 & 6. 64 & (日.) & 0.41 & 3.4 & 0.0 & $i \cdot$ ta & & & . & $\infty$ & - & - & \\
\hline olutimlif ecto & rng & a. & 0.35 & 2.00 & 0. & 1. & $\mathbf{p a}, \mathrm{a}$ & 1.0 & 18,0 & 粟 & (1) & $n$ & (15) \\
\hline 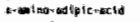 & 9150 & 0.40 & 0.91 & 3.4 & a & $1.7 \%$ & & & . & . & - & - & \\
\hline Aspareag inot & $\$ 11.00$ & 0.00 & 0.8 & 2. 5 & $0,0.3$ & 1.34 & 45 & $1 . \theta$ & 7.4 & 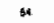 & \{国淂 & 烟 & (25:) \\
\hline serfatet & $\{4.85$ & 0.09 & 0.60 & 2.10 & 0.02 & itw: & liat at & 3.0 & 3.6 & 3 & $(19)$ & 9 & (asw \\
\hline 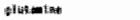 & (j). 35 & 0,0 & 0.64 & 2.42 & 0.0 & 1. & 640.4 & 10.0 & 2.0 & 50 & $100 \%$ & 519 & (1) \\
\hline Diverine & (6.). 13 & 0.06 & 0.42 & 2.18 & 0.04 & $\ln \%$ & 205 & 0.0 & 3.18 & 845 & $(54)$ & 25 & $(3 y)$ \\
\hline Anerofin' no & 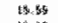 & 0.00 & 6.87 & 14.24 & 0,4 & 1. & 1.44 & $3 . \theta$ & 2.10 & 413 & 227 & 110 & $(w)$ \\
\hline 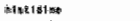 & 14.1 .3 & $0.9)$ & O. ali & $1,7 \mathrm{H}$ & 0. & 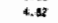 & 39.9 & 4.0 & 8.18 & 34 & ;09\} & sis & (1) \\
\hline 1. & $|6| 1 \mid$ & 0.00 & Q. 蕴 & t. 4.4 & 0.34 & $3, \sqrt{3}$ & - & . & - & - & & . & \\
\hline 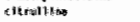 & 17.to & 0.0 & 0.45 & s" & 0 & $3.4 \times 1$ & 92, & 3.0 & 10.16 & 酞 & 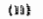 & $x$ & \{ \\
\hline 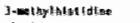 & $\mid r, 9\}$ & 0.01 & 0.4 & a.t. & Q. & c. 48 & . & 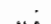 & 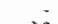 & . & $*$ & $=$ & \\
\hline 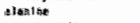 & IS! Iit' & 0.0. & 0.313 & 2.19 & 0.01 & 1. $y^{3}$ & 300 & n10 & 3,0 & 33* & $\left(n_{i}\right)$ & 436 & $\left\{w_{*}\right.$ \\
\hline 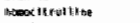 & 31.63 & 0.01 & 0.313 & 2. +16 & 0.118 & 4.1.8 & & & $\cdot$ & - & - & - & \\
\hline Thap 10ath & 21..9 & Q $\infty$ & $0,2 \%$ & an & 0.04 & 2. 19 & $\$ 6.0$ & 3.0 & 5.t. & IN & $(\Delta))$ & 36 & 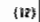 \\
\hline Arela & 32.57 & 0.07 & o. 精 & 1.54 & 0.11 & 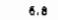 & सक्स & 6.0 & $r .0$ & ss & (뎍 & 106 & (1) \\
\hline 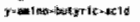 & $\pi \infty$ & $0 . \infty$ & 0.踏 & A.is & a.ak & $1 . \%$ & . & - & $\cdots$ & " & . & 。 & \\
\hline cariagy tase & $7+8 \%$ & 0.37 & 0.27 & Q.! in & 0.011 & 0.04 & - & - & - & - & - & . & \\
\hline 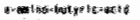 & (2) & 10.34 & 0.10 & 2.69 & Q.0.1 & 了針 & 19.0 & $1, \theta$ & t. & 喓 & 眻 & 90 & (6) \\
\hline Iywosing & n睡 & $0.9 j$ & 0,11 & *ै. & 0. & $8: 10$ & $\mathbf{8 3 . 0 !}$ & 1.8 & 2.8 & 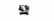 & 164 & 6 & (1) \\
\hline TEl I & bo & 10. $\Delta$ & to. & 2. & $6.1 !$ & 4.45 & 204.0 & 3.0 & 20 & स & 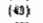 & 314 & ix \\
\hline maliticaline & $31.5 \%$ & 6.53 & 0,0 & 2.800 & 0.4 & $\ln x^{3}$ & 83.0 & 1.8 & 2.07 & 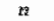 & f.5. & 26 & $m$ \\
\hline What wh (as) & I1. 哂 & 0.94 & 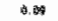 & D. & Q. & in & " & . & - & - & . & . & \\
\hline 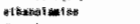 & 30.00 & 0,60 & 0.18 & 1. & ᄈै. 11 & 1., & . & . & - & . & - & - & \\
\hline as & 31 & 9.96 & ais & & . & x & . & . & - & . & - & . & \\
\hline 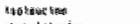 & His & 0 & 0.80 & स. W.: & then & 1. 5 & 91.0 & 1.0 & 7..97 & th & : 1:3!i: & 80 & (16) \\
\hline 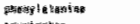 & 36,63 & 4.68 & 0.8 .4 & 8.41 & (9.69. & $9 h$ & a. & 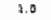 & 3. & as & (n) & 60 & (iii) \\
\hline 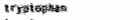 & 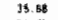 & 0.44 & a.4 & 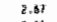 & (ton & A. A. $\mathrm{s}$ & 33.6. & 1.0 & 1.6 & . & - & . & \\
\hline Aper the & 16. 13 & 细 & $3: 0$ & 贵绩 & 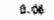 & 230 & 30 & 3.8 & 4.1. & hie & 1964 & my & [76, \\
\hline arsistiany & It 1.8 & a. hy & 0.2 .2 & 0. 组! & W & 3.36 & 45.0 & 1.0 & 3. & 5 & (n) & ro & 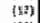 \\
\hline byalisis & 76 & 日，琎 & 0.80 & 0.31 & 9.64 & 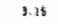 & its. & 1.0 & y. & 108 & 105 & 湤 & (1) \\
\hline
\end{tabular}

Table 1. Reproducibility of retention times and measured areas of standards $(N=15)$. Stability of reagent and plasma amino acids upon storage in the sample processor $(\mathrm{N}=80)$. Nomal plasman amino acid concentrations of human volunteers (aged between 20 and 57 years) in the post-absorptive and fied state. 


\subsubsection{Discussion.}

In our laboratory, we needed a fast and reliable method for the determination of all plasma amino acids to perform clinical and metabolic studies (Vente 1986; Van Berlo 1987; Van Leeuwen 1988). In the literature, many HPLC methods have been described using pre or post column derivatization techniques (Godel 1984; Smith 1985, Pfeifer 1983; Graser 1985; Hill 1979, 1982; Cloete 1984; Jones 1981; Abecassis 1985; Lindroth 1979; Fleury 1983; Einarsson 1983; Betner 1986; Heinrikson 1984). From these, the o-phtaldialdehyde (OPA) precolumn derivatization technique has several advantages, such as a relatively simple derivatization procedure and great sensitivity, when compared with other techniques (FMOC: 9-fluorenylmethyloxycarbonchloride (Einarsson 1983; Betner 1986), PITC: phenylisothiocyanate (Heinrikson 1984)). As the fluorescent response of each derivative is dependent on the reaction time with OPA, automated precolumn derivatization will improve reproducibility of the method. We found only a few publications (Smith 1985; Pfeifer 1983; Cloete 1984; Fleury 1983) describing an automated procedure. However, these methods suffered, either from a poor separation of some important amino acids, or long cycle times per analysis.

Combining and optimizing these methods, we developed an automated chromatographic system, which is able to process one sample each 55 minutes, without operator interference for almost 4 days. Thirty plasma amino acids are separated, while only $1 \mu$ l of deproteinized sample per analysis was needed. The method allows good reproducibility for both retention times as well as peak area measurement within one batch of analyses (better than $1 \%$ respectively $3 \%$ for most amino acids). However, between batches retention times may differ more (1-5\%), due to slight variations in solvent content. When using a new column, it may be necessary to adjust the amount of THF in solvent $A$ for optimum separation. Although the system can run unattended for 4 days, 2 problems may arise. From the literature (Godel 1984; Graser 1985) it is known, that the OPA-reagent deteriorates slowly in time as the $3 \mathrm{MPA}$ evaporates. Furthermore, some amino acids (e.g. glutamine, asparagine) degrade spontaneously at a rate which depends among other factors on the temperature of the solution. The first problem has been overcome by storing the reagent in a sample vial with a self-sealing cap (Betron Scientific). The second problem was solved by cooling the sample-compartment of the autosampler to $4^{\circ} \mathrm{C}$. Sample and reagent stability were tested by processing 80 aliquots of a diluted human plasma, stored in the sampleprocessor for 3 and a half days, using the same OPA-reagent. During this period, we did not observe any change in amino acid concentrations measured (table 1). A linear response for plasma concentrations ranging from at least 25 to $1000 \mu \mathrm{mol} / \mathrm{L}$ was found (1.25 to $50 \mathrm{pmol}$ injected). Chromatographic reports, produced by the software are stored on disk. These reports, which are generally the end result of automated data processing in the literature, are then imported in a spreadsheet or a statistics program, thus accelerating evaluation of the analytical results drastically. 
When comparing this method with conventional amino acid analysis, the following conclusions can be drawn:

1) Analysis time and reagent costs of the HPLC-method are roughly onethird of conventional amino acid analysis in our laboratory.

2) Only very small sample amounts $(1 \mu \mathrm{l})$ are required for analysis.

3) The use of automated sample-processing minimizes operators interference and improves reproducibility of the method.

4) The interpretation of analytical results is accelerated substantially when analysis is combined with automated data management.

5) Proline, hydroxyprolline, cysteine could not be detected with the method described, while in plasma aspartic acid coelutes with the sulfosalicylic acid used for deproteinization. 


\subsection{THE DETERMINATION OF AMMONIA IN PLASMA AND WHOLE BLOOD.}

\subsubsection{Abstract.}

The three techniques most commonly used to measure plasma and whole blood ammonia are the microdiffusion method with the ammonia checker system (ACS), the ion exchange method and the enzymatic method. We reviewed the literature and carried out studies to evaluate these techniques with regard to:

1. The correlation between ammonia levels in plasma and whole blood specifically in states of hyperammonemia;

2. The recovery of ammonia after addition of ammonium salts to whole blood;

3. The influence of potential inhibitors on ammonia determination;

4. Specimen stability after freezing.

Our studies revealed good correlation coefficients between measurement of ammonia in whole blood and plasma with both the ACS and ion exchange method. When ammonium salts were added to whole blood or plasma complete recovery $(100 \%)$ was found unless ammonium salt was added in the dry form (70\%). Lactulose and neomycin did not interfere with the enzymatic method, while ion exchange values were significantly decreased. Plasma ammonia concentrations are not affected by long term storage ( 3 months) when samples are kept at $-70^{\circ} \mathrm{C}$.

\subsubsection{Introduction.}

Although much work has been done concerning the determination of ammonia in plasma and whole blood, there is still no complete agreement as to what technique is most appropriate in different situations. The purpose of this agreement is to try to clarify the discrepancies in the present literature. The following aspects were investigated:

1. To determine if differences exist in ammonia content in plasma and whole blood, specifically in situations where high ammonia levels can be expected such as in portal blood or in blood from animals with porta-caval shunts or hepatic failure.

2. To study the percentage recovery following addition of ammonia salts to whole blood or plasma.

3. To determine if neomycin and lactulose interfere with the determination.

4. To study the effects of freezing, thawing and storage on the enzymatic technique.

M.A. Janssen, C.L.H. wan Berlo, P.A.M. van lecuwen, P.B. Soeters.In: Advances in Ammonia Metabolism and Hepatic Encephalopathy, 1988; Chapter 76: 587. 


\subsubsection{Materials and methods.}

\subsubsection{Animals.}

Malle Wistar rats $(200 \pm 20 \mathrm{~g})$ fed regular laboratory diet (Hope Farms SRM-A120, Woerden, The Netherlands) and water ad libitum were used.

\subsubsection{Surgical procedures.}

Blood was sampled from unoperated control rats, rats with porta-caval shunts and rats with acute liver failure induced by galactosamine. End-to-side portacaval shunts (PCS) were performed under ether anesthesia, employing a modified suture technique (Funovics 1975). Blood was sampled one week following surgery. Acute liver failure resulted $18 \mathrm{~h}$ after injection of $4.25 \mathrm{mmol}$ galactosamine/kg body weight. Blood samples were taken $24 \mathrm{~h}$ after injection.

\subsubsection{Blood sampling.}

After an overnight fast the abdomen was opened under light ether anesthesia and blood was sampled from the portal vein. Heparinized blood was collected on ice and plasma was separated after centrifugation for $10 \mathrm{~min}$ at $1500 \times \mathrm{g}$ at $4^{\circ} \mathrm{C}$. Analysis was carried out within $30 \mathrm{~min}$ after collection. One part of the plasma was frozen immediately in liquid nitrogen and stored at $-70^{\circ} \mathrm{C}$ for later determination. Frozen samples were thawed $3 \mathrm{~min}$ at $38^{\circ} \mathrm{C}$ (Conn 1964), cooled on ice and determined immediately.

\subsubsection{Ammonia determination.}

Ammonia was determined in plasma and whole blood employing three different techniques.

1. The ion-exchange method as described by Kingsley and Tager, followed by the Berthelot color reaction (Kingsley 1970);

2. Reflectometer - the ammonia checker system (ACS) combines a reflectometer, allowing direct read-out of blood or plasma ammonia concentration with a special blood ammonia test kit (Oberholzer 1976; Leweling 1983; Ratnaike 1982);

3. Quantitative automatic enzymatic plasma ammonia determination was performed with a Sigma test kit No. 170-UV on a centrifugal analyzer system (Cobas Bio, Roche ${ }^{\mathfrak{k}}$ Diagnostica) (DaFonseca Wollheim 1973; Van Anken 1974).

\subsubsection{Results.}

\subsubsection{Recovery in whole blood.}


$100 \mu$ l Human whole blood were mixed with $100 \mu \mathrm{l} 100 \mu \mathrm{M}$ standard ammonia dissolved in $0.9 \% \mathrm{NaCl}$ or distilled water. A further $1.9 \mathrm{ml}$ blood was mixed with $100 \mu \mathrm{l} 1 \mathrm{mM}$ standard. Ammonia determinations were performed with the ACS. The recovery found for human whole blood mixed (1:1) with ammonia dissolved in $0.9 \% \mathrm{NaCl}$ or distilled water was $100 \%$. For a lower dilution (1.20) a recovery of only $82 \%$ was found.

\subsubsection{Influences of freezing and thawing.}

Freshly pooled plasma was analyzed with the enzymatic method. 110 Samples were taken from one pool. Ten samples were examined at time 0 and ten at $30 \mathrm{~min}$ (stored at $4^{\circ} \mathrm{C}$ ). The other 90 samples were frozen and examined after 1,2 and 3 days and $1,2,3,4,8$, and 12 weeks. For the directly measured pooled plasma a value of $57 \mu \mathrm{M}$ with a coefficient of variation of $4.5 \%$ was obtained. After freezing a mean value of $60 \mu \mathrm{M}$ (range $55-64 \mu \mathrm{M}$, c.v. $\pm 4.5 \%$ ) was obtained.

\subsubsection{Plasma/whole blood ratio.}

Plasma and whole blood ratios were analyzed by ion-exchange and ACS methods immediately after portal blood sampling from porta-caval shunted rats, galactosamine treated rats and control animals, and results are presented in figure 1. The cation exchange and ACS plasma/whole blood ratio showed good comparability (correlation coefficient 0.967 , slope 1.11 , and correlation coefficient 0.997 , slope 1.04 , respectively). No significant differences were observed between whole blood and plasma ammonia concentrations in porta-caval shumted rats, in acute liver failure and in controls.

\subsubsection{The influence of lactulose and neomycin on ammonia determination.}

Analysis was performed with the ion-exchange and enzymatic methods. Ammonia analysis was examined in $300 \mu \mathrm{M}$ standard solution mixed with increasing concentrations (0-25\%) lactulose (Duphalac ${ }^{\mathbb{R}}$ Duphar), saccharose, lactose, glucose, fructose and galactose. The same was done for $300 \mu \mathrm{M}$ ammonia standard solutions mixed with increasing concentrations of neomycin $(2.5 .25 \mathrm{mg} / \mathrm{ml}$, Lundbeck). No disturbances were found with the enzymatic method, in contrast to the ion-exchange method where inhibition was found for lactulose, neomycin and the different sugars at all the concentrations used.

\subsubsection{Discussion.}

The microdiffusion method of Conway (Conn 1964; Seligson 1957) involves alkalinization of blood to convert ammonium to diffusible gaseous ammonia. The problem of falsely high values of ammonia is well recognized. Ammonia concentrations found in plasma were lower $(58 \%)$ compared to whole blood (Seligson 1957). Therefore this method has been replaced by other methods involving the use of cation-exchange resins or glutamate dehydrogenase (EC 1.4.1.3), 
or the more recently developed ammonia checker system. Lower normal values of plasma and whole blood were obtained with the ion-exchange, enzymatic and checker system, compared to the microdiffusion method (DaFonseca Wollheim 1973; Seligson 1957; Hutchinson 1962; Mondzac 1965; Huizinga 1983; Murawaki 1984; Ratnaike 1984; Van Anken 1974). However, the ratio whole blood/plasma ammonia concentration as reported by Seligson and Hirahara (1957) (microdiffusion method) is still cited. Since 1978 correlation studies between ammonia concentrations in plasma and whole blood have been undertaken employing different methods (Huizinga 1983; Murawaki 1984; Ratnaike 1984; Oberholzer 1976). In general there is good agreement between the three different methods with coefficients of correlation around 1.0 and slopes varying between 0.835 and 1.1. The coefficient of variation for the checker method (8\%) and ion-exchange is higher than for the enzymatic method (4\%). These results are comparable with those from the literature (Tada 1979; Murawaki 1984; Ratnaike 1984). It would appear therefore that the differences reported in the literature for 'normal values' before 1978 may be artifactial. Many investigators have shown that the enzymatic determination of ammonia is to be preferred because it is specific, simple and rapid (Van Anken 1974). Conflicting results have been reported in the literature for plasma whole blood ratios in cirrhotic patients (Murawaki 1984; Ratnaike 1982, 1984; Leweling 1983). Ratnaike et al. (1982) reported differences in plasma whole blood ratios during portal systemic encephallopathy, making the determination of erythrocyte ammonia valuable. Our studies (figure 1) employing two different analytical methods in two different liver failure models did not reveal differences in any instance. These data are consistent with the results reported by several clinical investigators (Murawaki 1984; Ratnaike 1984; Leweling 1983). As differences in recovery can be caused by the way in which ammonia is added to freshly sampled blood (dry, in $0.9 \% \mathrm{NaCl}$, distilled water or Preciset Boehringer standard ammonium solution) recovery studies were undertaken with the checker method. Only when ammonium is added in dry form to whole blood incomplete recovery is found. This is in agreement with the literature, where $100 \%$ recovery is generally found (Tada 1979; Murawaki 1984) unless ammonia is added in dry form (Hutchinson 1962; Huizinga 1983). The influence of temperature on in vitro generation of ammonia in plasma and whole blood has been studied previously (Conn 1964; Oberholzer 1976; Gips 1968; Von Wahdati 1979; Prellwitz 1976). The longest stable period reported at $-20^{\circ} \mathrm{C}$ and $-70^{\circ} \mathrm{C}$ was 2-8 days (Lowe 1968). The number of samples and coefficient of variation was not reported. Intra-assay variation after freezing and thawing varies from 3.9 to $5.7 \%$ over a 3-month period. No lloss or increase of ammonia occurred. This allows large scale studies to be carried out in a short period and determination at a convenient time. The influence of lactulose and neomycin on the ammonia determination with the cation-exchange and enzymatic methods has not been studied previously. Both lactulose and neomycin exert an inhibitory effect on the cation-exchange method, in contrast to the enzymatic method. Inhibition was also found with other reducing sugars, which could explain the disturbances caused by lactulose on the Berthelot reaction. 
CATION-EXCHANGE

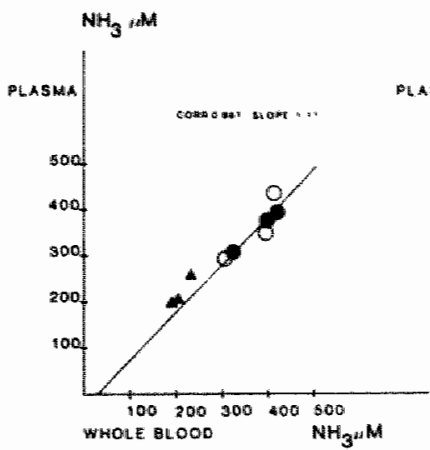

CHECKER

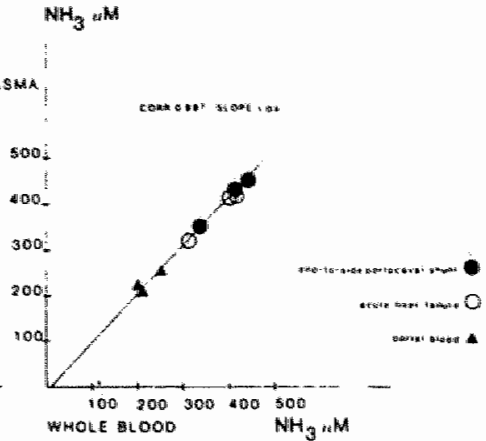

Figure 1 High plasma whole blood ammonia concentrations in the three different rat models with the cation-exchange and checker method. 


\section{CHAPTER 3.1.}

IS INCREASED AMMONIA LIBERATION AFTER BLEEDING IN THE DIGESTIVE TRACT THE CONSEOUENCE OF COMPLETE ABSENCE OF ISOLEUCINE IN HEMOGLOBIN? A STUDY IN PIGS."

\subsubsection{Abstract.}

A hierarchy in protein induced toxicity has been reported in liver disease. The aim of this study was to establish the cause of increased ammonia liberation in the gut after intraluminal bleeding. Therefore blood was sampled from catheterized piglets $(20 \pm 0.8 \mathrm{~kg}$ (mean $\pm \mathrm{sem}$ ); $\mathrm{n}=10$ ) to determine ammonia, urea and amino acid levels before, one, two, three, and six hours after a standard pig meal $(750 \mathrm{~g}, 12 \%$ protein). After a week this procedure was repeated after ingestion of an isonitrogenous amount of bovine whole blood $(400 \mathrm{ml})$. In a second series of experiments the same procedures were performed after ingestion of plasma, whole blood, erythrocytes and food. Electromagnetically measured total intestinal, small, and large bowel flow was not significantly influenced by the type of meal ingested. Portal ammonia release was significantly increased twofold after a blood meal, whille intestinal glutamine utilization did not increase. Plasma urea levels were increased $200-300 \%$ after whole blood and erythrocytes, while after ingestion of plasma, urea levels were similar to values in controls. Glutamine utilization was not different among the various groups and occurred predominantly in the small bowel. In the fasted state small bowel glutamine utilization parallelled ammonia production. In the fed state this equimolar relationship could not be assessed because luminal glutamine utilization could not be determined. Isoleucine levels decreased to $25 \%$ of fasting levels. Analysis of blood constituents revealed a complete lack of isoleucine in the hemoglobin molecule. Net total $\alpha$-amino-nitrogen absorption was doubled after a blood meal. The highest absorption levels were found in the small bowel. These findings lead us to hypothesize that due to complete lack of isoleucine in hemoglobin, ingestion of blood into the gut presents the organism with protein of low biological value, leading to decreased protein synthesis and to net protein degradation, which in turn may result in increased ammonia- and ureagenesis.

\subsubsection{Introduction.}

1 C.L.H. van Berlo, A.E.J.M. van den Bogaard, M.A.H. van der Heijden, H.M.H. van Bijk, M.A. Janssen, M.C.F. Bost, P.B. Soeters. In: Advances in Ammonia Metabolism and Hepatic Encephalopathy, 1988, Chapter 18; 154. Hepatology, 1988, in press. 
Gastrointestinal bleeding is known to induce profound malaise and a negative nitrogen balance, which in liver patients gives rise to high plasma ammonia levels and precipitates hepatic encephalopathy (McDermott 1954; Mutchnick 1974; Gaustad 1949; Summerskill 1957; Welch 1956; Faloon 1970). A hierarchy in the degree of toxicity of different types of orally ingested protein has been reported in patients at risk for hepatic encephalopathy. Gram for gram, blood appears to be more toxic than meat, which in turn appears to be more toxic than dairy or vegetable protein (Greenberger 1977; De Bruijn 1983; Uribe 1982, 1985; Keshavarzian 1984; Young 1957; Bessman 1958, 1963). Many explanations have been offered for these differences in coma-inducing potential, including differing sites of degradation and different content of free ammonia and amino acids (Conn 1979; Rudman 1973; Greenstein 1956). In order to investigate increased ammonia production reported after gastrointestinal bleeding we used the pig as a model. Assuming that protein content and composition of blood protein are crucial factors determining the toxicity of blood we calculated and measured the free and total amino acid content of blood. In an in vivo model we studied the fate of blood after absorption. To investigate which constituent of blood was the determining factor a second series of experiments was performed with isonitrogenous and isocaloric amounts of plasma, erythrocytes, and whole blood.

\subsubsection{Materials and methods.}

\subsubsection{Animals.}

Female crossbred (Yorkshire $x$ Dutch Landrace) piglets $(20 \pm 0.8 \mathrm{~kg} ; \mathrm{n}=10)$ were used and individually housed in galvanized bar runs ( $2 \times 3$ meters) equipped with an automatic watering device. Animals were placed in the pen and acclimatized to their new surroundings for at least three days before surgery. In this period they got acquainted to the investigator and to a small movable cage $(0.9 \times 0.5 \times 0.3 \mathrm{~m})$ used during blood sampling. During the whole period animals were treated according to the guidelines of the European convention for the protection of vertebrate animals used for experimental and other scientific purposes.

\subsubsection{Surgical procedures.}

Animals were fasted for 24 hours. Half an hour after premedication (azaperon $8 \mathrm{mg} / \mathrm{kg}$, ketamine $\mathrm{HCl} 10 \mathrm{mg} / \mathrm{kg}$ ) anesthesia was induced with thiopental sodium $(25 \mathrm{mg} / \mathrm{kg})$ via an ear vein. Anesthesia was maintained with a nitrousoxide, oxygen (1:2), halothane (0.8\%) mixture. Lactated Ringer's solution (500-1000ml) was given during operation. Via the ear vein ampicillin $(25 \mathrm{mg} / \mathrm{kg})$ was given as antimicrobial prophylaxis (Van den Bogaard 1985). The neck, thorax, and abdomen were prepared for aseptic surgery. Catheters were inserted in the carotid artery, the portal vein, the superior mesenteric vein and the colonic vein and passed subcutaneously to the animal's back where the free ends lay behind the scapula. The outer end was not fixed to the skin, allowing the catheter to 
be gradually pulled through the skin with growth. Postoperatively the animals were placed in isolated heated cages to prevent chilling. The catheters were filled with heparinized saline, refreshed after blood sampling or twice a week. No other anticoagulant medication was given. The pigs received a canvas harness to protect the catheters, and to allow easier handling of the animals. In a separate group of pigs $(n=10)$ only carotid artery and portal vein catheters were inserted, while electromagnetic flowprobes (Skalar ${ }^{p}$, Delft, The Netherlands) and insufflatable balloons were mounted on the portal vein, enabling mean portal flow measurements (Rerat 1971). In another group $(\mathrm{n}=3$ ) only small bowel (superior mesenteric artery minus colonic artery) and large bowel (collonic artery plus inferior mesenteric artery) flow measurements were performed (Charbon 1981).

\subsubsection{Experiments.}

All operations were performed at least one week prior to experimentation. In the first series of experiments the pigs were starved for 16 hours. Blood was sampled from the various catheter sites for determination of ammonia, urea, and amino acids before, and one, two, three, and six hours after a standard pigmeal $(750 \mathrm{~g}, 12 \%$ protein, $370 \mathrm{KJ})$. One week later an isonitrogenous bloodmeal $(400 \mathrm{ml},<5 \mathrm{~kJ})$ was given in stead of the standard pigmeal (table 1 ). In the second series of experiments isonitrogenous but hypocaloric amounts of erythrocytes $(125 \mathrm{ml},<5 \mathrm{KJ})$, whole blood $(192 \mathrm{ml},<5 \mathrm{KJ})$ and plasma ( $400 \mathrm{ml},<5 \mathrm{KJ}$ ) were compared with standard pig food $(210 \mathrm{~g}, 12 \%$ protein, $104 \mathrm{KJ}$ ). Flow measurements were performed on various days with different meals in the conscious, unrestrained, conditioned animals. In all experiments animals served as their own controls.

\subsubsection{Analyses.}

Blood samples were immediately put on ice and transferred to the laboratory. After hematocrit determination the heparinized blood was centrifuged for ten minutes at four degrees centigrade. Plasma was frozen to $-70^{\circ} \mathrm{C}$ until determination of ammonia, urea and aminograms. Ammonia was determined with an automated (Cobas-Bio, Roche ${ }^{\text {P) }}$ enzymatic method (Sigma Ammonia Kit) according to DaFonseca Wollheim (DaFonseca Wollheim 1974; Janssen 1987, 1988). Urea and amino acids were determined with an automated amino acid analyzer (LKB 4400), using lithium buffers, or with a HPLC employing opthaldialdehyde precolumn derivatization (Andrews 1987; Godel 1984).

\subsubsection{Calculation and statistics.}

The production or utilization of substrates across an organ can be calculated by multiplying the concentration difference across that organ and organ blood flow. For the whole intestine porta-arterial difference was multiplied with the mean flow through the portal vein as derived from the separate group of pigs. For the small bowel the difference in concentration between superior mesente- 
ric vein and arterial blood was multiplied with the mean flow derived by subtracting colonic artery flow from superior mesenteric artery flow. The large bowel production was the product of the difference in concentration between colonic vein and arterial blood and mean flow to the large bowel (inferior mesenteric artery plus colonic artery). Statistical analyses comprised mean, sem and comparison of two groups by t-test (experiment 1) or paired Wilcoxon test (experiment 2). The level of significance was set at the $p=0.05$ level unless otherwise stated.

\subsubsection{Results.}

\subsubsection{Blood flow rates.}

The mean portal blood flow rate during the postprandial period was not significantly influenced by food intake or type of regimen (pigfood: $44.3 \pm 2.4$ $\mathrm{ml} / \mathrm{min} / \mathrm{kg}$; blood constituents: $39.5 \pm 1.6 \mathrm{ml} / \mathrm{min} / \mathrm{kg} ; \mathrm{n}=10$ ). The same was concluded for the mean small bowel flow, derived from mean mesenteric artery minus mean colonic artery flow (pigfood: $18.5 \pm 1 \mathrm{ml} / \mathrm{min} / \mathrm{kg}$; blood constituents: $19.7 \pm 1 \mathrm{ml} / \mathrm{min} / \mathrm{kg} ; \mathrm{n}=3$ ) and the mean large bowel flow, calculated as the sum of the mean colonic artery and inferior mesenteric artery flow (pigfood: $7.9 \pm 0.7 \mathrm{ml} / \mathrm{min} / \mathrm{kg}$; blood constituents: $7.7 \pm 0.7 \mathrm{ml} / \mathrm{min} / \mathrm{kg} ; \mathrm{n}=3$ ).

\subsubsection{Ammonia levels (figure Ia, table 2).}

Interassay variations, presented as coefficients of variation, expressed as a percentage of the mean for a 15 months period for three standards (58.8 - 117.6 - $176.5 \mu \mathrm{mol} / \mathrm{L})$ were respectively $4.06,2.56$, and $2.96 \%(n=147)$. Intraassay variations, given as coefficients of variation, expressed as a percentage of the mean for three standard solutions $(58.8$ - 117.6 - $176.5 \mu \mathrm{mol} / \mathrm{L})$ were respectively $3.08,1.78$, and $0.8 \%(\mathrm{n}=20)$.

Experiment 1: Food versus whole blood.

In fasting animals $(n=10)$, portal ammonia levels $(177 \pm 15 \mu \mathrm{mol} / \mathrm{L})$ always exceeded the arterial levels $(47 \pm 5 \mu \mathrm{mol} / \mathrm{L})(\mathrm{p}<0.001)$. After the standard pigmeal $(750 \mathrm{~g})$, this difference progressively increased and reached a maximum two to three hours after ingestion. Thereafter it progressively decreased. At $t=6(202 \pm 26 \mu \mathrm{mol} / \mathrm{L})$ it was only slightly higher than the basal level. After the isonitrogenous blood meal porta-arterial ammonia difference exceeded that following the standard meal. During the six hour study period porta-arterial difference showed no tendency to decline $(t=6: 396 \pm 67 \mu \mathrm{mol} / \mathrm{L})$ while ammonia levels were significantly higher than after the standard meal from $t=1$ hour onwards. Small bowel ammonia production equalled $44.5 \pm 7.5 \mathrm{mmol}$ after the standard meal and $98 \pm 37.2 \mathrm{mmol}$ after the blood meal over the six hour study period. During this period large bowel ammonia production was $30.7 \pm 7.4$ mmol after the standard meal and $27.1 \pm 6.8 \mathrm{mmol}$ following the blood meal. Experiment 2: Food/plasma/erythrocytes/whole blood. 
In the second series of experiments intestinal production of ammonia was $72.9 \pm 14.6$ mmol for the six hours following the standard meal. After an isonitrogenous but hypocaloric amount of plasma $74.9 \pm 15.7$ mmols were produced, whereas after the erythrocytes and whole blood meal a significantly higher production of $141 \pm 26.8$ and $104 \pm 16.7 \mathrm{mmol}$ was found respectively.

\subsubsection{Urea levels (figure $I b$ ).}

Experiment 1: In the fasting state arterial urea levels $(2320 \pm 353 \mu \mathrm{mol} / \mathrm{L})$ always exceeded portal values $(2210 \pm 291 \mu \mathrm{mol} / \mathrm{L})$. Only a slight increase in systemic levels was observed after the standard meal $(t=6: 3565 \pm 330 \mu \mathrm{mol} / \mathrm{L})$, while porta-arterial differences were zero or stayed negative. For the 6 hours study period no maximum was reached. After the isonitrogenous blood meal a fast rise in systemic urea levels was noted. From $t=3$ onwards urea levels were significantly higher than after the standard meal $(6225 \pm 558 \mu \mathrm{mol} / \mathrm{L})$.

Experiment 2: In the second series of experiments in the fasting state arterial levels equalled portal levels. Ingestion of plasma had no effect on systemic urea levels as compared to controls. Erythrocytes and whole blood meals resulted in higher urea levels, compared with food or plasma, comparable with those in the first series of experiments.

\subsubsection{Amino acid levels.}

\section{Alpha-amino-nitrogen (figure Ic, table 2):}

Alpha-amino-nitrogen was derived by adding all individual amino acids.

Experiment 1: In all experiments $(n=20)$, the blood levels of the sum of amino acids measured after 16 hours of fasting were of the same order of magnitude in the portal $(2771 \pm 192 \mu \mathrm{mol} / \mathrm{L})$ and arterial blood $(2796 \pm 158 \mu \mathrm{mol} / \mathrm{L})$.

After the standard meal amino acid levels rapidly increased reaching maximum values which were definitely higher in the portal than in the arterial blood $(4236 \pm 265 \mu \mathrm{mol} / \mathrm{L}$ versus $3692 \pm 196 \mu \mathrm{mol} / \mathrm{L} ; \mathrm{p}<0.01)$. This was even more pronounced in the bloodmeal experiments $(8413 \pm 504 \mu \mathrm{mol} / \mathrm{L}$ versus $7360 \pm 410$ $\mu \mathrm{mol} / \mathrm{L})$. The absolute portal values were significantly higher $(\mathrm{p}<0.01)$ after ingestion of the $400 \mathrm{ml}$ whole blood meal than after the $750 \mathrm{~g}$ standard meal. For the standard meal a plateau was reached between one and three hours, while for the bloodmeal a sharp maximum was observed after two hours.

Experiment 2: After the ingestion of $210 \mathrm{~g}$ standard pig food analogous results as to the first series of experiments were observed. A small increase was observed in systemic $\alpha$-amino-nitrogen levels from $2540 \mu \mathrm{mol} / \mathrm{L}$ on $\mathrm{t}=0$ to 3601 $\mu \mathrm{mol} / \mathrm{L}$ on $\mathrm{t}=6$. After the plasma meals systemic levels rose from $2541 \mu \mathrm{mol} / \mathrm{L}$ on $t=0$ to $4576 \mu \mathrm{mol} / \mathrm{L}$ on $t=1$. The erythrocytes and whole blood meals increased to $5847 \mu \mathrm{mol} / \mathrm{L}$ and $7060 \mu \mathrm{mol} / \mathrm{L}$ respectively, which was significantly higher than following the standard meal. 
Experiment 1: Fasting systemic glutamine levels $(407 \pm 39 \mu \mathrm{mol} / \mathrm{L})$ were always higher than portal values $(342 \pm 41 \mu \mathrm{mol} / \mathrm{L})$. This net intestinal glutamine utilization was also observed after a standard meal or after a blood meal. While systemic levels increased, net porta-arterial differences became less negative during the first three hours, reaching basal values after the standard meal on $t=6$. No significant difference was observed in glutamine utilization between standard meal and blood meal. Small bowel glutamine utilization was $7.4 \pm 3.0 \mathrm{mmol}$ after the standard meal and $9.4 \pm 2.1$ mmol during the six hours after the whole blood meal. In this period the large bowel utilized $1.8 \pm 0.2$ and $0.7 \pm 0.3 \mathrm{mmol}$ respectively.

Experiment 2: Total intestinal glutamine utilization amounted to $16.2 \pm 5.3 \mathrm{mmol}$ during the six hour period after the standard meal, $18.4 \pm 7.4 \mathrm{mmol}$ after the plasma meal, $15.4 \pm 4.6 \mathrm{mmol}$ following the erythrocytes meal, and $15.6 \pm 3.5$ mmol after the whole blood meal.

\section{Alanine (figure $2 b$, table 2):}

Experiment 1: In the fasting state arterial levels of alanine were equal to portal levels $(200 \pm 29 \mu \mathrm{mol} / \mathrm{L}$ versus $229 \pm 22 \mu \mathrm{mol} / \mathrm{L})$. After the standard meal a significant porta-arterial difference of alanine was observed reaching its maximum on $t=3(210 \mu \mathrm{mol} / \mathrm{L})$ declining by $t=6$ to the level of $t=1(139 \mu \mathrm{mol} / \mathrm{L})$. After the blood meal systemic alanine levels increased $(534 \pm 57 \mu \mathrm{mol} / \mathrm{L})$. Portaarterial differences significantly increased, but no statistical difference was observed between standard meal and blood regimen (max: $210 \pm 48 \mu \mathrm{mol} / \mathrm{L}$ versus $244 \pm 48 \mu \mathrm{mol} / \mathrm{L})$.

Experiment 2: In the second series of experiments similar results were seen. Total intestinal absorption was $42.7 \pm 7.7 \mathrm{mmol}$ during the 6 hours after the standard meal and $20.6 \pm 2.7 \mathrm{mmol}$ following the plasma meal (table 2). After the erythrocyte and whole blood meals these values were: $47.8 \pm 7.2$ and $34.8 \pm 4.9 \mathrm{mmol}$ respectively.

\section{Isoleucine (figure $3 a$, table 2):}

Experiment 1: In the fasting state arterial levels of isoleucine equalled portal levels $(132 \pm 7 \mu \mathrm{mol} / \mathrm{L}$ versus $128 \pm 9 \mu \mathrm{mol} / \mathrm{L}$ ). After the standard meal a significant porta-arterial difference of isoleucine was observed reaching its maximum at $t=3(46.4 \mu \mathrm{mol} / \mathrm{L})$ declining by $t=6$ to the level of $t=1(17.4 \mu \mathrm{mol} / \mathrm{L})$. After the blood meal systemic isoleucine levels decreased $(31 \pm 5 \mu \mathrm{mol} / \mathrm{L})$ to $25 \%$ of basal levels, while porta-arterial differences were significantly lower than after the standard meal (max: $23.9 \mu \mathrm{mol} / \mathrm{L}$ ).

Experiment 2: In the second series of experiments similar results were seen following the standard and plasma meals. Total intestinal absorption was $8.2 \pm 1.1 \mathrm{mmol}$ for 6 hours after the standard meal and $4.2 \pm 1.0 \mathrm{mmol}$ following the plasma meal (table 2). These values were significantly lower following the erythrocytes $(2.6 \pm 0.8 \mathrm{mmol})$ and whole blood meals $(3.4 \pm 0.9 \mathrm{mmol})$. 
Experiment 1: In the fasting state arterial levells of leucine were equal to portal levels $(167 \pm 9 \mu \mathrm{mol} / \mathrm{L}$ versus $144 \pm 7 \mu \mathrm{mol} / \mathrm{L})$. After the standard meal a significant porta-arterial difference of leucine was observed reaching its maximum at $\mathrm{t}=3(77 \pm 16 \mu \mathrm{mol} / \mathrm{L})$ declining by $\mathrm{t}=6$ to the level of $\mathrm{t}=1(39 \pm 11 \mu \mathrm{mol} / \mathrm{L})$. After the blood meal systemic leucine levels increased $(925 \mu \mathrm{mol} / \mathrm{L})$. Uptake was significantly increased $(29.8 \pm 9.8 \mathrm{mmol} / 6 \mathrm{br})$ compared to the standard meal $(15.2 \pm 3.0 \mathrm{mmol} / 6 \mathrm{hr})$.

Experiment 2: In the second series of experiments similar results were seen after the standard and plasma meals. Total intestinal absorption was $12.8 \pm 3.1$ mmol for the 6 hours following the standard meal and $8.6 \pm 1.6 \mathrm{mmol}$ following the plasma meal (table 2). After the erythrocyte and whole blood meals these values were significantly increased: $33.8 \pm 8.4$ and $48.0 \pm 12.5 \mathrm{mmol}$ respectively.

\section{Valine (figure $3 c$, table 2):}

Experiment 1: In the fasting state arterial levels of valine were equal to portal levels $(259 \pm 16 \mu \mathrm{mol} / \mathrm{L}$ versus $255 \pm 19 \mu \mathrm{mol} / \mathrm{L})$. After the standard meal a significant porta-arterial difference of valine was observed reaching its maximum at $t=3(55 \pm 14 \mu \mathrm{mol} / \mathrm{L})$ declining by $t=6$ to the level of $t=1(27 \pm 5 \mu \mathrm{mol} / \mathrm{L})$. After the blood meal systemic valine levels increased $(1138 \pm 128 \mu \mathrm{mol} / \mathrm{L})$. Uptake was significantly increased $(24.7 \pm 6.1 \mathrm{mmol} / 6 \mathrm{hr})$ compared to the standard meal $(11.4 \pm 1.9 \mathrm{mmol} / 6 \mathrm{hr})$.

Experiment 2: In the second series of experiments similar results were seen after the standard and plasma meals. Total intestinal absorption was $12.9 \pm 2.7$ mmol for the 6 hours after the standard meal and $7.7 \pm 0.9 \mathrm{mmol}$ following the plasma meal (table 2). Following the erythrocyte and whole blood meals these values were significantly increased: $28.8 \pm 5.7$ and $23.3 \pm 3.5 \mathrm{mmol}$ respectively.

\subsubsection{Discussion.}

The observation that blood gives a higher increase to ammonia liberation than an isonitrogenous standard pigmeal is in accordance with earlier reports from Bessman $(1958,1963)$. Breakdown of protein results in formation of ammonia, urea, oligopeptides, amino acids, and other nitrogenous substances each along specific metabolic pathways. It is not clear which of these is the most important precipitant in protein induced PSE. A hierarchy in the degree of toxicity and the ammonia liberating potential has been described for different types of protein (Greenberger 1977; Uribe 1982, 1985; Keshavarzian 1984; Young 1957; Bessman 1958, 1963). Gram for gram blood appears to be more toxic than meat, which in turn is more toxic than dairy or vegetable protein (Conn 1979). The importance of these observations resides in the fact that bleeding from the gastrointestinal tract often heralds PSE (Müting 1983). Bessman and Mirick (1958) and Young (1957) reported a higher increase in blood ammonia after the oral intake of blood than after an equal amount of milk protein. Fenton et 
al (1966) suggested that dairy protein is less toxic than meat, and Greenberger, Carley and Schenker (1977), proposed the same for vegetable protein. Smith et al (1964) found a greater toxicity after oral ingestion of mixtures of hydrolyzed casein than after pure casein, but were unable to confirm the greater toxicity of meat than dairy protein. Greenberger (1977) further proposed an improved protein tolerance during short term vegetable protein studies, based on a more positive nitrogen balance because of decreased urinary urea excretion. A better vegetable protein tolerance was also observed by Morgan (1981), Uribe (1982), Jeppson (1984) and Jonung (1987). De Bruijn (1983) described the same trend in a long-term study with stable postshunt cirrhotic patients. The difference in toxicity of the various proteins has been ascribed to many factors. Differences in composition of protein may cause differences in rate of digestion and mechanism of absorption (Conn 1979). As the blood meal resulted in melena after about 6 hours, while its ammonia liberating effect was greater than of a standard meal, it is difficult to conceive that this is due to more rapid absorption or increased contact time between blood and the bowel. Differences in amino acid composition may have biochemical and physiological consequences (Conn 1979). Rudman (1973) described differences in ammonia release of various amino acids; a high potency group of directly deaminating or deamidating amino acids (glycine, serine, threonine, glutamine, histidine, lysine, and asparagine) was compared with less potent amino acids (leucine, alanine, valine, phenylalanine, isoleucine, tyrosine, proline, and arginine, aspartic acid, glutamic acid, tryptophan, and the non-amino acid urea). These amino acids yield ammonia indirectly i.e. after transamination. "Synergism" might even complicate this picture as has been described for arginine, decreasing the ammoniagenic effect of glycine or mixtures of amino acids (Greenstein 1956). Pigfood contains much more serine, glycine, and asparagine (table 1), while the differences in other amino acids are less obvious. Therefore differences in constituting ammonia liberating amino acids cannot explain the higher ammonia liberation after blood in our study. A physiological consequence of the amino acid composition has been proposed by Bessman (In: Conn 1979) He postulated increased shunting of blood, permitting potential toxic nitrogenous products of digestion to escape liver metabolism, after the ingestion of proteins rich in histidine, known to have a portal vasoconstrictive effect. Although the histidine content of blood is indeed higher, the pigs used have normal liver function, and therefore this explanation does not apply in our study. Rudman (1973) stated that different foods might differ in free ammonia content. The ammonia content of blood and pigmeal did not differ to the extent that it might explain the higher ammonia and urea levels observed. Uribe (1985) points out that dietary fiber decreases the digestion of vegetable protein which results in a more gradual supply of amino acids. Furthermore inclusion of fat and carbohydrate in the meal decreases transit time, prolonging the duration of absorption. These mechanisms might explain the difference in absorption between pigfood and whole blood in the first experiment. However in the second experiment this can not explain the differences between plasma, whole blood and erythrocytes, which all lack fiber, fat and carbohydrates. 
While reviewing the role of protein in the pathogenesis of PSE, it becomes clear that much emphasis has been put on bacterial metabolism. Intraluminal bacterial ammonia formation does not explain why germfree-animals can develop hyperammonemia as has been emphasized on the basis of studies done by Nance (1974) and Sugarbaker (1987). Nance (1974) reported PSE in germfree Eck-fistula dogs with hyperammonemia, and showed that a blood meal induced the same increase in ammonia concentration. Sugarbaker (1987) demonstrated, in experiments performed in dogs, that decontamination of the gut did not result in a difference in small bowel ammonia production, indicating non-bacterial mechanisms. During the last few years many investigations reported a role for glutamine in bacterial independent ammonia production. Windmueller and Spaeth (1975) have shown the importance of intestinal metabolism of glutamine, in yielding ammonia, citrulline, alanine, and glutamate derived either from the lumen or from the blood. These studies were carried out in isolated and in vivo vascularly perfused preparations of rat intestine. These studies improve the understanding of the studies of Weber and Veach (1979). They stated that in dogs about $50 \%$ of total intestinal ammonia production is derived from small bowel glutamine utilization, while about $25 \%$ is derived from large bowel glutamine metabolism and the rest from bacterial metabolism. Glutamine uptake was not increased after ingestion of blood constituents compared to pigfood, so that glutamine degradation was not responsible for increased ammonia liberation after blood intake. It is generally accepted that one way of producing intestinal ammonia is by enzymatic breakdown of protein metabolites and urea (Salter 1973), and that bacteria mediate this process predominantly in the distal gut, specifically distal ileum, cecum, and proximal colon. Selective sampling of venous blood from several parts of the digestive tract in this study reveals that specifically the small bowel produces ammonia and that the enormous increase of ammonia production after ingestion of whole blood or erythrocytes is mainly the result of increased ammonia production in the small bowel (table 2), as has been proposed recently (Sugarbaker 1987). It should be acknowledged that the measurement and calculation of flow to specific parts of the splanchnic region suffers from large fluctuations and is therefore liable to over- or underestimation. However our results are in agreement with data in the literature (Tranquilli 1982). This together with the observation that portaarterial differences for ammonia across the small bowel are substantially higher than across the large bowel leads us to conclude that the small bowel produces more ammonia than the large bowel. It is unlikely that bacterial urease mediates the increase in ammonia production after ingestion of blood or erythrocytes. Despite a small and consistent uptake of urea across the gut in the fasted state and because the blood products administered contained negligible amounts of urea the uptake of urea did not increase after ingestion of blood or blood products. The high systemic urea levels occurring after ingestion of blood or erythrocytes are striking. The experimental setup excludes the possibility that this is due to catabolism resulting from shock. This suggests that although shock may in clinical practice be a contributing factor it is not a prerequisite for increased urea- and ammonia production in patients that suffer from gastro-intestinal bleeding. Whole blood and specifically erythrocytes stimu- 
late catabolism as evidenced by increased urea levels which is distinct from what occurs after ingestion of isocaloric isonitrogenous plasma, or hypercaloric and isonitrogenous pigfood. This proves that in the experimental setting employed the caloric intake did not influence urea production but rather the type of protein ingested. Another striking finding in this study was the extreme hyperaminoacidemia and simultaneously the extremely low isoleucine levels found after ingestion of whole blood or erythrocytes. This prompted us to investigate the amino acid content of hemoglobin, constituting two thirds of blood protein, and of albumin, and it appeared both from our analysis (table 1) and from data in the literature (Antonini 1971; Dayhof 1972) that adult hemoglobin does not contain isoleucine whereas the albumin molecule contains only one molecule of isoleucine. It is well known since decades that dietary protein or amino acid mixtures lacking or deficient in one or more essential amino acids inhibit growth in the chronic experiment (Rose 1955). The results of this study suggest that administration of protein lacking one essential amino acid acutely elicits a catabolic stimulus. This must be the result of diminished protein synthesis, increased degradation, or both. After an ordinary meal net protein synthesis occurs in muscle but also in the gut whereas in the postabsorptive state net protein degradation ensues, after $24 \mathrm{hr}$ resulting in a zero balance. The prolonged hyperaminoacidemia observed after whole blood or erythrocytes indeed suggests that amino acids absorbed cannot be sufficiently utilized for protein synthesis due to lack of isoleucine. As a result they accumulate in the systemic circulation, and by virtue of their high levels stimulate ureagenesis (Eggum 1970). Even after 24 hours urea levels did not regain basal levels. The decrease in protein synthesis can only result in increased urea production when protein degradation continues. This is even more likely because after 24 hours arterial isoleucine levels have normalized which can only occur as a result of replenishment of the plasma pool due to protein degradation (figure 3a). The two other branched chain amino acids leucine and valine, sharing the same transport mechanisms, appear to a far greater extent in the portal circulation, causing a significant increase in systemic levels. Administration of protein of low biological value like hemoglobin may depress net protein synthesis of the bowel wall during feeding, which may explain the net increase in apparent absorption of $\alpha$-amino-nitrogen during digestion of whole blood and erythrocytes.

In conclusion we hypothesize that the hierarchy in toxicity of different proteins may be the consequence of their biological value. The absence of isoleucine in hemoglobin may lead to depressed protein synthesis (Wunner 1966), which results in a diminished utilization of all other amino acids required for protein synthesis. As a result net protein degradation and increased ureagenesis occurs. Increased arterial free $\alpha$-amino-nitrogen may lead to increased production of ammonia in the gut. From these experiments it cannot be inferred which amino acids are the main precursors for ammoniagenesis. 


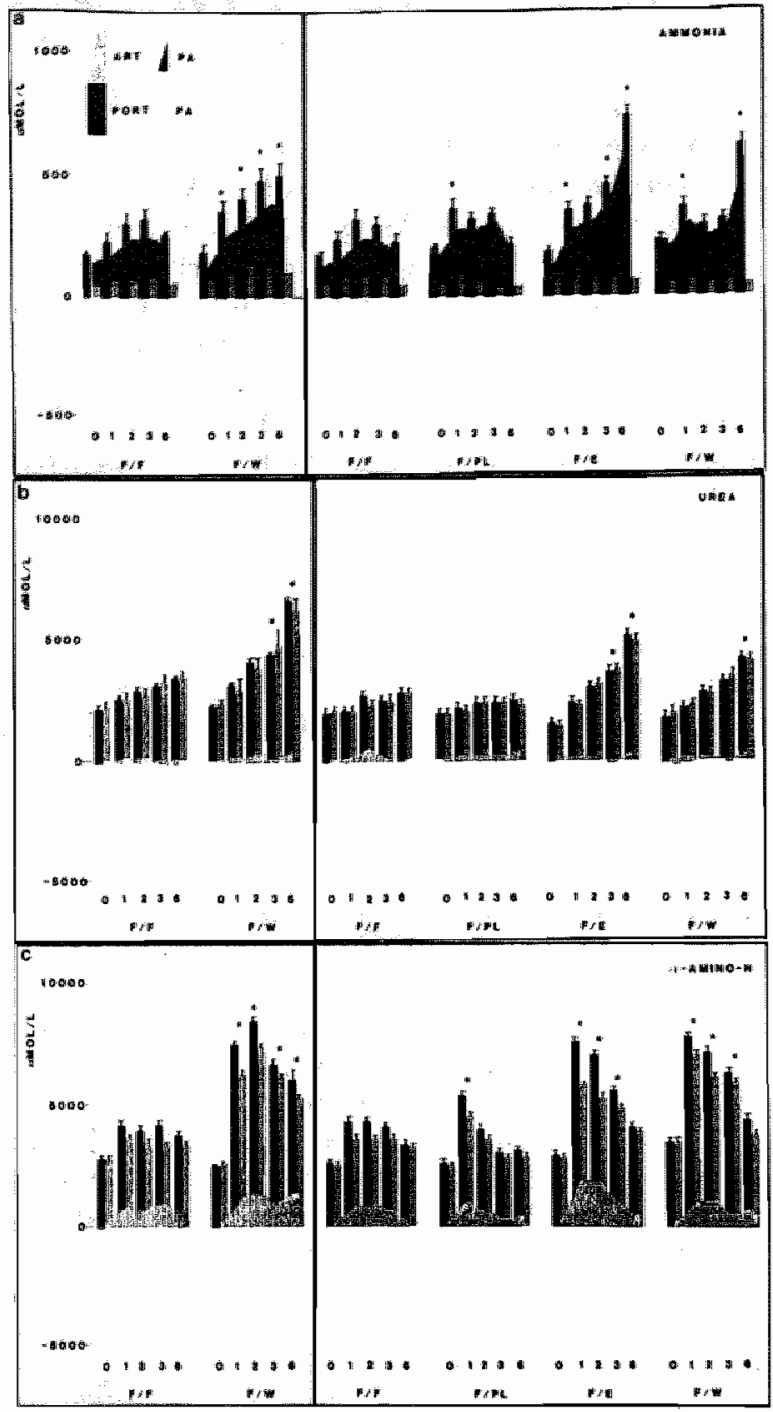

Pigure 1 Plasma ammonia (1a), urea (1b), and a-amino-nitrogen (1c) concentrations ( $\mu \mathrm{mol} / \mathrm{L}_{\text {; }}$ mean \pm sem) with time fiter a standard meal (F/F, $750 \mathrm{~g}, 12 \%$ protein), after a blood meal $(\mathrm{F} / \mathrm{W} ; 400 \mathrm{ml} ; \mathrm{n}=10$ pigs), after a standard meal $(\mathrm{F} / \mathrm{F} ; 210 \mathrm{~g})$, after plasma $(\mathrm{P} / \mathrm{PL}$; $400 \mathrm{ml})$, erythrocytes $(\mathrm{F} / \mathrm{E} ; 125 \mathrm{ml})$, and whole blood $(\mathrm{F} / \mathrm{W} ; 192 \mathrm{ml})(\mathrm{n}=3)$. ART $=$ arterial, $\mathrm{PORT}=$ portal, $\mathrm{PA}=$ portal minus arterial. $=\mathrm{P}<0.05$ as compared to controls. 


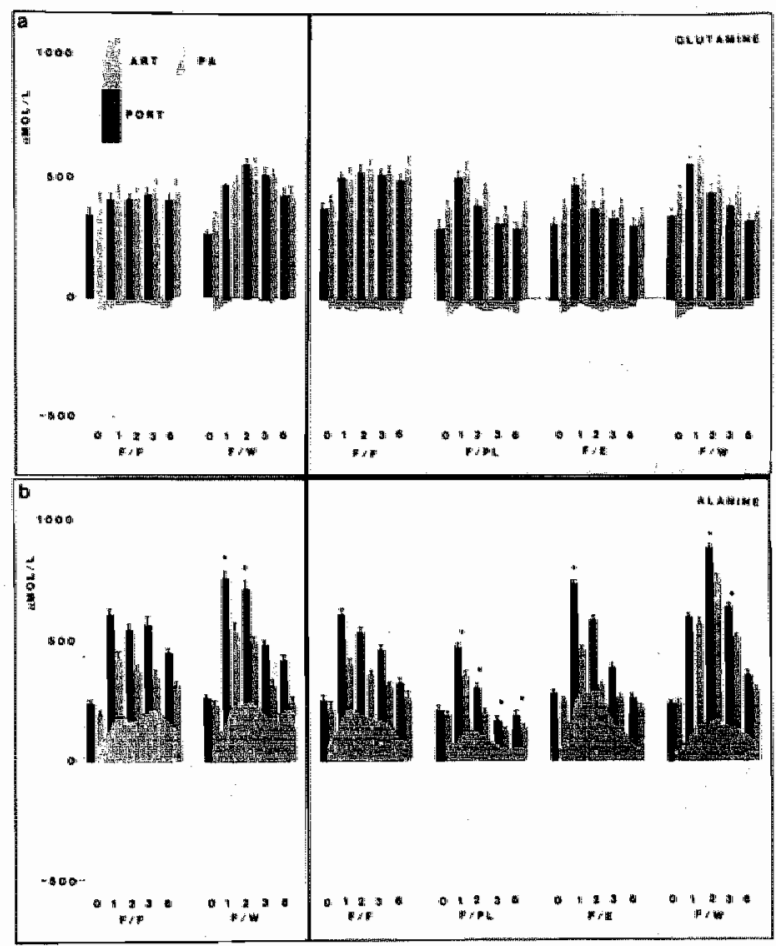

Figure 2 Plasma glutamine (2a) and alanine (2b) concentrations ( $\mu$ mol/L; mean \pm sem) with time after a standard meal (F/P; 750 g $12 \%$ protein), after a blood meal (F/W; 400ml) $(\mathrm{n}=10$ pigs), after a standard meal $(\mathrm{F} / \mathrm{F} ; 210 \mathrm{~g})$, after plasma $(\mathrm{P} / \mathrm{PL} ; 400 \mathrm{ml})$, erythrocytes (P/E; $125 \mathrm{ml})$, and whole blood ( $\left.F / \mathrm{W}_{;}, 192 \mathrm{ml}\right)(\mathrm{n}=3)$. ART $=$ arterial, PORT $=$ portal, $P A=$ portal minus arterial. $=p<0.05$ as compared to controls. 


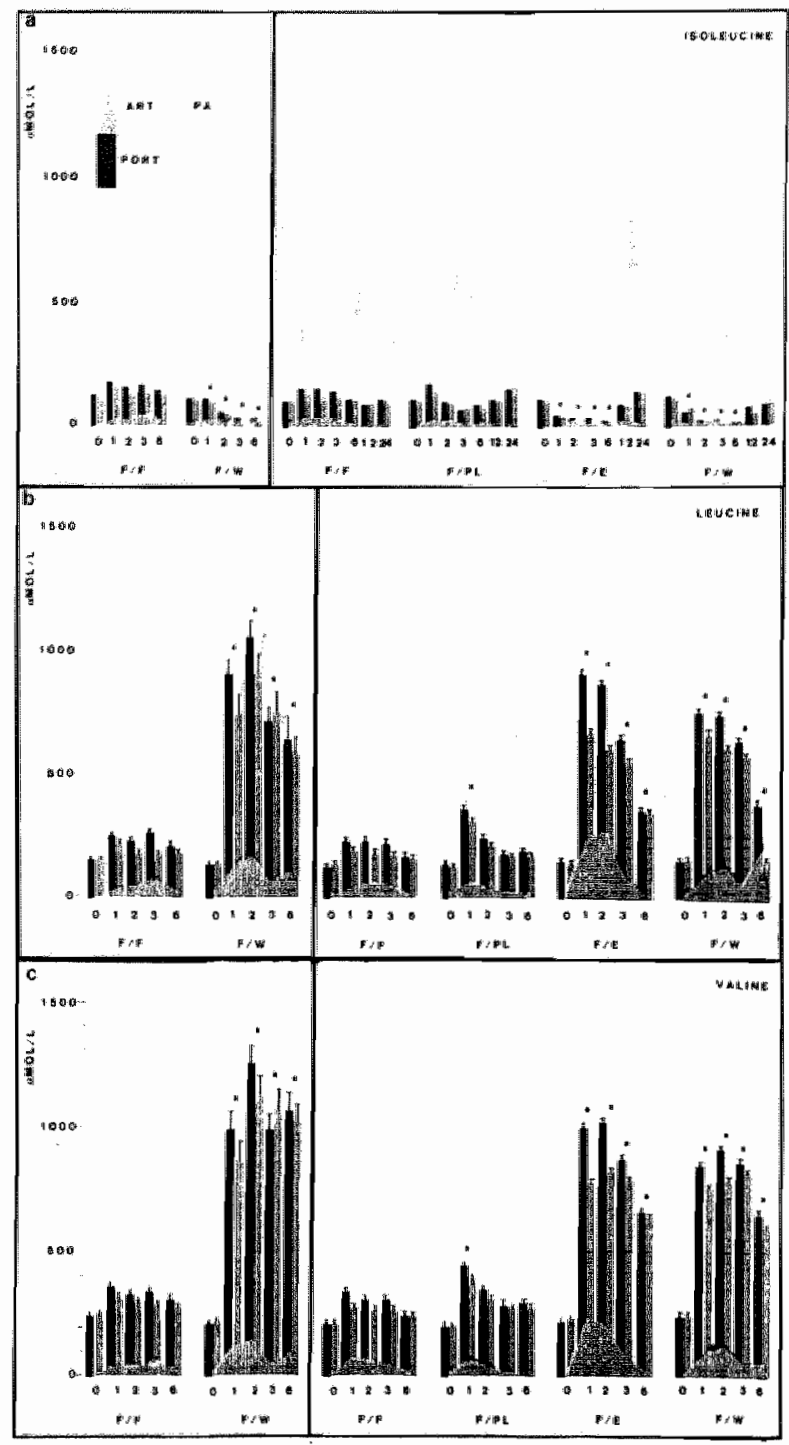

Figure 3 Plasma isoleucine ( $3 a)$, leucine (3b), and valine (3c) concentrations ( $\mu$ mol/L; mean \pm sem) with time after a standard meal ( $\mathrm{F} / \mathrm{F} ; 750 \mathrm{~g}, 12 \%$ protein), after a blood meal (F/W; $400 \mathrm{ml} ; \mathrm{n}=10$ pigs), after a standand meal ( $\mathrm{F} / \mathrm{F} ; 210 \mathrm{~g}$ ), after plasma (F/PL; $400 \mathrm{mll}$ ), erythrocytes $\left(\mathrm{F} / \mathrm{E}^{\prime} ; 25 \mathrm{ml}\right)$, and whole blood $(\mathrm{F} / \mathrm{W} ; 192 \mathrm{ml})(\mathrm{n}=3)$. ART $=$ arterial, $\mathrm{PORT}=$ portal, $\mathrm{PA}=$ portal minus arterial. $\mathrm{p}<0.05$ as compared to controls. 


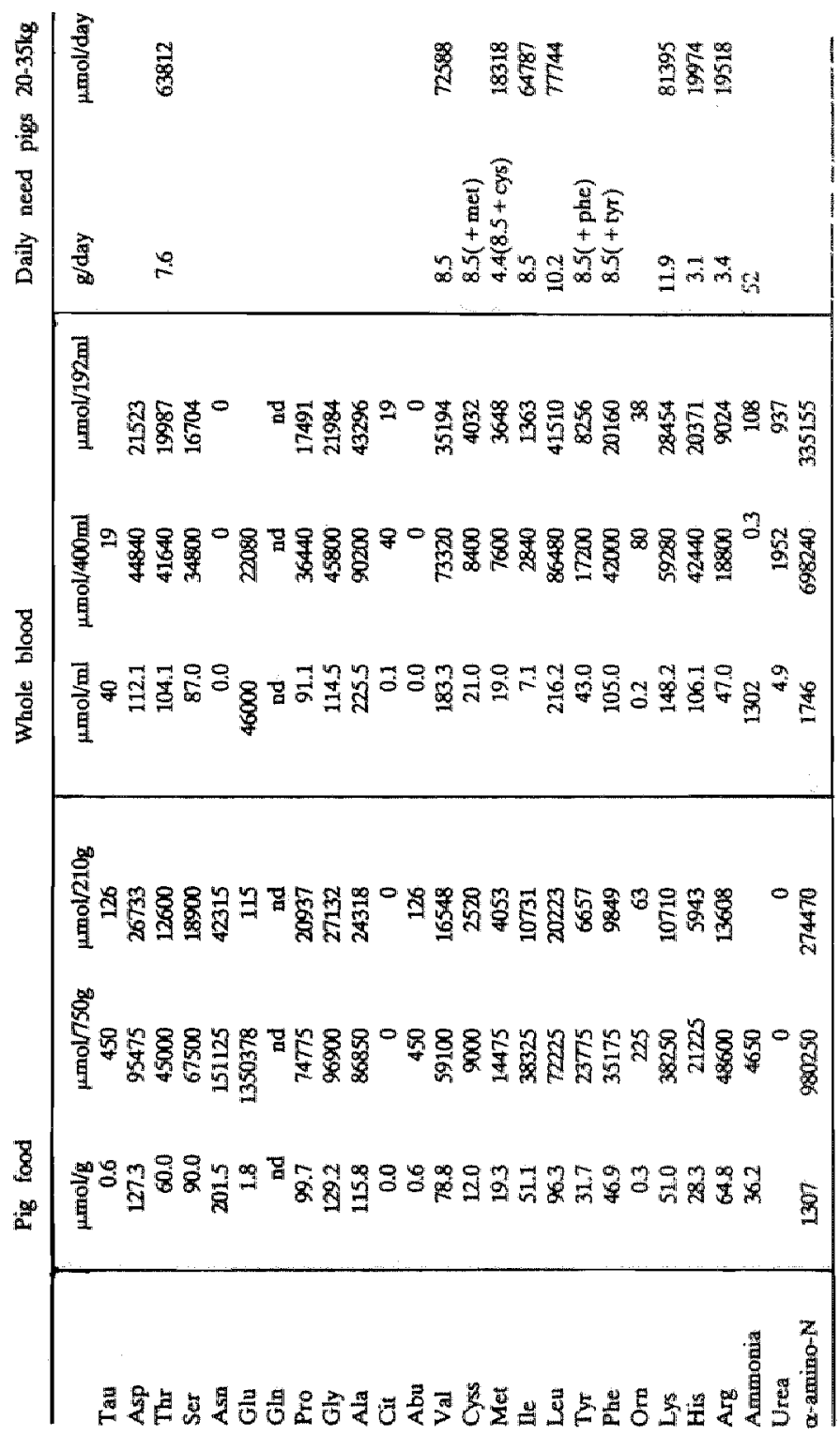

Table 1: Amino acid content of pig food and bovine whole blood compared to daily need. 


\begin{tabular}{|c|c|c|c|c|c|c|}
\hline & \multicolumn{6}{|c|}{ Expetriment 1} \\
\hline & $\begin{array}{l}\text { f/f } \\
\text { portal }\end{array}$ & $\begin{array}{l}\mathbb{f}[\mathrm{f} \\
\operatorname{smal}\end{array}$ & $\begin{array}{l}\text { lof } \\
\text { large }\end{array}$ & $\begin{array}{l}\text { fow } \\
\text { portal }\end{array}$ & $\begin{array}{l}\mathbb{H} / \mathrm{w} \\
\text { small }\end{array}$ & $\begin{array}{l}\text { fhw } \\
\text { large: }\end{array}$ \\
\hline ammomia & $66.3 \pm 9.2$ & $445=7.5$ & $30.7 \pm 7.4$ & $101.7 \pm 19.3$ & $98.0 \pm 37.2$ & $27.1 \pm 6.8$ \\
\hline$\alpha-\operatorname{amino} N$ & $174.2 \pm 36.6$ & $187.6 \pm 263$ & $-57.4=10.3$ & $294.9+47.1$ & $1510 \pm 528$ & $-10.1=3.0$ \\
\hline isolevcine & $8.6 \pm 1.7$ & $1.2 \pm 02$ & $-0.4 \pm 0.1$ & $5.4 \pm 1.3$ & $3.3 \pm 1.0$ & $-0.7 \pm 0.1$ \\
\hline leucine & $15.2 \pm 3.0$ & $16.4 \pm \quad 38$ & $-0.7 \pm 0.2$ & $29.8 \pm 9.8$ & $20.0 \pm 5.0$ & $-1.5 \pm 0.3$ \\
\hline valine & $11.4 \pm 1.9$ & $130 \div 21$ & $-0.6 \pm 0.1$ & $24.7 \pm 6.1$ & $19.0 \pm 21$ & $-0.8 \div 0.1$ \\
\hline glutamine & $-136 \pm 4.5$ & $-7.4 \pm 3.0$ & $-1.8 \pm 0.2$ & $-3.1 \pm 0.7$ & $-9.4 \pm 2.1$ & $-0.7 \pm 0.3$ \\
\hline \multirow[t]{3}{*}{ alanine } & $52.4 \pm 7.3$ & $440 \pm 7.5$ & $0.3 \pm 0.1$ & $59.8 \pm 7.2$ & $278 \pm 4.2$ & $-0.3 \pm 0.1$ \\
\hline & \multicolumn{2}{|c|}{ Experiment 2} & & & & \\
\hline & $\begin{array}{l}\text { f/f } \\
\text { portal }\end{array}$ & $\begin{array}{l}\text { f/p } \\
\text { portal }\end{array}$ & $\begin{array}{l}\text { fle } \\
\text { portal }\end{array}$ & $\begin{array}{l}\text { f/w } \\
\text { portal }\end{array}$ & & \\
\hline ammionia & $72.9=14.6$ & $74.9 \pm 157$ & $1414 \pm 268$ & $104.4 \pm 16.7$ & & \\
\hline$\alpha-\operatorname{amino-M}$ & $173.1 \pm 36.3$ & $107.7 \pm 32.3$ & $253,0 \pm 75.9$ & $210.6 \pm 52.7$ & & \\
\hline iscleucine & $8.2 \pm 1.1$ & $4.2 \pm 1.0$ & $26 \pm 0.8$ & $3.4 \pm 0.9$ & & \\
\hline leucine & $12.8 \pm 3.1$ & $8.6 \pm 1.6$ & $33.8 \pm 8.4$ & $48.0 \pm 12.5$ & & \\
\hline valine & $12.9 \pm 2.7$ & $7.7 \pm 0.9$ & $28.8 \pm 5.7$ & $23.3 \pm 3.5$ & & \\
\hline glutamine & $-16.2 \pm 5.3$ & $-18.4 \pm 7.4$ & $-15.4 \pm \quad 4.6$ & $-15.6 * 3.5$ & & \\
\hline alanine & $42.7 \pm 7.7$ & $20.6 \pm 2.7$ & $47.8 \pm 7.2$ & $34.8 \pm 4.9$ & & \\
\hline
\end{tabular}

Table 2: Production $(+)$ or utilization $(-)($ mean $\pm \operatorname{sem})$ of ammonia and amino acids in small bowel, large bowel and total gut after $750 \mathrm{~g}$ pregnant sow feed $(\mathbb{E} / \mathrm{f}), 400 \mathrm{ml}$ bovine whole blood (f/w) (Experiment 1), 210 g pregnant sow feed (f/f), 400 mll bovine plasma (f/p), $125 \mathrm{ml}$ bovine erythrocytes (f/e), and $192 \mathrm{ml}$ bovine whole blood (t/w) (Experiment 2) in mmol/6 hours.

* p $<0.05$ as compared to controls. 


\section{CHAPTER 3.2.}

EFFECTS OF ISOLEUCINE ADMINISTRATION ON AMINO ACID METABOLISM AFTER INTESTINAL BLEEDING: A STUDY IN PIGS.

\subsubsection{Abstract.}

A hierarchy in the degree of toxicity of different types of protein has been reported in liver disease. Recently we hypothesized that due to a complete lack of isoleucine in hemoglobin ingestion of blood presents the host with protein of low biological value, leading to decreased protein synthesis and to net protein degradation, leading to increased ammonia- and ureagenesis. The aim of this study was to establish the effect of ingestion of erythrocytes with and without isoleucine on intestinal ammonia and amino acid metabolism. Blood was sampled from catheterized piglets $(20 \pm 0.8 \mathrm{~kg}$; mean $\pm \mathrm{sem} ; \mathrm{n}=10)$ to determine ammonia, urea, lactate, and amino acid levels before, one, two, three, four, six, and eight hours after the ingestion of an erythrocyte meal ( $400 \mathrm{ml}$, $80.6 \mathrm{~g}$ protein, < $50 \mathrm{Kcal})$. After a week this procedure was repeated following ingestion of an isonitrogenous amount of isoleucine enriched erythrocytes $(375 \mathrm{ml}, 10 \mathrm{~g}$ isolleucine, $80.6 \mathrm{~g}$ protein, < $50 \mathrm{Kcal})$. Electromagnetically measured portal blood flow was not influenced by the type of blood ingested. The enrichment of erythrocytes with an excess of isoleucine diminishes ammoniagenesis and ureagenesis, but not significantly. Significantly less lactate was metabolized following the isoleucine enriched erythrocyte meal. Less alanine was consumed, indicating decreased protein degradation. These data further support the hypothesis that the increased toxicity of blood protein is secondary to its protein structure, in particular the absence of isoleucine in the hemoglobin molecule. As we have administered excess of isoleucine, these experiments need to be repeated with less isoleucine.

\subsubsection{Introduction.}

Gastro-intestinal bleeding is known to induce profound malaise and a negative nitrogen balance, and especially in patients with liver failure, it gives rise to high plasma ammonia levels and is thought to precipitate hepatic encephalopathy (McDermott 1954; Mutchnick 1974; Gaustad 1949; Summerskill 1957; Welch 1956; Faloon 1970). A hierarchy in the degree of toxicity of different types of orally ingested protein has been reported in patients at risk for hepatic encephalopathy. Gram for gram, blood appears to be more toxic than meat, which in turn appears to be more toxic than dairy or vegetable protein (Greenberger 1977; De Bruijn 1983; Uribe 1982, 1985; Keshavarzian 1984; Young 1957; Bessman 1958, 1963). Many explanations have been offered for the differences in coma-inducing potential of these protein sources. These include different sites of degradation and different content of free ammonia and amino acids (Conn 1979; Rudman 1973; Greenstein 1956). Recently we studied the fate of amino 
acids and ammonia after intestinal blood intake in a pig model (Van Berlo 1988). As a result of these studies we hypothesized that the hierarchy in toxicity of different proteins may just be the consequence of their biological value. The absence of isolleucine in hemoglobin (Antonini 1971; Dayhof 1972) may lead to depressed protein synthesis, which results in a diminished utilization of all other amino acids required for protein synthesis. As a result net protein degradation and increased ureagenesis occurs. Increased arterial free $\alpha$-amino-nitrogen may lead to increased production of ammonia in the gut. To investigate this hypothesis and to determine the role of isoleucine we studied the fates of erythrocytes and isoleucine enriched erythrocytes in pigs.

\subsubsection{Materials and methods.}

\subsubsection{Animals.}

Female crossbred (Yorkshire $x$ Dutch Landrace) piglets $(20 \pm 0.8 \mathrm{~kg}$ (mean $\pm \mathrm{sem} ; \mathrm{n}=10$ ) were used and individually housed in galvanized bar runs (203 meters) equipped with an automatic watering device. Animals were placed in the pen and acclimatized to their new surroundings for at least three days before surgery. In this period they became accustomed to the investigator and to a small movable cage $(0.9 \times 0.5 \times 0.3 \mathrm{~m})$ used during blood sampling. Throughout the experimental period animals were treated according to the guidelines of the European convention for the protection of vertebrate animals used for experimental and other scientific purposes.

\subsubsection{Surgical procedures.}

Animals were fasted for 24 hours. Half an hour after premedication (azaperon $8 \mathrm{mg} / \mathrm{kg}$, ketamine $\mathrm{HCl} 10 \mathrm{mg} / \mathrm{kg}$ ) anesthesia was induced with halothane via a face mask (4\%). Anesthesia was maintained with a nitrousoxide, oxygen (1:2), halothane $(0.8 \%)$ mixture. Lactated Ringer's solution $(500-1000 \mathrm{ml})$ was given during operation. Via an ear vein ampicillin $(25 \mathrm{mg} / \mathrm{kg}$ ) was given as antimicrobial prophylaxis. The neck, thorax, and abdomen were prepared for aseptic surgery. Catheters were inserted in the carotid artery and the portal vein as described previously (Van Berlo 1988). Via a direct approach the hepatic vein was cannulated. A gastrostomy catheter was inserted via a pursestring suture high in the stomach. All catheters were passed subcutaneously to the animal's back where the free ends lay behind the scapula. The outer end was not fixed to the skin, allowing the catheter to be gradually pulled through the skin with growth. An electromagnetic flowprobe (Skalar ${ }^{R}$, Delft, The Netherlands) of suitable size was mounted on the portal vein to allow flow measurements. To obtain zero flow measurement an insufflatable balloon was placed at $1 \mathrm{~cm}$ distal from the flowprobe. Postoperatively the animals were placed in isolated heated cages to prevent chilling. The catheters were filled with heparinized saline, refreshed after blood sampling or twice a week. No other anticoagulant medication was given. The pigs received a canvas harness to protect the catheters, and to allow easier handling of the animals. 


\subsubsection{Experiments.}

Catheter insertion was carried out at least one week prior to experimentation. In all experiments pigs were starved for 16 hours. In the first experiment blood was sampled before $(t=0)$ and after ingestion of $400 \mathrm{ml}$ erythrocytes $(80.6 \mathrm{~g}$ protein, < $50 \mathrm{Kcal}$ ), according to a protocol described previously (Van Berlo 1988), on $\mathrm{t}=1,2,3,4,6$, and 8 hours. Following at least two days recovery with normal meals the same procedure was repeated with an isonitrogenous, $i$ socaloric isoleucine enriched erythrocyte meal $(375 \mathrm{ml}, 10 \mathrm{~g}$ Ile, $<50 \mathrm{Kcal}$, $80.6 \mathrm{~g}$ protein). Flow measurements were also performed on various days with different meals in the conscious, unrestrained, conditioned animals. In all experiments each animal served as its own control.

\subsubsection{Analyses.}

Blood samples were immediately placed in ice and transferred to the laboratory. After hematocrit determination the heparinized blood was centrifuged for ten minutes at four degrees centigrade. Plasma was frozen to $-70^{\circ} \mathrm{C}$ until determination of ammonia, urea, and aminograms. Ammonia was analyzed using an automated (Cobas-Bio, Roche ${ }^{\text {Ph }}$ ) enzymatic method (Sigma Ammonia Kit) according to DaFonseca Wollheim (DaFonseca Wollheim 1974; Janssen 1987, 1988). Urea was determined with an automated (Cobas-Bio, Roche ${ }^{\text {F) }}$ enzymatic method (Bio Merieux Testkits) according to Hallett (1971) and Gutman (1974). Amino acids were analyzed with a HPLC employing opthaldialdebyde precolumn derivatization (Andrews 1987; Godel 1984). Lactate was determined according to the method of Noll (1974) on a centrifugal analyzer (Cobas Bio, Roche $^{\AA}$ ) using Boehringer testkits (149993).

\subsubsection{Calculation and statistics.}

Substrate flux across an organ can be derived by multiplication of the concentration difference across that organ times flow. For the bowel the arterial concentration was subtracted from the portal concentration (PA; in $\mu \mathrm{mol} / \mathrm{L}$ ). For the splanchnic region (including liver) this difference is calculated by subtracting the arterial concentration from the hepatic concentration (HA: in $\mu \mathrm{mol} / \mathrm{L}$ ). The concentration across the liver depends on the ratio of portal and arterial blood entering the liver. Assuming that the portal part is about $80 \%$ and the arterial part about $20 \%$, the concentration across the liver (DL) can be derived from hepatic minus arterial concentration minus 0.8 times the portal minus arterial concentration. Multiplication of PA and portal flow gives the production/utilization across the bowel in $\mu$ mols over time. Multiplication of HA and flow (portal and arterial) across the liver gives the total splanchnic production or utilization. As we are still developing reliable hepatic flow measurements the hepatic flow is estimated as the sum of the portal flow measured and data from the literature (hepatic artery flow is $20 \%$ of the portal flow) (Tranquilli 1982; Elwyn 1968). The difference in production between splanchnic (SPL) and bowel (BOW) is the production c.q. utilization of the liver (LIV). Results are 
expressed in mean \pm sem. Statistical analysis was carried out by $t$-test, $\mathrm{p}<0.05$ being considered significant.

\subsubsection{Results.}

\subsubsection{Blood flow rates.}

The mean portal flow rate during the postprandial period was not significantly influenced by food intake or type of regimen (pigfood: $44.3 \pm 2.4 \mathrm{ml} / \mathrm{min} / \mathrm{kg}$; blood constituents: $39.5 \pm 1.6 \mathrm{ml} / \mathrm{min} / \mathrm{kg} ; \mathrm{n}=10$ ). Animal position in this experimental design influenced splanchnic blood flow making it difficult to detect flux differences following food ingestion. We therefore measured mean flow over the total period of study $(6-8 \mathrm{~h})$.

\subsubsection{Ammonia levels (figure la, table 1).}

In the fasting state $(t=0)$ portal values $(174 \pm 14 \mu \mathrm{mol} / \mathrm{L})$ always exceeded arterial levels $(53 \pm 11 \mu \mathrm{mol} / \mathrm{L})$. Hepatic vein levels $(44 \pm 4 \mu \mathrm{mol} / \mathrm{L})$ equalled systemic levels. Following the erythrocytes meal significantly higher portal ammonia levels were observed (max: $\mathrm{t}=6 \quad 444 \pm 34 \mu \mathrm{mol} / \mathrm{L}$ ), resulting in a total production (after 8 hours) of $127 \pm 7 \mathrm{mmol}$. Throughout this time hepatic extraction equalled $118 \pm 9 \mathrm{mmol}$. Following the isoleucine enriched erythrocyte meal maximal portall levels $(t=3: 371 \pm 61 \mu \mathrm{mol} / \mathrm{L})$ were significantly higher compared to fasted levels. Total bowel production equalled $106 \pm 34 \mathrm{mmol} / 8$ hours. Hepatic extraction was $154 \pm 18 \mathrm{mmol} / 8$ hours. The differences observed between erythrocytes and erythrocytes enriched with isoleucine did not reach significance.

\subsubsection{Urea levels (figure $1 b$, table 1 ).}

After 16 hours starvation urea levels ranged between 2.6 and $3.3 \mathrm{mmol} / \mathrm{L}$. Following the erythrocytes meall levels increased to $6.8 \mathrm{mmol} / \mathrm{L}$ by $\mathrm{t}=8$, not reaching a maximum. Following the isoleucine enriched erythrocytes meal urea produced rose to $6.1 \mathrm{mmol} / \mathrm{L}$. Portal and hepatic blood samples showed similar figures. As the difference in concentration between systemic and portal or hepatic vein is in the order of micromoles, the enzymatic method used was unable to detect these differences. Therefore total bowel and liver production were not calcullated. Our experimental setup did not allow us to measure total urinary excretion.

\subsubsection{Amino acid levels.}

Alpha-amino-nitrogen (figure $1 c$, table 1 ).

In all experiments $(n=20)$, the blood levels of the sum of amino acids measured after 16 hours of starvation were of the same order of magnitude in the portal $(2773 \pm 129 \mu \mathrm{mol} / \mathrm{L})$ and arterial blood $(2906 \pm 168 \mu \mathrm{mol} / \mathrm{L})$. Following the erythrocyte meal amino acid levels rapidly increased reaching maximum 
values which were higher in the portal $(t=1: 5428 \pm 665 \mu$ mol/L) than in the arterial $(\mathrm{t}=1: 4414 \pm 490 \mu \mathrm{mol} / \mathrm{L})$ and hepatic blood $(\mathrm{t}=1: 4456 \pm 377 \mu \mathrm{mol} / \mathrm{L})$. Total bowel $\alpha$-amino-nitrogen production was $168 \pm 57 \mathrm{mmol}$ for the 8 hours following the erythrocyte ingestion. During this period the liver extracted $158 \pm 75 \mathrm{mmol} \alpha$-amino-nitrogen. Following the isoleucine enrichment portal values increased to $6255 \pm 624 \mu \mathrm{mol} / \mathrm{L}(\mathrm{t}=3)$, significantly higher than the systemic level $(5553 \pm 620 \mu \mathrm{mol} / \mathrm{L})$. Hepatic levels rose to $6009 \pm 743 \mu \mathrm{mol} / \mathrm{L}$. Total bowel production was $148 \pm 78 \mathrm{mmol} / 8$ hours, while the liver extraction was $77 \pm 151$ mmols during this time.

\section{Glutamine (figure 2a, table 1).}

Fasting systemic glutamine levels $(369 \pm 20 \mu \mathrm{mol} / \mathrm{L})$ were always higher than portal values $(323 \pm 19 \mu \mathrm{mol} / \mathrm{L}$ ). Fasting hepatic levels were $352 \pm 19 \mu \mathrm{mol} / \mathrm{L}$. Following the erythrocyte meal the porta-arterial difference in glutamine concentration (utilization) by the bowel was between 20 and $33 \mu \mathrm{mol} / \mathrm{L}$. By 8 hours $13.1 \pm 1.5 \mathrm{mmol}$ were utilized. During this period the liver produced $6.9 \pm 3.0 \mathrm{mmoll}$ of glutamine. Following the isoleucine enriched erythrocyte meal the porta-arterial difference was between -8 and $-36 \mu \mathrm{mol} / \mathrm{L}$. Net bowel production was $7.6 \pm 2.3 \mathrm{mmol}$ over the 8 hour period. The liver produced $3.5 \pm 5.2$ mmol during this time.

\section{Alanine (figure $2 b$, table 1 ).}

In the fasting state arterial levels $(192 \pm 22 \mu \mathrm{mol} / \mathrm{L})$ of alanine were equal to portal $(186 \pm 19 \mu \mathrm{mol} / \mathrm{L})$ and hepatic $(193 \pm 17 \mu \mathrm{mol} / \mathrm{L})$ levels. Following the erythrocyte and the isoleucine enriched meals a significant porta-arterial difference of alanine was observed. Following the erythrocyte meal intestinal production equalled $39.9 \pm 8.9$ mmols by 8 hours. Following the isoleucine enriched meal $25.3 \pm 3.6 \mathrm{mmol}$ alanine were produced in the same period. The liver extracted $37.6 \pm 12.1 \mathrm{mmol}$ of alanine following the erythrocyte meal and $29.6 \pm 40.5 \mathrm{mmol}$ in the 8 hours following the isoleucine enriched meal.

\section{Glutamate (figure $2 c$, table 1).}

In the fasting state arterial levels $(239 \pm 44 \mu \mathrm{mol} / \mathrm{L}$ ) of glutamate were equal to hepatic $(236 \pm 54 \mu \mathrm{mol} / \mathrm{L})$ and portal $(224 \pm 44 \mu \mathrm{mol} / \mathrm{L})$ levels. Following the erythrocyte and the isoleucine enriched meals a significant porta-arterial difference of glutamate was observed. Following the erythrocyte meal intestinal production equalled $0.8 \pm 2.2 \mathrm{mmols}$ by 8 hours. In the same period $1.4 \pm 1.5 \mathrm{mmol}$ glutamate were produced following the isoleucine enriched meal. Liver extracted $11.7 \pm 11.5 \mathrm{mmol}$ of glutamate during the 8 hours following the erythrocyte meal, and $5.6 \pm 12.8 \mathrm{mmol}$ following the enriched meal. 


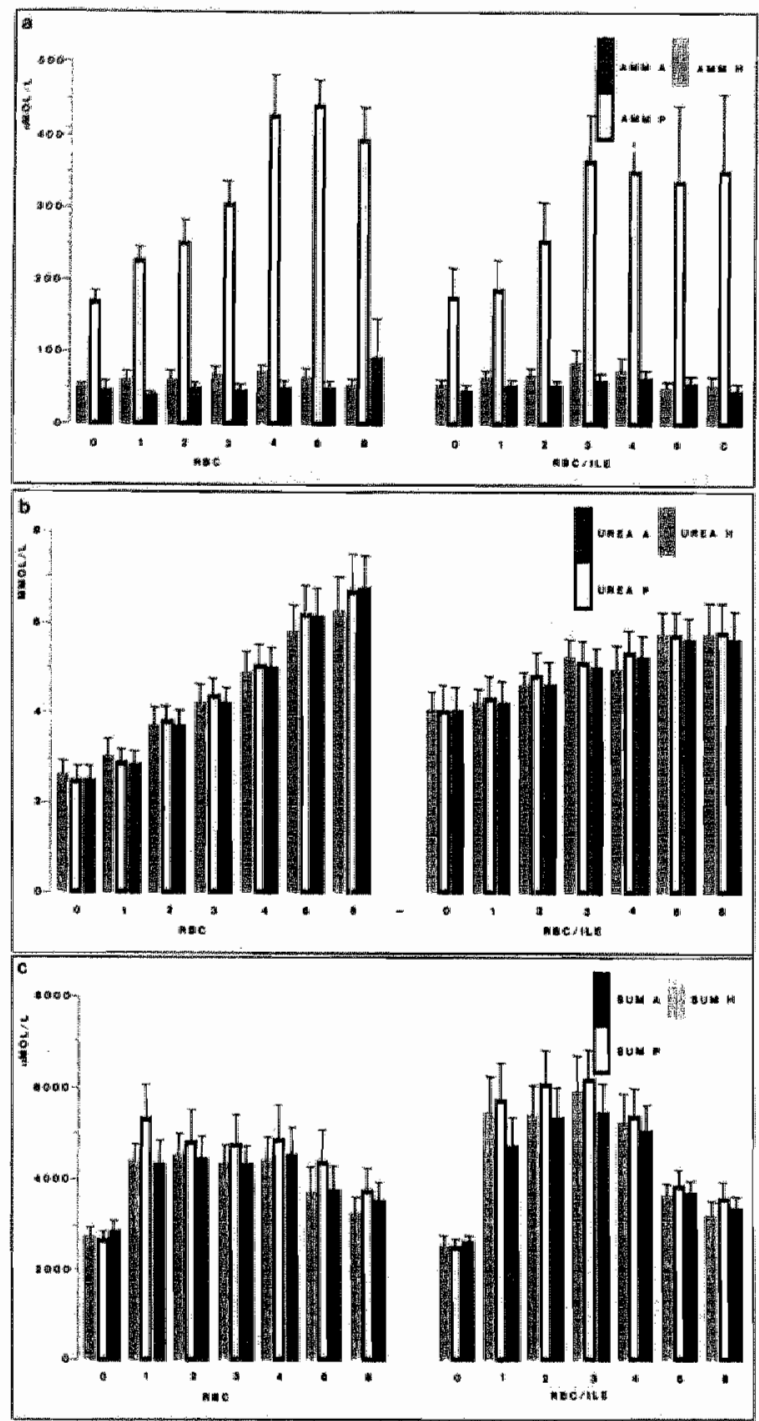

Figure 1 Plasma ammonia (1a), urea (1b), and $\alpha$-amino-nitrogen (1c) concentrations $(\mu \mathrm{mol} / \mathrm{L}$; mean \pm sem) with time after an erythrocyte meal ( $\mathrm{RBC}_{\mathrm{i}} 400 \mathrm{ml}, 80.6 \mathrm{~g}$ protein) and after an isoleucine enriched erythrocyte meal (RBC/LE; $375 \mathrm{ml}, 10 \mathrm{~g}$ isoleucine, 80.6 protein). $\mathrm{A}=$ arterial; $\mathbf{P}=$ portal; $\mathbf{H}=$ hepatic. 


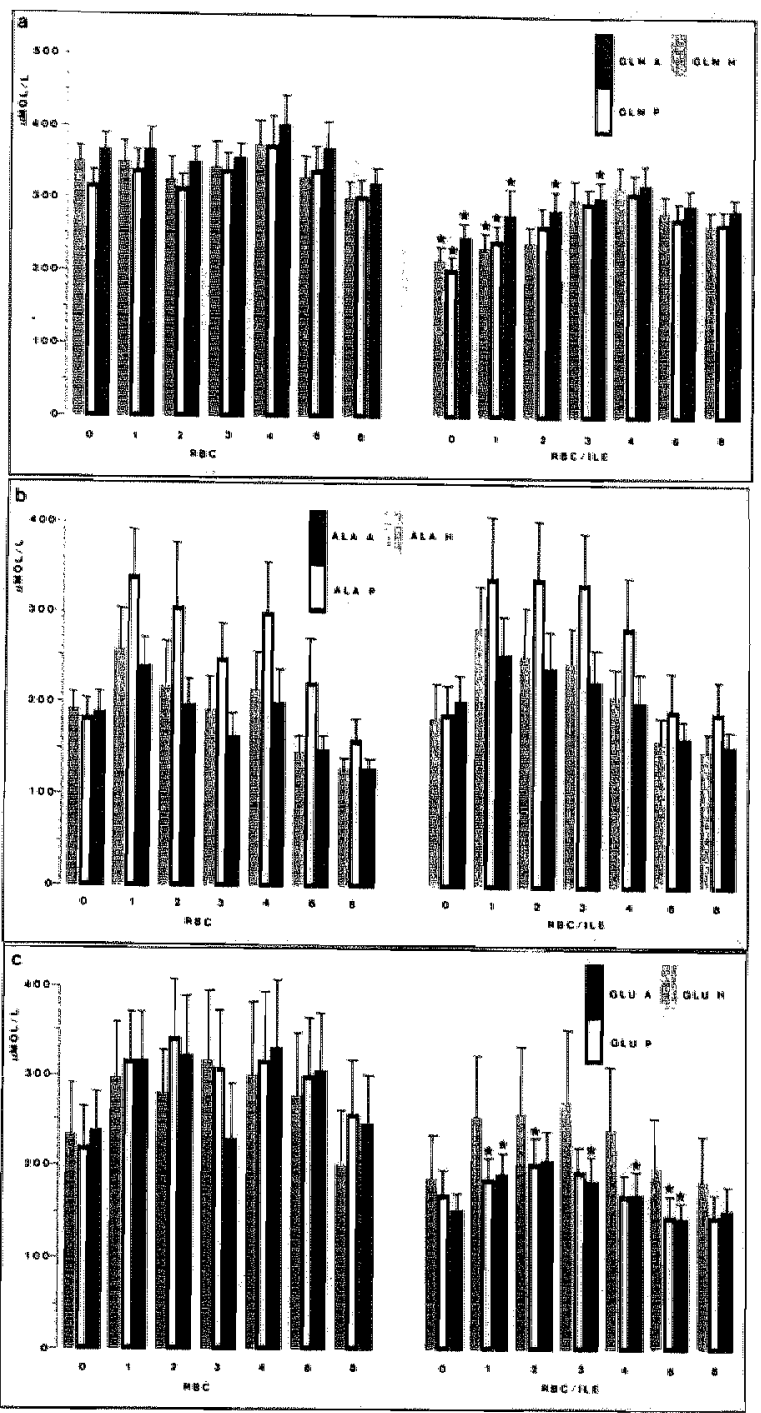

Figure 2 Plasma glutamine (2a), alanine (2b), and glutamate (2c) concentrations ( $\mu$ mol/L; mean \pm sem) with time after an erythrocyte meal (RBC $400 \mathrm{ml}, 80.6 \mathrm{~g}$ protein) and after an isoleucine enriched erythrocyte meal (RBC/LE; $375 \mathrm{ml}, 10 \mathrm{~g}$ isoleucine, $80.6 \mathrm{~g}$ protein). $\mathrm{A}=$ arterial; $\mathrm{P}=$ portal; $\mathrm{H}=$ hepatic. 


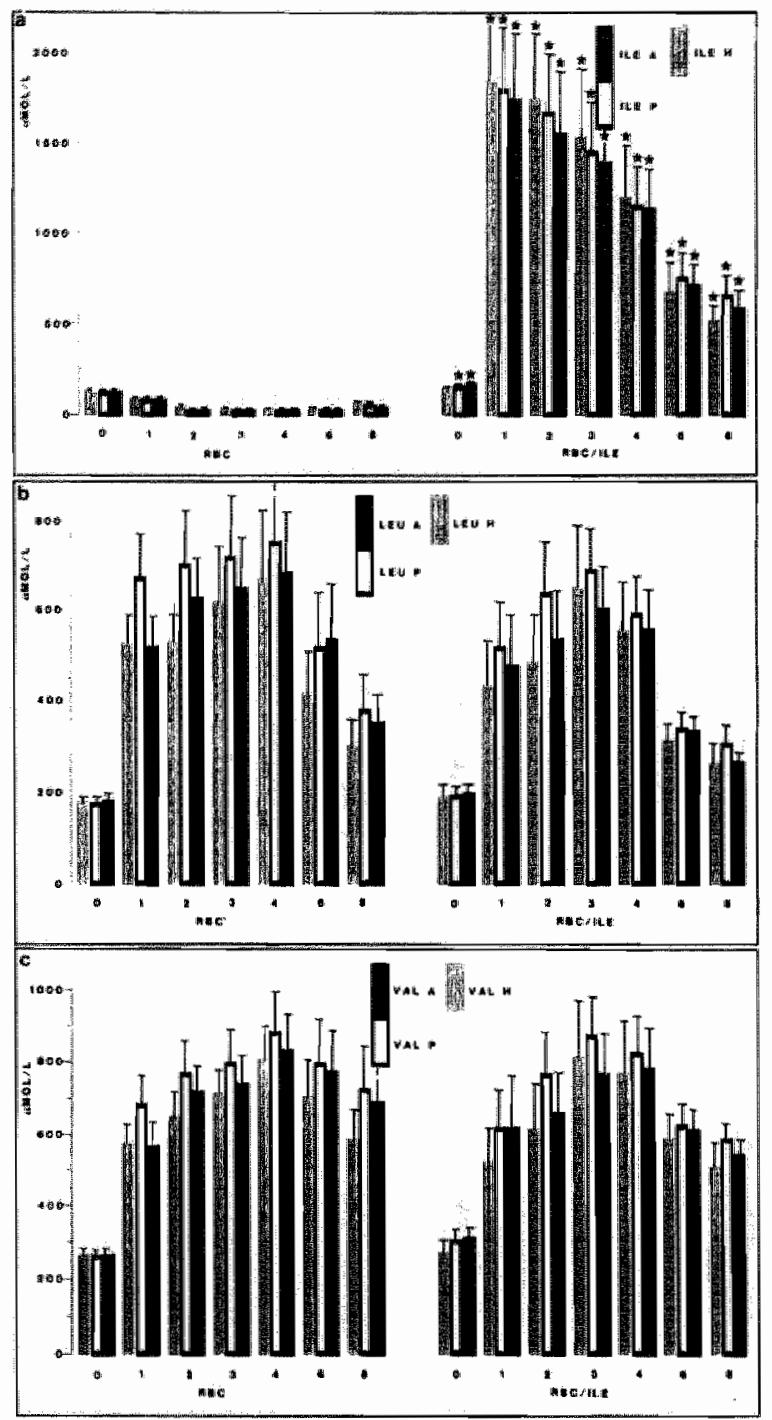

Figure 3 Plasma isoleucine (3a), leucine (3b), and valine (3c) concentrations $\left(\mu \mathrm{mol} / \mathrm{L}_{\text {; }}\right.$ mean \pm sem) with time after an exythrocyte meal (RBC; $400 \mathrm{mll}, 80.6 \mathrm{~g}$ protein) and after an isoleucine enriched erythrogte meal (RBCILE; $375 \mathrm{ml}, 10 \mathrm{~g}$ isoleucine, $80.6 \mathrm{~g}$ protein). $\mathbf{A}=$ arterial; $\mathbf{P}=$ portal; $\mathbf{H}=$ hepatic. 


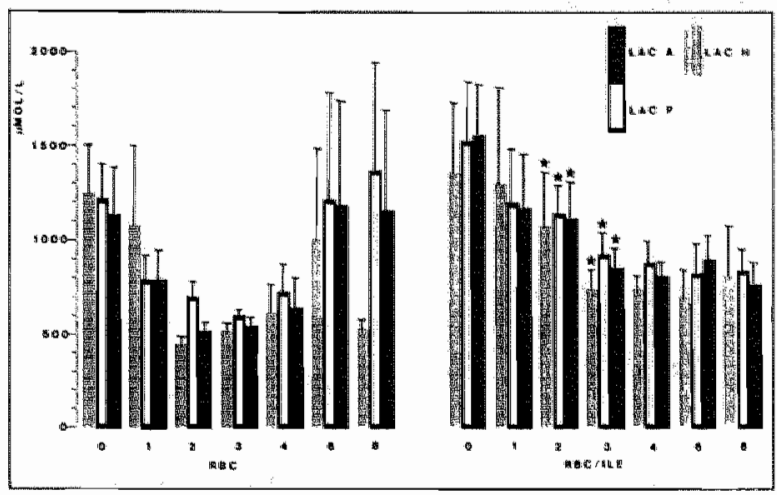

Figure 4 Plasma lactate concentrations (mmol/L; mean \pm sem) with time after an erythrocyte meal (RBC; $400 \mathrm{ml}, 80.6 \mathrm{~g}$ protein) and after an isoleucine enriched erythrocyte meal (RBCMLE; 375 $\mathrm{ml}, 10 \mathrm{~g}$ isoleucine, $80.6 \mathrm{~g}$ protein). $\mathrm{A}=$ arterial $^{\prime} \mathrm{P}=$ portal; $\mathrm{H}=$ hepatic.

Branched chain amino acids.

Isoleucine (figure $3 a$, table 1).

In the fasting state arterial levels $(150 \pm 13 \mu \mathrm{mol} / \mathrm{L})$ of isoleucine were equal to portal $(145 \pm 10 \mu \mathrm{mol} / \mathrm{L})$ and hepatic $(142 \pm 12 \mu \mathrm{mol} / \mathrm{L})$ levels. Following the erythrocyte meal almost no porta-arterial difference of isoleucine was observed. Following the erythrocyte meal intestinal production equalled $1.6 \mathrm{mmols}$ by 8 hours. Isoleucine enriched erythrocytes produced porta-arterial differences of 59 $\mu \mathrm{mol} / \mathrm{L}$. Following the isoleucine enriched meal $12 \mathrm{mmol}$ isoleucine were produced by the bowel during the 8 hours study period. The liver became an organ of isoleucine utilization (1.4 mmol during 8 hours) after the erythrocyte meal. Following the enriched meal the liver became an organ of isoleucine generation $(\mathrm{t}=8$; net extraction $-0.8 \mathrm{mmol})$.

Leucine (figure $3 b$, table 1).

In the fasting state arterial levels $(190 \pm 12 \mu \mathrm{mol} / \mathrm{L})$ of leucine were equal to portal $(185 \pm 10 \mu \mathrm{mol} / \mathrm{L})$ and hepatic $(187 \pm 13 \mu \mathrm{mol} / \mathrm{L})$ levels. Following the erythrocyte meal a significant increase was observed in portal $(759 \pm 159 \mu \mathrm{mol} / \mathrm{L})$, systemic $(687 \pm 128 \mu \mathrm{mol} / \mathrm{L})$ and hepatic $(672 \pm 147 \mu \mathrm{mol} / \mathrm{L})$ levels, reaching its maximum by $\mathrm{t}=4$. Intestinal production equalled $24 \mathrm{mmol} / 8$ hours, while the liver extracted $22.7 \mathrm{mmol} / 8$ hours. Following the enriched formula $6 \mathrm{mmol}$ were extracted by the liver within 8 hours, during which intestinal production was $13.7 \mathrm{mmol}$.

Valine (figure $3 c$, table 1 ). 
In the fasting state arterial levels $(276 \pm 14 \mu \mathrm{mol} / \mathrm{L})$ of valine were equal to portal $(271 \pm 13 \mu \mathrm{mol} / \mathrm{L})$ and hepatic levels $(275 \pm 18 \mu \mathrm{mol} / \mathrm{L})$. Following the erythrocyte meal levels increased and reached a maximum by $t=4$ (arterial: $844 \pm 95 \mu \mathrm{mol} / \mathrm{L}$; portal: $892 \pm 108 \mu \mathrm{mol} / \mathrm{L}$; hepatic: $810 \pm 90 \mu \mathrm{mol} / \mathrm{L}$ ). Intestinal production of valine was $22.6 \mathrm{mmol}$ for the 8 hours after the erythrocytes meal and 13.4 mmols after the enriched formula. The liver extracted $17.7 \mathrm{mmol}$ versus $4.7 \mathrm{mmol}$ of valine in the 8 hour period following the erythrocyte and isoleucine enriched meals respectively.

Lactate (figure 4, table 1).

In the fasting state arterial levels $(1.14 \pm 0.25 \mathrm{mmol} / \mathrm{L})$ equalled portal $(1.23 \pm 0.18 \mathrm{mmol} / \mathrm{L})$ and hepatic levels $(1.26 \pm 0.25 \mathrm{mmol} / \mathrm{L})$. Following the erythrocyte meal lactate levels decreased, reaching a minimum by $t=3 \quad(0.5-0.6$ mmol/L). The bowel produced 34 mmols during the 8 hours study period. Throughout this time the liver extracted 126 mmols lactate. Following the isoleucine enriched formula, the bowel produced 22 mmols of lactate during 8 the hours, while the liver extracted 7 mmols.

\subsubsection{Discussion.}

Recently we reported a greater rise in ammonia liberation following ingestion of blood than after an isonitrogenous pigmeal (Van Berlo 1988). In the present study we studied the effect of the administration of blood enriched with isolencine. Intestinal ammonia production was reduced after a blood meal enriched with isoleucine, but significance was not reached. After bloodmeals without isoleucine enrichment we found hyperaminoacidemia, increased urea levels and extremely low isoleucine levels. We hypothesized that these findings were the result of the complete lack of isoleucine in the hemoglobin molecule. Trends were noted in accordance with our hypothesis. Notably the isoleucine enriched diet depressed urea levels and ammonia production in the gut. Because these trends were not significant they furnish no firm support for the hypothesis. Our findings do not reject the hypothesis however, because the extremely elevated isoleucine levels indicate that too much isoleucine was added. Our calculation was based upon a comparison with normal pig food, while we should have calculated the amount necessary to meet daily requirements. This excess of isoleucine potentially leads to competition for transport with valine and leucine. Under the experimental in vivo conditions of this study electromagnetic flowmeasurements exhibit substantial fluctuations. As a consequence we must be careful with the interpretation of fluxes calculated on the basis of such measurements. Despite the fact that the results of this study are inconclusive an interesting finding was the difference in the uptake of lactate by the liver. As lactate is a major substrate for bepatic gluconeogenesis this finding may reflect a difference in gluconeogenesis. Apperently isoleucine enrichment decreases lactate production in the gut and simultaneously diminishes lactate uptake cq gluconeogenesis in the liver. Consistent with this finding is diminished 
hepatic extraction of alanine, another important substrate for gluconeogenesis, following isoleucine enrichment. A potential explanation for these findings is that a bloodmeal without isoleucine furnishes protein of low biological value which induces net protein degradation. This leads to increased ammoniagenesis and ureagenesis, but also furnishes carbonskeletons. One way of dealing with this carbon is to produce glucose which subsequently can be used for glycogen or fat synthesis. Other amino acids showed moderate differences in the individual amino acid levels. They are likely to be influenced by fluctuations in flow as indicated earlier. Glutamine and glutamate levels decreased after enrichment. Indicative of what is happening may be that despite ingestion of equal amounts of leucine and valine with both regimens, more valine and leucine become visible in the portal vein. This could be explained either by malabsorption after isoleucine enrichment or by increased degradation of the intestinal wall.

Intestine Liver

\begin{tabular}{|c|c|c|c|c|c|c|c|c|}
\hline & $\mathbf{E}$ & & I & & $\mathrm{E}$ & & I & \\
\hline ammonia 1 & $127 \pm$ & 27 & $106 \pm$ & 34 & $-118 \pm$ & 9 & $-154 \pm$ & 18 \\
\hline $\begin{array}{l}\alpha \text {-amino- } 1 \\
\text { nitrogen }\end{array}$ & $168 \pm$ & 57 & $148 \pm$ & 78 & $-158 \pm$ & 75 & $-77 \pm$ & 151 \\
\hline glutamine & $-13 \pm$ & 2 & $-8 \pm$ & 2 & $7 \pm$ & 3 & $3 \pm$ & 5 \\
\hline alanine & $40 \pm$ & 9 & $25 \pm$ & 14 & $-38 \pm$ & 12 & $-30 \pm$ & 40 \\
\hline glutamate & $1 \pm$ & 2 & $1 \pm$ & 1 & $-12 \pm$ & 11 & $6 \pm$ & 13 \\
\hline isoleucine & $2 \pm$ & 1 & $12 \pm$ & 4 & $-1 \pm$ & 1 & $-1 \pm$ & 6 \\
\hline leucine & $24 \pm$ & 8 & $14 \pm$ & 7 & $-23 \pm$ & 8 & $-6 \pm$ & 6 \\
\hline valine & $23 \pm$ & 7 & $13 \pm$ & 6 & $-18 \pm$ & 7 & $-5 \pm$ & 13 \\
\hline lactate & $34 \pm$ & 11 & $21 \pm$ & 16 & $-126 \pm$ & 71 & $-7 \pm$ & 82 \\
\hline
\end{tabular}

Table 1: Intestinal and hepatic substrate production $(+)$ or utilization $(-)$ during the 8 hours following ingestion of erythrocytes (E) or isoleucine enriched erythrocytes (I), derived from the difference in concentrations across the organ times flow in mmol/8 hours (mean \pm sem). 


\section{CHAPTER 4}

\section{PORCINE INTESTINAL AMMONIA LIBERATION: INFLUENCE OF FOOD INTAKE, LACTULOSE, AND NEOMYCIN TREATMENT.'}

\subsection{Abstract.}

Lactulose and neomycin have, besides influencing ammonia production by the intestinal flora, been proposed to reduce intestinal glutamine dependent ammonia formation. To test this hypothesis we determined the effects of lactulose and neomycin on the release or uptake of ammonia, urea, and amino acids across the intestine in freely moving healthy pigs. Blood was sampled from catheterized piglets $(20 \pm 0.8 \mathrm{~kg} ; \mathrm{n}=6)$, one hour before, and one, two, three, and six hours following a standard pig meal $(750 \mathrm{~g}, 12 \%$ protein). Lactulose or neomycin therapy was then commensed for one week and the blood sampling procedure repeated. Electromagnetic portal and small bowel flow measurements were carried out in separate groups of pigs. Flow measurements were independent of food type ingested. No significant alterations in flow could be detected during the six hour study period. Portal and porta-arterial ammonia differences were significantly diminished following both lactulose $(-20 \%)$ and neomycin $(-35 \%)$ treatment. ot-Amino-nitrogen absorption decreased in both groups as compared to controls, although this did not reach significance. Systemic and portal glutamine levels and intestinal glutamine utilization were significantly lower in the treatment groups. Citrulline and glutamate levels and intestinal production decreased after treatment. In this in vivo model ammonia liberation following protein meals decreased in animals pretreated with lactulose or neomycin. The observed decrease in systemic glutamine and consequent decrease in intestinal glutamine utilization may contribute to a reduction of endogenous ammonia formation by the gut wall. Decreased absorption from the gut of $\alpha$-amino-nitrogen may however also contribute to a decrease in ammonia production. These results confirm earlier in vitro and in vivo observations in Wistar rats. The mechanisms by which neomycin and lactulose lower systemic glutamine levels however remain to be clarified.

\subsection{Introduction.}

The mechanism of action of lactulose and neomycin in lowering the systemic ammonia levels in patients with liver insufficiency is not clear. Ammonia production by the gut, which enters the portal circulation is largely thought to be generated in the colon. The production of ammonia is generally attributed to the metabolism of urea, amino acids, luminal derived protein, and desquamated

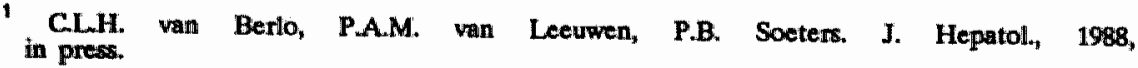


epithelial cells by the colonic flora (Walser 1959; Wolpert 1970). In recent years greater emphasis has been put on the generation of ammonia by the intestinal mucosa, independent of the luminal flora. Glutamine, derived from blood or the lumen, is the main precursor of ammonia in the small intestine (Windmueller 1974; Weber 1979; Matsutaka 1973; Van Leeuwen 1984). Its breakdown results in production of ammonia, citrulline, alanine, and glutamate. In the treatment of porta-systemic encephalopathy lactulose and meomycin are known to decrease plasma ammonia levels (Bircher 1966; Dawson 1957). Recently we reported a significant in vitro and in vivo decrease in intestinal metabolic ammonia production, in normal and germfree Wistar rats, after lactulose and neomycin treatment (Van Leeuwen 1984, 1985). To confirm these findings, we developed a large animal model, allowing measurement of intestinal blood flow, and allowing sequential blood sampling. In this model we will quantitate the effect of lactulose and neomycin on ammonia production following protein loads.

\subsection{Material and methods.}

\subsubsection{Animals.}

Female crossbred (Yorkshire $x$ Dutch Landrace) piglets $(n=6)$ of about $20 \pm 0.8 \mathrm{~kg}$ (mean $\pm \mathrm{sem}$ ) were used and individually housed inside in galvanized bar runs ( $2 \times 3$ meters) equipped with an automatic watering device. Animals were placed in the pen and acclimatized to their new surroundings for at least three days prior to surgery. In this period they got acquainted to the investigator and to a small movable cage $(0.9 \times 0.3 \times 0.5 \mathrm{~m})$ used during blood sampling. The animals were treated according to the guidelines of the European convention for the protection of vertebrate animals used for experimental and other scientific purposes.

\subsubsection{Surgical procedures.}

Animals were fasted for 24 hours. Half an hour following premedication (azaperon $0.8 \mathrm{mg} / \mathrm{kg}$, ketamine $\mathrm{HCl} 10 \mathrm{mg} / \mathrm{kg}$ ) anesthesia was induced with thiopental sodium $(25 \mathrm{mg} / \mathrm{kg})$ via an ear vein. Anesthesia was maintained with a nitrousoxide, oxygen (1:2), halothane (0.8\%) mixture. Lactated Ringer's solution $(500-1000 \mathrm{ml})$ was given during operation. Via the ear vein ampicillin (25 $\mathrm{mg} / \mathrm{kg}$ ) was given as antimicrobial prophylaxis. The neck, thorax and abdomen were prepared for aseptic surgery. Catheters were inserted in the carotid artery, the portal vein, the superior mesenteric vein and passed subcutaneously to the animal's back where the free ends lay behind the scapula. Furthermore the free end was not fixed to the skin, so that the catheter could gradually pull through the skin with growth. Postoperatively pigs were placed in isolated heated cages to prevent chilling. The catheters were filled with heparinized saline, refreshed following blood sampling or twice a week. No other anticoagulant medication was given. Pigs got a canvas harness to protect the catheters, enabling easier handling of the animals. In a separate group of pigs $(n=10)$ elec- 
tromagnetic flowprobes (Skalar ${ }^{R}$, Delft, The Netherlands) and insufflatable balloons were mounted on the portal vein, enabling mean portal fllow measurements. In another group $(\mathrm{n}=3)$ only small bowel flow measurements (superior mesenteric artery minus colonic artery) were performed.

\subsubsection{Experiments.}

Experiments were started after a recovery of at least three days. Pigs were fed twice a day. In the first experiment the pigs were starved for 16 hours. Blood was sampled from the three catheters for determination of ammonia, urea, and amino acids one hour before, one, two, three, and six hours following a standard pigmeal ( $750 \mathrm{~g}, 12 \%$ proteiln; composition and amino acid content in table 1).

Pig food composition

\begin{tabular}{|c|c|c|c|c|c|}
\hline & & & $\mu \mathrm{mol} / \mathrm{g}$ & & $\mu \mathrm{mol} / \mathrm{g}$ \\
\hline soy & 8.3 & Pho & 0.0 & Cyss & 12.0 \\
\hline sunflowerseeds & 7.5 & Tau & 0.6 & Met & 19.3 \\
\hline maizglutenmeal & 10.0 & Asp & 127.3 & Ile & 51.1 \\
\hline animalfat & 1.4 & Thr & 60.0 & Leu & 96.3 \\
\hline phosphoric acid & & Ser & 90.0 & Tyr & 31.7 \\
\hline calcium & 0.6 & Asn & 201.5 & Phe & 46.9 \\
\hline chalk & 0.7 & Glu & 1.8 & Orn & 0.3 \\
\hline salt & 0.4 & Gln & nd & Lys & 51.0 \\
\hline lucerne & 5.0 & Pro & 99.7 & His & 28.3 \\
\hline maizmeal & 13.1 & Gly & 129.2 & Arg & 64.8 \\
\hline molasses & 7.5 & Ala & 115.8 & $\mathrm{Nh} 3$ & 6.2 \\
\hline assava & 35.0 & Cit & 0.0 & & \\
\hline wheatgrits & 10.0 & Abu & 0.6 & & \\
\hline premix & 0.5 & Val & 78.8 & & \\
\hline
\end{tabular}

Table 1 Composition and amino acid content of pig food.
Pig food amino acid content $\mu \mathrm{mol} / \mathrm{g}$ $\mathrm{mol} / \mathrm{g}$

193

51.1

31.7

46.9

0.3

28.3

64.8

6.2

Before the second experiment animals were pretreated with lactulose ( $2 \times 60$ g/day Legendal ${ }^{\mathrm{p}}$, crystalline lactulose, Inpharzam, Almere, The Netherlands) for one week, orally mixed in the meals. After a recovery of one week, animals were given neomycin ( $8 \mathrm{~g} /$ day A.U.V. Cuijck, The Netherlands) for 7 days, given with the second meal. After the lactullose and neomycin treatment meals were given and blood was sampled as in the first experiment. The dosages of neomycin and lactulose administered were such that mild diarrhoea was induced. Flow measurements were performed on various days before and during meals, with and without lactulose and neomycin treatment, in the conscious, unrestrained, conditioned animals. For all experiments each animal served as its own control. 


\subsubsection{Analyses.}

Blood samples were immediately put on ice and transferred to the laboratory. After hematocrit determination the heparinized blood was centrifuged for ten minutes at four degrees centigrade. Plasma was frozen to $-70^{\circ} \mathrm{C}$ until determination of ammonia, urea and aminograms. Ammonia was analyzed with an automated (Cobas-Bio, Roche ${ }^{\mathrm{T}}$ ) enzymatic method (Sigma Ammonia Kit) according to DaFonseca Wollheim (DaFonseca Wollheim 1974; Janssen 1988). Urea and amino acids were analyzed on an automated amino acid analyzer (LKB 4400), using lithium buffers (Andrews 1987; Deyl 1986).

\subsubsection{Calculation and' statistics.}

The production or utilization of substrates across an organ can be derived by multiplying the venous-arterial concentration difference across that organ times the flow. For the whole intestine porta-arterial difference was multiplied by the mean portal vein flow. For the small bowel the concentration difference between superior mesenteric vein and artery was multiplied by the mean flow, derived by subtracting colonic artery flow from superior mesenteric artery flow. Results are expressed in mean \pm sem. Statistical analysis was carried out by the unpaired $t$-test level of significance taken at $p<0.05$.

\subsection{Results.}

\subsubsection{Blood flow rates.}

There was no difference in mean blood flow between controls $(40 \pm 3$ $\mathrm{ml} / \mathrm{kg} / \mathrm{min} ; \mathrm{n}=10)$, and animals pretreated with lactulose $(41 \pm 4 \mathrm{ml} / \mathrm{kg} / \mathrm{min}$; $\mathrm{n}=10$ ) and neomycin $(43 \pm 4 \mathrm{ml} / \mathrm{kg} / \mathrm{min} ; \mathrm{n}=10)$. Likewise the mean small bowel flow was similar in all groups (controls: $19 \pm 1 \mathrm{ml} / \mathrm{min} / \mathrm{kg} ; \mathrm{n}=3$; lactulose: $20 \pm 1$ $\mathrm{ml} / \mathrm{kg} / \mathrm{min} ; \mathrm{n}=3$; neomycin: $20 \pm 2 \mathrm{ml} / \mathrm{kg} / \mathrm{min} ; \mathrm{n}=3$ ).

\subsubsection{Ammonia levels (figure la, table 2).}

Inter- and intraassay variations: Interassay variations were obtained by measuring three standard aliquots on the same day under the identical conditions to the samples. For ammonia the standard conentrations used were 58.8-117.6-176.6 $\mu \mathrm{mol} / \mathrm{L}(\mathrm{n}=147)$. The observed results were respectively 59.58-117.31-175.92 $\mu \mathrm{mol} / \mathrm{L}$. Coefficients of variation: $4.06 \%-2.56 \%-2.96 \%$. Intraassay variations were obtained by measuring 20 aliquots of these standards on the same day, under the same conditions. The intraassay variations for these ammonia standards were respectively $3.08-1.78-0.80 \%$. The mean analytical recovery of ammonia was $100 \%$.

In fasting animals $(n=6)$, portal ammonia levels $(165 \pm 18 \mu$ mol/L) always exceeded the arterial levels $(44 \pm 4 \mu \mathrm{mol} / \mathrm{L})$, this difference $(121 \pm 18 \mu \mathrm{mol} / \mathrm{L})$ being significant $(\mathrm{p}<0.001)$. Following the standard pigmeal this difference progressively increased and reached a maximum two to three hours following in- 
gestion of $750 \mathrm{~g}$ standard pigfood and then declined. By $\mathrm{t}=6(220 \pm 11 \mu \mathrm{mol} / \mathrm{L})$ portal ammonia levels were only slightlly higher than the basal level. Following a week of lactulose (L) or neomycin (N) treatment, fasted arterial levels (L:39 $\pm 7 ; \mathrm{N}: 40 \pm 3 \mu \mathrm{mol} / \mathrm{L}$ ) decreased, but this was not significant. Portal values were significantly depressed ( $\mathrm{L}: 139 \pm 38$; $\mathrm{N}: 121 \pm 27 \mu \mathrm{mol} / \mathrm{L}$ ) as was the portaarterial difference (L: $107 \pm 38 ; \mathrm{N}: 81 \pm 25 \mu \mathrm{mol} / \mathrm{L}$ ). Following lactulose or neomycin treatment an equivalent meal as in the first experiment gave rise to significantly less ammonia production (max L: $191 \pm 52 ; \mathrm{N}: 140 \pm 60 \mu \mathrm{mol} / \mathrm{L}$ ). Total intestinal production for the six hours study period was $61.5 \pm 9.3 \mathrm{mmol}$ for the controls, $49.5 \pm 9.9 \mathrm{mmol}$ after lactulose treatment and $40.5 \pm 8.1 \mathrm{mmol}$ after neomycin treatment. Total small bowel ammonia production for the six hour study period was $45.4 \pm 6.4 \mathrm{mmol}$ in the control group, $30.6 \pm 6.1 \mathrm{mmol}$ in the lactulose treated group and $36.4 \pm 7.3 \mathrm{mmol}$ in the neomycin treated group.

\subsubsection{Urea levels (figure 2a).}

In the fasting state arterial urea levels were similar to portal values $(2314 \pm 479$ versus $2689 \pm 308 \mu \mathrm{mol} / \mathrm{L}$ ). Only a slight increase in systemic level was observed following the control meal $(3349 \pm 400 \mu \mathrm{mol} / \mathrm{L}$ ), during which the porta-arterial differences were zero or slightly negative. For the 6 hours study period no maximum was reached. Following lactulose or neomycin treatment no changes were observed.

\subsubsection{Amino acid levels.}

Alpha-amino-nitrogen (figure $2 b$, table 2):

Following 16 hours of fasting total amino acid content of portal $(3090 \pm 362$ $\mu \mathrm{mol} / \mathrm{L})$ and arterial blood $(3060 \pm 252 \mu \mathrm{mol} / \mathrm{L})$ were similar, in all experiments $(n=12)$. Following the control meal, the amino acid levels rapidly increased reaching maximum values which were significantly higher in the portal than in the arterial blood $(4323 \pm 200 \mu \mathrm{mol} / \mathrm{L}$ versus $3530 \pm 151 \mu \mathrm{mol} / \mathrm{L} ; \mathrm{p}<0.01)$. Following a standard meal after one week of neomycin or lactulose treatment, no significant differences were observed in arterial or portal total $\alpha$-amino-nitrogen levels. Control portal $\alpha$-amino-nitrogen production was $159 \pm 39.8 \mathrm{mmol}$ within the six hours study period. Following lactulose and neomycin treatment portal $\alpha$-amino-nitrogen production decreased to $100 \pm 28.8 \mathrm{mmol}$ and $85 \pm 29.5 \mathrm{mmol}$ respectively, these decreases not reaching significance.

\section{Glutamine (figure $1 b$, table 2):}

Fasting systemic glutamine levels $(455 \pm 76 \mu \mathrm{mol} / \mathrm{L})$ were always higher than portal values $(400 \pm 84 \mu \mathrm{mol} / \mathrm{L})$. This net intestinal glutamine utilization was also observed following a standard meal. Net portaarterial differences became less negative during the first three hours, following the standard meal, despite an increase in systemic levels values retained to baseline by $t=6$. Following one week of lactulose or neomycin administration systemic glutamine levels were 
significantly decreased (L:298 $\pm 25 ; \mathrm{N}: 309 \pm 22$ ). Likewise pigmeal induced rises in glutamine levels following neomycin or lactulose were less than in control experiments. Porta-arterial difference was also significantly less at $t=1$ following lactulose and neomycin treatment.

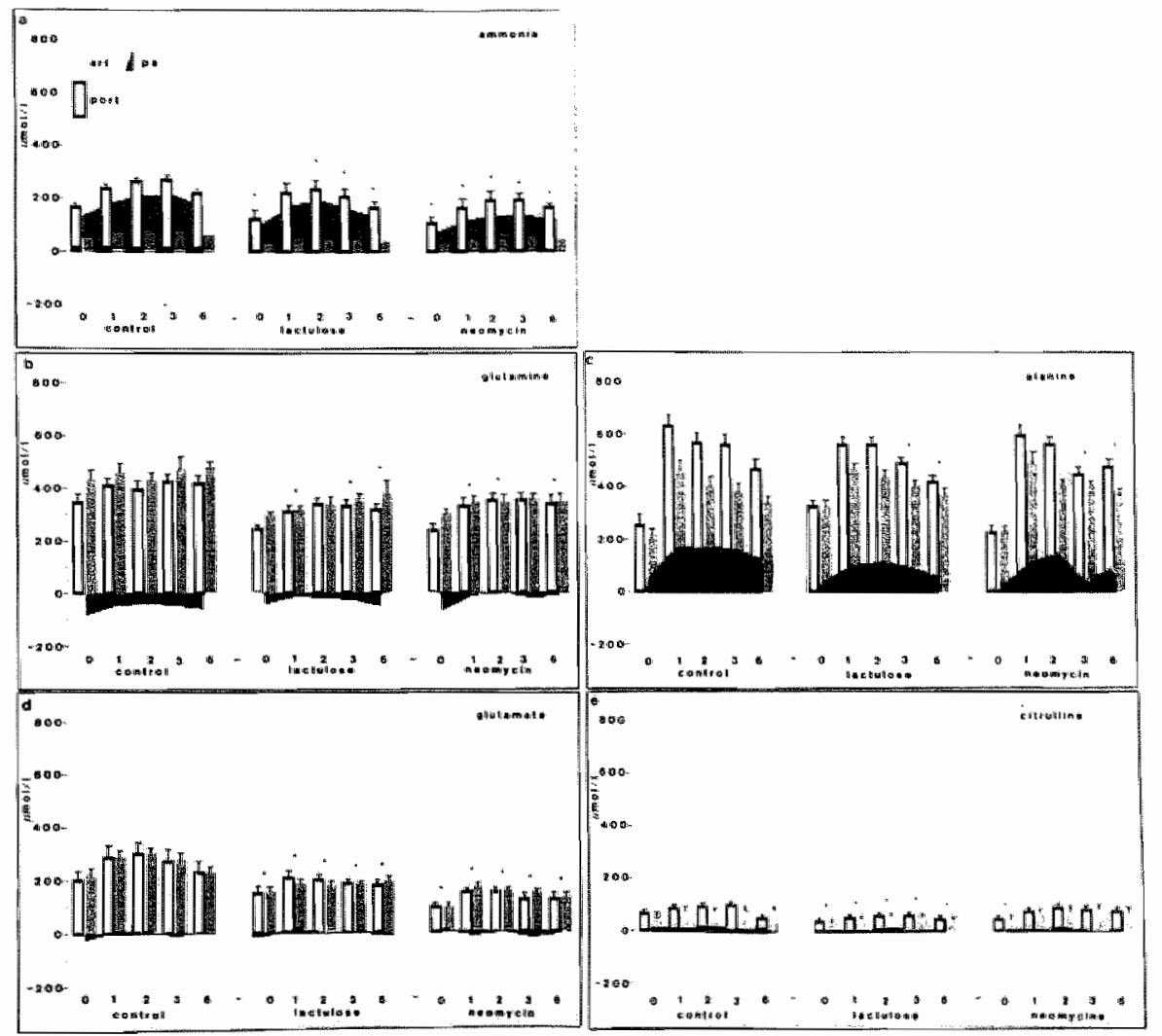

Figure 1 Plasms ammonia (a), glutamine (b), alanine(c), glutamate (d), and citrulline (c) concentrations ( $\mu \mathrm{mol} / \mathrm{L}_{i}$ mean $\left.\pm \mathrm{sem}\right)$ with time pre and post standard meal ingestion $(n=6$ pigs) without (controls) and with lactulose and neomycin treatment, art $=$ arterial, port $=$ portal, pa $=$ portall minus. arterial. * $=p<0.05$ compared to controls. 
Portal alanine levels exceeded arterial levels in the fasting state, while food intake increased the alanine absorption significantly. Following lactulose and neomycin treatment porta-arterial differences were significantly decreased at $t=3$. and $t=6$, giving rise to significantly decreased alanine production (L:27.2 \pm 6.0 mmol; $N: 25.7 \pm 25.7 \mathrm{mmol}$ ) for the six hour study period, in comparison to controls $(47.6 \pm 10.4 \mathrm{mmol})$.

Glutamate (figure 1d, table 2):

Glutamate levels were significantly lower following lactulose or neomycin treatment, compared to control values. Likewise glutamate porta-arterial difference was significantly lower at $\mathrm{t}=0$ following lactulose treatment and at $\mathrm{t}=0,1,2$, 3 , and 6 hours following neomycin treatment.

Citrulline (figure 1e, table 2):

The systemic citrulline levels were significantly smaller at $t=0,1,2,3$, and 6 hours following lactulose treatment and on $t=0,3$, and 6 hours following neomycin treatment. No difference was observed in absorption following treatment, compared to controls.

\subsection{Discussion.}

In the literature protein restriction, and lactulose and neomycin treatment are reported to be beneficial in liver disease because of their ammonia lowering effect (Bircher 1966; Dawson 1957; Greenberger 1977; Uribe 1982, 1985; De Bruijn 1983; Van Leeuwen 1988). Also in humans the food fiber content has been associated with better protein tolerance during liver disease (Uribe 1985). However the rate of portal ammonia generation during these treatments has not been quantitated. The exclusive role of the colonic flora in ammonia generation has been stressed by some authors (Douwes 1987; Editorial 1983, 1987), although a glutamine dependent ammonia formation in the small bowel has been repeatedly demonstrated. In fact this may account for at least $50 \%$ of total splanchnic ammonia production (Windmueller 1974; Weber 1979; Matsutaka 1973; Van Leeuwen 1984; Souba 1985).

In this study we attempted to quantitate the rate of portal and selectively small bowel ammonia production in healthy, freely moving, catheterized animals. In this model differences in blood flow rate following food intake could not be distinguished from alteration in animal position (standing, lying, sitting). Flow measurements were therefore calculated for the total study period. To estimate the ammonia and substrates production rates, mean flow was multiplied by the differences in concentrations across the organs measured. Ammonia production was measured pre and post treatment with and without moderate protein loads. All animals were healthy with normal liver function. The dose of each agent was derived from previous rat experiments (Van Leeuwen 1984) and ad- 
justed for weight and surface area difference. In the rat studies the existence of diarrhea was associated with a better therapeutical effect. In this study each agent produced diarrhea within 2 days. We appriciate however that as neomycin is oto- and nephrotoxic, this dose is not applicable to human clinical practice. As lactulose is non toxic high doses will not limit its clinical application. Dose response curves, evaluating the effect on glutamine dependent ammonia formation, need to be performed. In our study we confirmed the ammonia decreasing properties of lactulose and neomycin treatment in the fasted state. In addition we also demonstrated that protein ingestion generated less ammonia following treatment compared to controls. Small bowel ammonia production accounted for more than $75 \%$ of total intestinal production. This decreased $33 \%$ and $20 \%$ following lactulose and neomycin respectively. As urea concentrations in particular porta-arterial differences were not influenced by the treatment, this decrease in ammonia can not be due to a difference in the hydrolysis of urea. A decrease in the urea pool, as described by Weber $(1979,1981)$, following lactulose treatment, was not found in this study.

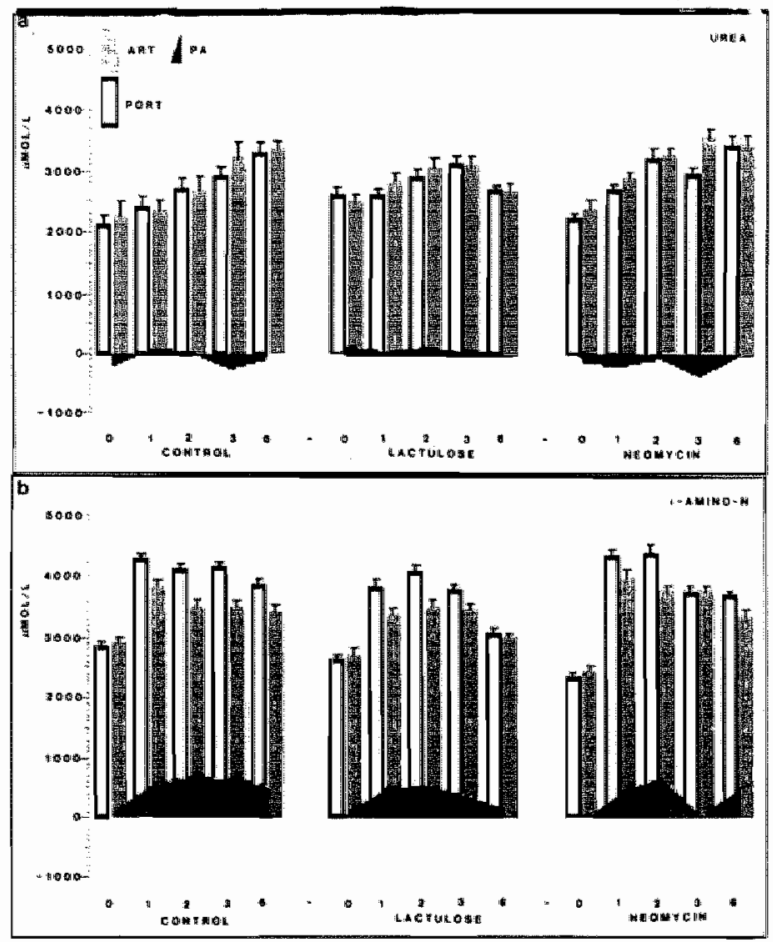

Figure 2 Plasma urea (a) and $\alpha$-amino-nitrogen (b) concentrations ( $\mu$ mol/Li mean \pm sem) with time pre and post standard meal ingestion $(n=6$ pigs) without (control) and with lactulose and neomycin treatment $\mathrm{ART}=$ arterial, $\mathrm{PORT}=$ portal, $\mathrm{PA}=$ portal minus arterial. $=\mathrm{p}<$ 0.05 compared to controls. 
The effects of neomycin have been attributed to a reduction in colonic flora, resulting in decreased bacterial ammonia formation (Imler 1975). The aerobic flora (Enterobacteriaceae) in particular is sensitive to the action of neomycin. Although intestinal flora might be substantially different in PSE patients, it is difficult to conceive that manipulation of this small part of gut flora (approximately 1\%) may achieve an important decrease in ammonia levels. Others proposed a "toxic" effect on enterocytes, resulting in an effect on the permeability of the absorptive membrane (Kessler 1978; Cain 1968). The laxative effect of lactullose has been proposed to result in less substrate for bacteria, hence decreasing ammonia formation (Agostini 1972; Elkington 1969; Vince 1974, 1980). In this study the absorption of total $\alpha$-amino-nitrogen decreased following treatment. Although this decrease was not significant an effect of diminished absorption can not be ruled out. Small bowel ammonia production was significantly decreased following neomycin treatment. It is possible that non-bacterial mechanisms are involved in this process. This confirms earlier in vitro observations in our laboratory that the rate of ammonia produced by isolated enterocytes of normal and germfree rats, was attenuated by addition of neomycin and lactulose (Van Leeuwen 1984, 1985). In rats both treatments decreased on basal glutamine levels. In this study fasting state glutamine utilization was decreased, particularly in the small bowel. As during this process $80 \%$ of the amide nitrogen yields ammonia (Windmueller 1982), a decrease of glutamine utilization results in less ammonia generation. Following protein ingestion glutamine utilization diminished, possibly also secondary to the inhibition of extraction of arterial glutamine by the bowel when glutamine and glutamate are present in the lumen (Windmueller 1975). Nevertheless this net utilization was less following treatment. Intestinal glutamine breakdown results in ammonia, glutamate, citrulline, proline, ornithine, and alanine. Glutamate, alanine, and citrulline release into the portal vein were significantly decreased following treatment. The decrease in fasting systemic levels of glutamine requires more investigation. Peripheral muscle catabolism results not in the constituting amino acids but mainly in glutamine and alanine. Therefore the question arises whether lactulose and neomycin exert their ammonia lowering properties by nonbacterial mechanisms. An effect of diminished absorption of potential ammonia liberating amino acids can not be ruled out. A systemic effect of lactulose and neomycin on glutamine levels, and therefore on non-bacterial intestinal ammonia production is suggested. Further studies are needed to elucidate the mechanisms underlying these observations. 
control lactulose neomycin

$\begin{array}{lrcl}\text { ammonia (port) } & 61.5 \pm 9.3 & 49.5 \pm 9.9^{*} & 40.5 \pm 8.1^{*} \\ \text { ammonia (small) } & 45.4 \pm 6.4 & 30.6 \pm 6.1^{*} & 36.4 \pm 7.3 \\ \text { gln (port) } & -14.2 \pm 4.2 & -7.3 \pm 2.2^{*} & -2.6 \pm 0.8^{*} \\ \text { glu (port) } & 0.4 \pm 0.1 & 0.2 \pm 0.1 & -2.9 \pm 1.5 \\ \text { ala (port) } & 7.6 \pm 10.4 & 27.2 \pm 6.0^{*} & 25.7 \pm 5.7^{*} \\ \alpha \text {-amino- } & & & \\ \text { nitrogen (port) } & 159.1 \pm 39.8 & 100.1 \pm 28.8 & 84.8 \pm 29.5\end{array}$

Table 2. Total intestinal (port) and small bowel (small) production $(+)$ or utilization $(-)$ of ammonia, glutamine, glutamate, alanine, and total a-amino-nitrogen (as derived from portal minus arterial or superior mesenteric vein minus arterial concentrations times flow) for the six hours observation period pre and post standard meals ingestion, with and without lactulose (Legendal; $2 \times 60$ g/day during 7 days) or neomycin (8g/day during 7 days) treatment in six femalle piglets ( $20 \pm 0.8$ $\mathrm{kg}$ ). Results are expressed in mmol/6 hr (mean \pm sem).

- $=\mathrm{p}<0.05$ as compared to controls. 


\section{APPENDIX 1.}

ARTERLAL, PORTAL, AND HEPATIC AMINO ACID, AMMONIA, UREA, AND LACTATE LEVELS DURING PROLONGED FASTING.

\section{A.1.1. Introduction.}

Plasma concentrations of individual amino acids show diurnal rhythms (Wurtman 1968; Rapoport 1966; Squibb 1966; Purser 1966; Elwyn 1966, 1968, 1972; Rerat 1976). Therefore we undertook a separate study using our model to evaluate the fluctuations of amino acid, urea, ammonia, and lactate concentrations during prolonged fasting.

\section{A.1.2. Material and methods.}

Animals and surgical procedures.

Female crossbred (YorkshirexDutch Landrace) piglets of about $20 \pm 0.8 \mathrm{~kg}$ (mean $\pm \mathrm{sem} ; \mathrm{n}=6$ ) were used. Treatment before and after surgery and procedures to insert the catheters into the aorta, portal vein, and hepatic vein were similar as described in chapter 3.2.3.2.

\section{Experiments.}

Experiments were started after a recovery of at least three days. Pigs were fasted for 16 hours. During prolonged fasting blood was sampled for the determination of ammonia, urea, lactate and amino acids on $t=0,1,2,3,4,6$, and 8 hours.

Analyses.

Blood samples were immediately put on ice and transferred to the laboratory. After hematocrit determination the heparinized blood was centrifuged for ten minutes at four degrees centigrade. Plasma was frozen to $-70^{\circ} \mathrm{C}$ until determination of ammonia, urea, lactate and aminograms. Ammonia was determined with an automated (Cobas-Bio, Roche ${ }^{\mathrm{P}}$ ) enzymatic method (Sigma ammonia Kit) according to DaFonseca Wollheim (DaFonseca Wollheim 1974; Janssen 1987, 1988). Urea was determined with an automated (Cobas-Bio, Roche ${ }^{\text {T) }}$ ) enzymatic method (Bio Merieux Testkits) according to Hallett (1971) and Gutman (1974). Amino acids were determined with a HPLC employing ophthaldialdehyde precolumn derivatization (Andrews 1987; Godel 1984; Van Eijk 1988). Lactate was determined according to the method of Noll (1974) on a centrifugal analyzer (Cobas-Bio, Roche ${ }^{\mathbb{A}}$ ) using Boehringer testkits (149993). 


\section{A.1.3. Results}

The results are presented in tables A.1.a, A.1.b, and A.1.c. For the eight hour period of prolonged starvation there were no significant differences in urea, lactate, ammonia, and amino acid levels for the arteriall, portal and hepatic blood plasma levels.

\begin{tabular}{|c|c|c|c|c|c|c|c|}
\hline & 0 & 1 & 2 & 3 & 4 & $\ddot{6}$ & 8 \\
\hline glutam te & $173+42$ & $175 \div 40$ & $180+38$ & $166 \pm 33$ & $172 \pm 36$ & $151 \pm 38$ & $156+36$ \\
\hline a sparagine & $33 \pm 2$ & $32 \pm$ & $32 \pm 2$ & $33 \pm$ & $33 \pm 2$ & $40 \pm 7$ & $34 \pm 3$ \\
\hline serine & 1. $53 \pm 22$ & $144 \pm 19$ & $140 \pm 10$ & $143 \pm 19$ & $145 \pm 16$ & 150 世 77 & $147 \pm 19$ \\
\hline glutamine & $294 \pm 23$ & 282 专 18 & $298 \pm 26$ & $287 \pm 17$ & $285 \pm 19$ & $299 \pm 21$ & $310 \pm 21$ \\
\hline glycine & $528 \pm 98$ & $500 \pm 101$ & $498 \pm 89$ & $510 \pm 100$ & $490 \pm 86$ & $482+86$ & $490+89$ \\
\hline the onine & $87 \pm 11$ & $81 \pm 12$ & $84+10$ & $88 \pm 13$ & $90 \pm 1$ & $96 \pm 8$ & $93+11$ \\
\hline histidine & $51 \pm 5$ & $51 \pm 3$ & $52 \pm 3$ & $48 \pm \quad 4$ & $51 \pm 3$ & $56 \pm 4$ & $51 \pm 3$ \\
\hline cltrulline & $47 \pm 7$ & $48 \pm 6$ & $47 \pm 10$ & $46 \pm 7$ & $46 \pm 8$ & $48 \# 6$ & $44 \pm 6$ \\
\hline allandine & $198 \pm 25$ & $190 \pm 34$ & $185 \pm 30$ & $166 \pm 20$ & $211 \pm 52$ & $177 \pm 23$ & $176+32$ \\
\hline taurine & $74 \pm 6$ & $72 \pm \quad 5$ & $59 \pm 6$ & $59 \pm 5$ & $66 \pm 9$ & $73 \pm 5$ & $73 \pm 13$ \\
\hline arginine & $77 \pm 14$ & $76 \pm 12$ & $91 \pm 19$ & $76 \pm 11$ & $83 \pm 7$ & $91 \pm 6$ & $83+10$ \\
\hline tyrosine & $39 \pm 3$ & $34 \pm \quad 4$ & $37 \pm 5$ & $37 \pm 3$ & $39 \pm 4$ & $45 \pm 5$ & $38 \pm 4$ \\
\hline valine & $284+25$ & $264 \pm 28$ & $255 \pm 27$ & $262 \pm 25$ & $267 \pm 24$ & $267 \pm 22$ & $273+25$ \\
\hline methionine & $20 \pm 4$ & $17 \pm 3$ & $17 \pm 4$ & $18 \pm$ & $19 \pm 3$ & $23 \pm 4$ & $20 \pm 3$ \\
\hline isoleucine & $163 \pm 12$ & $147 \pm 11$ & $138 \pm 13$ & $143 \pm$ & $145 \pm 17$ & $147 \pm 17$ & $151 \pm 18$ \\
\hline phenyla lanine & $89 \pm 6$ & $86 \pm 7$ & $89 \pm 4$ & $95 \pm 8$ & $96 \# 7$ & $98 \pm 8$ & $55 \pm 6$ \\
\hline leucine & $276+19$ & $159 \pm 18$ & $150 \pm 14$ & $166 \pm 13$ & $169+17$ & $172 \pm 16$ & $173+26$ \\
\hline ornithine & $53 \pm 6$ & $49 \pm 5$ & $44 \pm 3$ & $54 \pm$ & 56 些 4 & $59 \pm 5$ & $54 \pm 5$ \\
\hline Iysine & $150 \pm 14$ & $135 \pm 13$ & $137 \pm 17$ & $142 \pm$ & 143 in 11 & $147 \pm 11$ & $146 \pm 15$ \\
\hline ammonia & $62 \pm 10$ & $51 \pm 8$ & $47 \pm 10$ & $42 \pm 9$ & $70 \pm 7$ & $46 \pm 9$ & $42 \pm 6$ \\
\hline urea & $3.3 \pm 0.5$ & $3.3 \pm 0.5$ & $3.3+0.5$ & $3.4 \pm 0.5$ & $3.4 \pm 0.5$ & $3.2 \pm 0.5$ & $3.3+0.5$ \\
\hline lactate & $1.3 \pm 0.4$ & $0.9 \pm 0.2$ & $0.8 \pm 0.1$ & $0.7 \pm 0.1$ & $1.0 \pm 0.3$ & $0.8 \pm 0.6$ & $0.8 \pm 0.0$ \\
\hline
\end{tabular}

Tabel A.1.a. Arteriall amino acid, ammonia ${ }_{i n}$ urea $_{3}$ and lactate levels $\left(\mu \mathrm{mol} / \mathrm{L}_{\mathrm{c}}\right.$ mean $\pm \mathrm{sem} ; \mathrm{m}=6 \mathrm{a}$ nimals) during prolonged fasting. 


\begin{tabular}{|c|c|c|c|c|c|c|c|c|c|c|c|c|}
\hline & 0 & 1 & & 2 & & 3 & & 4 & & 6 & 8 & \\
\hline gl ut & $161 \pm 43$ & $165 \pm$ & 40 & 1.6.4 & 35 & $156 t$ & 33 & $166 \pm$ & 34 & $151 \pm 37$ & 1331 & 34 \\
\hline aparage & $3 \pm 2$ & $32 \pm$ & 3 & $42 \pm$ & 5 & $34=$ & 2 & 34 & 2 & $40 \pm$ & $42 \pm$ & 5 \\
\hline the & $147 \pm 23$ & $242 \pm$ & 50 & $150 \pm$ & 22 & $136 \pm$ & 17 & $132 \pm$ & 16 & $148+18$ & $143 t$ & 56 \\
\hline glutam ine & $256 \pm 19$ & $238 \pm$ & 11 & 247 息 & 15 & $245=$ & 12 & 244 & 10 & $80 \pm 14$ & $277 \pm$ & 22 \\
\hline glyeine & $545 \pm 105$ & $513 \pm$ & 100 & $512 \pm 1$ & 02 & $510 \pm 1$ & 100 & $489 \pm$ & 86 & $510 \pm 69$ & $489 \pm$ & 95 \\
\hline threntrie & $82 \pm 22$ & $76 \pm$ & 11 & $90 \pm$ & 11 & 84 & 9 & $3 \pm$ & 7 & $94 \pm$ & $91 \pm$ & 7 \\
\hline histidine & $53 \pm 4$ & $51 \pm$ & 3 & $55 \pm$ & 4 & $48 \pm$ & 4 & 504 & 3 & $55 \pm$ & $56 \pm$ & 4 \\
\hline citrulline & $55 \pm 10$ & $53:$ & 9 & $60 \pm$ & 8 & $54 \pm$ & 9 & $54 \pm$ & 10 & $52 \pm 8$ & $52 \pm$ & 5 \\
\hline Alanine & $162 \pm 23$ & $201 \pm$ & 25 & $205 \pm$ & 29 & $178 \pm$ & 26 & $213 \pm$ & 52 & $190 \pm 65$ & $178 \pm$ & 26 \\
\hline tatrine & $81 \pm 8$ & $67 \pm$ & 3 & $60 \pm$ & 8 & $60 \pm$ & 5 & $63 \pm$ & 9 & $68 \pm$ & 66. & 11 \\
\hline arginine & $87 \pm 14$ & $76 \pm$ & 12 & 89 & 14 & 81 & 14 & $83 \pm$ & 7 & $92 \pm$ & $90 \pm$ & 8 \\
\hline tyrosine & $38 \pm 2$ & $34 \pm$ & 3 & 45 & 4 & 35 & 3 & $35+$ & 1 & $38 \pm$ & $40 \pm$ & 5 \\
\hline vol Line & $278 \pm 23$ & $261 \pm$ & 24 & $267 \pm$ & 23 & 2594 & 19 & $264 \pm$ & 22 & $277 \pm 24$ & $26.3 \pm$ & 19 \\
\hline methioning & $20 \pm 4$ & 161 & 3 & $23 \pm$ & 3 & $19 \pm$ & 2 & $19 \pm$ & 2 & $19 \pm$ & $24 \pm$ & 3 \\
\hline i. & $158 \pm 8$ & $146 \pm$ & 10 & $148 \pm$ & 8 & $142 t$ & 9 & $142 \pm$ & 16 & $154 \pm 17$ & $146 \pm$ & 14 \\
\hline phenylan landne & $90 \pm 3$ & B5 & $\Phi$ & $101 \pm$ & 8 & $95 \pm$ & 6 & $96 \pm$ & $B$ & $103 \pm 9$ & $96 \pm$ & 6 \\
\hline leuctine & $178 \pm 12$ & $161 \pm$ & 15 & $172 \pm$ & 12 & $162 \pm$ & 10 & $168 \pm$ & 17 & $181 \pm 17$ & $171 \pm$ & 12 \\
\hline ornithine & $53 \pm 4$ & $49 t$ & 4 & $53 \pm$ & 4 & $50 \pm$ & 6 & $50 \pm$ & 5. & $59 \pm 5$ & $55 \pm$ & 6 \\
\hline 1ysine & $152+25$ & $138 \pm$ & 12 & $150 \pm$ & 16 & $150 \pm$ & $B$ & $146 \pm$ & 8 & $157 \pm 11$ & 1514 & 19 \\
\hline 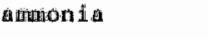 & $237 \pm 57$ & $184 \pm$ & 30 & $223 \pm$ & 53 & $212 \pm$ & 47 & $227 \pm$ & 53 & $173 \pm 84$ & $139 \pm$ & 15 \\
\hline we a & $3.3 \pm 0.6$ & $3.3 \pm 0$ & & $3,4 \pm 0$ & 0.6 & $3.5+0$ & & $3 \cdot 5 \pm 0$ & 0.5 & $3.3 \pm 0.6$ & $3.4 \pm 0$ & .6 \\
\hline lactate & $1.3+0.3$ & $0.9 \pm 0$ & & $0.9 \pm 0$ & .2 & 0.80 & & 1. $0 \pm 0$ & U. 3 & $0.8+0.1$ & $0.8 \pm 0$ & \\
\hline
\end{tabular}

Table A.1.b. Portal amino acid, ammonia, urea, and lactate levels $(\mu \mathrm{mol} / \mathrm{L} ;$ mean $\pm \mathrm{sem} ; \mathrm{n}=6$ animals) during prolonged fasting.

\begin{tabular}{|c|c|c|c|c|c|c|c|c|c|c|}
\hline & 0 & 1 & & 2 & & 3 & & 4 & 6 & 8 \\
\hline glutamate & $15 B \pm 40$ & $165 \pm$ & 37 & $157 \pm$ & 34 & $246 \pm$ & 33 & $140 \pm 33$ & $139 \pm 33$ & $133 \pm 38$ \\
\hline asparagina & $35 \pm 2$ & $33 t$ & 5 & $35 \pm$ & 3 & $40 \pm$ & 5 & $34 \pm$ & $41 \pm$ & $39 \pm$ \\
\hline serine & $150 \pm 23$ & $148 \pm$ & 26 & $140 \pm$ & 20 & $146 \pm$ & 19 & $146 \pm 20$ & $150 \pm 19$ & $140 \div 19$ \\
\hline glutamine & $265 \pm 30$ & $264 \pm$ & 27 & $268 \pm$ & 24 & $287 \pm$ & 32 & $262 \pm 26$ & $297 \pm 29$ & $299 \pm 30$ \\
\hline glycine & $519 \pm 131$ & $495 \pm$ & 127 & $481 \pm 1$ & 14 & $497 \pm=$ & 126 & $467 \pm 106$ & $488 \pm 105$ & $476 \pm 104$ \\
\hline threonine & $87 \pm 13$ & $85 \pm$ & 17 & $89 \pm$ & 16 & $97 \pm$ & 14 & $90 \pm 13$ & $101 \pm 14$ & $97 \pm 15$ \\
\hline hilitidine & $50 \pm 4$ & $52 \pm$ & 6 & $48 \pm$ & 5 & $56 \pm$ & 5 & $49 \pm$ & $53 \pm$ & $55 \pm$ \\
\hline cicruldine & $44 \pm \quad 9$ & $42 \pm$ & 8 & $44 \pm$ & 7 & 461 & 7 & $40 \pm$ & $43 \pm$ & $52 \pm$ \\
\hline L L I nure & $184 \pm 23$ & $175 \pm$ & 16 & $168 \pm$ & 20 & $163 \pm$ & 22 & $197 \pm 70$ & $176 \pm 32$ & $162 \pm 27$ \\
\hline taur ine & $77 \pm 6$ & $70 \pm$ & 4 & $60 \pm$ & 6 & $63 \pm$ & 6 & $61 \pm$ & $74 \pm 8$ & $70 \pm 13$ \\
\hline arglnine & $80 \pm 16$ & 771 & 15 & $74 \pm$ & 13 & 94 㪴 & 9 & $79 \pm$ & $88+11$ & $89 \pm 11$ \\
\hline tyrosine & $30 \pm 4$ & $36 \pm$ & 5 & 39. & 4 & $43 \pm$ & 3 & $36 \pm$ & $39 \pm 4$ & $39 \pm$ \\
\hline viane & $83 \pm 31$ & $277 \pm$ & 35 & $268 \pm$ & 30 & $276 \pm$ & 29 & $268 \pm 29$ & $292 \pm 32$ & $282 \pm 31$ \\
\hline mothionlne & $19 \pm 5$ & $17 \pm$ & 4 & $20 \pm$ & 3 & 221 & 4 & $17 \pm$ & $21 \pm$ & $22 \pm$ \\
\hline 1solencine & $160 \pm 212$ & $150 \pm$ & 15 & $143 \pm$ & 11 & 1461 & 14 & $144 \pm 19$ & $161 \pm 23$ & $157 \pm 22$ \\
\hline pheny la lianine & $90 \pm 5$ & 891 & 9 & $200 \pm$ & 9 & 1011 & 7 & $98 \pm 7$ & $107 \pm 9$ & $103 \pm$ \\
\hline leucl ine & $180 \pm \mathbb{1 1 9}$ & $167 \pm$ & 22 & $160 \pm$ & 15 & $17: 1$ & 18 & $168 \pm 20$ & $184 \pm 23$ & $179 \pm 22$ \\
\hline Ornithine & $59 \pm 7$ & $54 \pm$ & 6 & $60 \pm$ & 4 & $60 \pm$ & 3 & $62 \pm \quad 3$ & $62 \pm$ & $63 \pm$ \\
\hline lysine & $147 \pm 16$ & 1371 & 17 & $140 \pm$ & 13 & $142 \pm$ & 18 & $141 \pm 14$ & $153 \pm 15$ & $153 \pm 20$ \\
\hline A monon ia & $64 \pm 7$ & $64 t$ & B & $64 \pm$ & 10 & 541 & 11 & $49 \pm 7$ & $57 \pm 9$ & $52 \pm$ \\
\hline urent & $3.3 \pm 0.7$ & $3.3 \pm 0$ & & $3.3+0$ & .6 & $3.4 \pm 0$ & .6 & $3.4 \pm 0.5$ & $3.4 \pm 0.6$ & $3.4 \pm 0.6$ \\
\hline lact te & $1.3 \pm 0.4$ & 0.910 & & $0.8 \pm 0$ & .1 & $0.6 \pm 0$ & 1 & $1.1 \pm 0.4$ & $0.9 \pm 0.2$ & $0.8+0.1$ \\
\hline
\end{tabular}

Table A.1.c. Hepatic amino acid, ammonia, urea, and lactate levels ( $\mu$ mol/L; mean $\pm \mathrm{sem} ; n=6$ animuls) during prolonged fasting. 


\section{A.1.4. Comments.}

Munro (1970) distinguished three groups of factors affecting free amino acid pools:

a. diet: the amount of protein, fat, carbohydrates, vitamins, and minerals which affect the fate of absorbed amino acids.

b. hormones influencing:

-rate of transfer between extracellular and intracellular pools.

-rate of utilization for protein synthesis, transamination and other means of disposal.

-rate of degradation of protein with release of amino acids into the intracellular pool.

-rate of synthesis of the amino acid from precursors if it is a nonessential one.

c. miscellaneous

-physiological: sex, age, stress, biological rhythms.

-pathological: liver disease, diabetes, sepsis, trauma.

It was not our purpose to deal with all these influences in detail. The only aim of this study was to certify that the effects described in chapters 3 and 4 were not just due to a normal diurnal rhythm. Therefore we followed amino acid, lactate, urea, and ammonia concentrations during prolonged starvation. The results show no significant differences in amino acid, lactate, urea, and ammonia levels during the eight hour study period. We conclude that the effects measured and described in chapters 3 and 4 can be considered treatment (diet, lactulose, neomycin) dependent. 


\section{APPENDIX 2.}

AMINO ACID LEVELS IN PLASMA AND WHOLE BLOOD: PRELIMINARY RESULTS.

\section{A.2.1. Introduction.}

While studying amino acid metabolism some authors refer to plasma concentrations of various amino acids (Souba 1983, 1984, 1985; Bark 1980) while others use whole blood levels (Rerat 1976, 1985; Heberer 1985). Elwyn (1966, 1968, 1972) showed differences in plasma and erythrocyte amino acid levels in a dog model. The aim of this study was to investigate possible differences between plasma and whole blood free amino acid levels in our pig model.

\section{A.2.2. Material and methods.}

Animals and surgical procedures.

A female crossbred (YorkshirexDutch Landrace) piglet of $22 \mathrm{~kg}$ was used. Treatment before and after surgery and procedures to insert the catheters into the aorta and portal vein were similar as described in chapter 3.2.3.2.

Experiments.

Experiments were started after a recovery of at least three days. Blood was sampled for the determination of amino acids after a starvation period of 16 hours on seven different days.

Analyses.

Blood samples were immediately put on ice and transferred to the laboratory. After hematocrit determination a whole blood sample was taken. The rest of the heparinized blood was centrifuged for ten minutes at four degrees centigrade. Plasma and whole blood were frozen to $-70^{\circ} \mathrm{C}$ until determination of aminograms. Amino acids were determined with an automated HPLC employing ophthaldialdehyde precolumn derivatization (Andrews 1987; Godel 1984; Van Eijk 1988).

\section{A.2.3. Results:}

Results are presented in table A.2. Significant differences were found between plasma and whole blood for glutamate (P: $118 \pm 8$ vs $302 \pm 5 ; A: 133 \pm 8$ vs $319 \pm 9 \mu \mathrm{mol} / \mathrm{L}$ ), glycine (P: $643 \pm 6$ vs $918 \pm 18 ; A: 626 \pm 7$ vs $956 \pm 43 \mu \mathrm{mol} / \mathrm{L}$ ), threonine (P: $81 \pm 4$ vs $98 \pm 3$; A: $77 \pm 2$ vs $101 \pm 3 \mu \mathrm{mol} / \mathrm{L}$ ), histidine (P: $61 \pm 1$ vs $61 \pm 4$; A: $57 \pm 1$ ws $62 \pm 6 \mu \mathrm{mol} / \mathrm{L}$ ), citrulline (P: $52 \pm 1$ vs $58 \pm 1$; A: $41 \pm 1$ 
vs $52 \pm 4 \mu \mathrm{mol} / \mathrm{L}$ ), taurine (P: $50 \pm 2$ vs $346 \pm 5$; A: $56 \pm 4$ vs $366 \pm 13 \mu \mathrm{mol} / \mathrm{L}$ ), arginine (P: $103 \pm 3$ vs $65 \pm 2 ; A: 96 \pm 2$ vs $66 \pm 2 \mu \mathrm{mol} / \mathrm{L}$ ), tyrosine (P: $38 \pm 4$ vs $52 \pm 2$; A: $36 \pm 3$ vs $53 \pm 1 \mu \mathrm{mol} / \mathrm{L}$ ), isoleucine (P: $144 \pm 4$ vs $150 \pm 7$; A: $139 \pm 3$ vs $161 \pm 5 \mu \mathrm{mol} / \mathrm{L}$ ), ornithine (P: $44 \pm 2$ vs $77 \pm 4$; A: $39 \pm 2$ vs $83 \pm 3 \mu \mathrm{mol} / \mathrm{L}$ ), and lysine (P: $174 \pm 6$ vs $215 \pm 5$; A: $161 \pm 5$ vs $216 \pm 9 \mu \mathrm{mol} / \mathrm{L}$ ), in arterial (A) as well as in portal (P) blood.

\section{A.2.4. Comments.}

Elwyn $(1966,1968,1972)$ studied the 24 hour distribution of amino acids between plasma and red blood cells in the "normal" dog in vitro and in vivo. Time-weighted means of the distribution ratios (concentration in erythrocytes/ concentration in plasma) showed differences between various amino acids and various vessels. Concentrations of amino acids in red blood cells might be expected to reach with time a steady state equilibrium with plasma. The rate of change would be determined by kinetic factors (tissue exchange, flow, nutritionall state, time). Winter and Christensen (1964) indicated several minutes to hours to reach isotopic equilibrium in in vitro studies with human erythrocytes. This would mean that the more time blood remains between various organs (as in large vessels) the more the in vitro equilibrium will be approached. Rapidly exchanging amino acids (leucine, isoleucine, valine) showed a smaller diversibility in free amino acid distribution between vessels than more polar amino acids which exchange slower (glycine) (Winter 1964). Plasma will reflect changes more rapidly than red blood cells. This is especially relevant after feeding. Therefore we decided to start our comparisons in the fasted state. To eliminate possible artifacts induced by the sampling procedure samples were treated instantly and simultaneously after collection. After 16 hours of starvation we observed differences in the distribution of amino acids between plasma and whole blood. These could indeed be related to the polarity of the amino acids. The significant differences occurred in the polar amino acids. We studied only one animal after seven periods of an overnight fast. Intra-individual variation turned out to be small. Although we expect that variations of most amino acids will be faster expressed in plasma than in whole blood, further studies are needed to get insight in the distribution of free amino acids in erythrocyte and plasma during several physiological and pathophysiological states. Inter-individual differences and the role of feeding require a separate approach. Using a modern automated HPLC technique ( 45 minutes per run compared to the 24 hours in Elwyn's study) these questions can be handled in a point by point manner. For the moment it appears that the use of plasma amino acid levels, not dealing with difficult distribution problems caused by transport across membranes, kinetics, and $\mathrm{pH}$, should be preferred in metabolic studies. 
Portal

plasma whole blood
Arterial

$$
\text { plasma }
$$

wholle blood

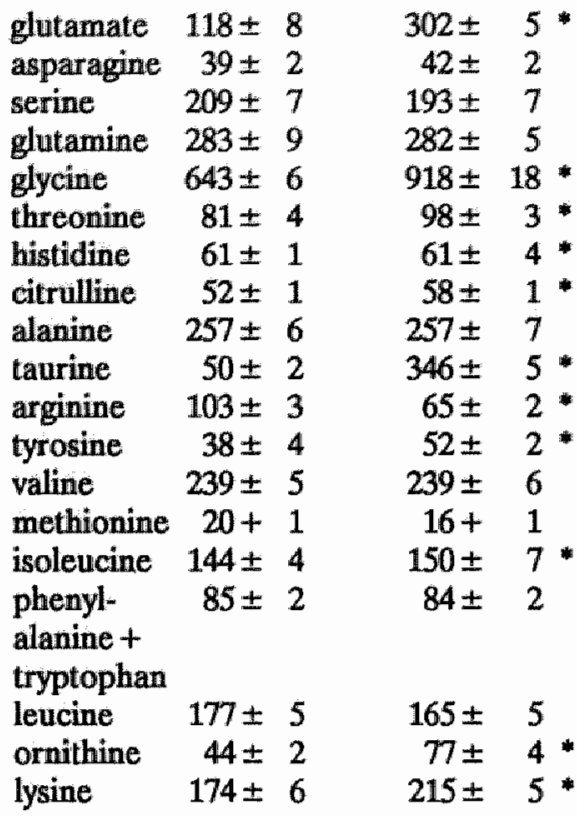

$\begin{array}{rrrr}133 \pm 8 & 319 \pm & 9 * \\ 32 \pm 1 & 39 \pm & 1 \\ 203 \pm 5 & 204 \pm & 9 \\ 332 \pm 7 & 338 \pm & 13 \\ 626 \pm 7 & 956 \pm & 43 * \\ 77 \pm 2 & 101 \pm & 3 \\ 57 \pm 1 & 62 \pm & 6 \\ 41 \pm 1 & 52 \pm & 4 \\ 232 \pm 7 & 257 \pm & 10 \\ 56 \pm 4 & 366 \pm & 13 * \\ 96 \pm 2 & 66 \pm & 2 \\ 36 \pm 3 & 53 \pm & 1 \\ 232 \pm 4 & 251 \pm & 9 \\ 18+1 & 17 \pm & 1 \\ 139 \pm 3 & 161 \pm & 5 * \\ 79 \pm 1 & 85 \pm & 3\end{array}$

$157 \pm 5$

$171 \pm 6$

$39 \pm 2$

$83 \pm 3$ *

$161 \pm 5$

* $p<0.05$ as compared to plasma.

Table A.2. Comparison of plasma and whole blood amino acids ( $\mu$ mol/L;mean $\pm \operatorname{sem} ; n=7$ deter minations). 


\section{SUMMARY}

This thesis contains three major sections. The first section (chapter 1) is a literature review explaining the background of the thesis. In the second section (chapter 2) the animal model, laboratory techniques and measurements used are described. The third section (chapters 3 and 4) contains a description of the actual experiments underlying this thesis.

In an appendix baseline values of amino acid, ammonia, urea, and lactate levels are given.

In chapter 1 a brief review is given of the literature concerning the leading role that ammonia still plays in the postulated pathogenesis of hepatic encephalopathy. Ammonia production and therapies decreasing systemic ammonia levels have always been associated with bacterial mechanisms. Non-bacterial glutamine dependent intestinal ammonia production is reviewed. The gut is viewed as an organ of digestion and absorption, but also as an important regulator in protein metabolism. Interorgan relationships between gut and other tissues (liver, kidney, peripheral muscle) are discussed. The differences in toxicity and ammonia rendering potential of various proteins in liver insufficiency are highlighted. Bacterial and non-bacterial modes of action of neomycin and lactulose in the therapy of hepatic encephalopathy are discussed.

In chapter 2 the use of the pig as an appropriate animal model because of its gastro-intestinal similarity to man is explained. A technique developed in our laboratory to allow unrestrained repeated blood sampling of portal and arterial blood and selectively of small and large bowel veins is described. Electromagnetic flow measurements are used as a means to follow the dynamics of metabolism. For the determination of amino acids we used in addition to a conventional amino acid analyzer (LKB) a fully automated determination of amino acids by a high performance liquid chromatography. The determination of plasma and whole blood ammonia is evaluated in chapter 2.4 .

In chapter 3.1. investigations of the role of protein in increasing ammonia liberation are described. In the hierarchy of toxicity of protein during liver insufficiency blood is known to give rise to the highest ammonia levels as compared to isonitrogenous amounts of vegetable, dairy, and meat protein. The importance of this observation resides in the fact that hepatic encephalopathy often occurs after intestinal bleeding. Therefore we studied ammonia, urea, and amino acid levels repeatedly after blood meals in healthy piglets and compared these to normal pigmeals. In a second series of experiments the same procedure was performed after ingestion of an isonitrogenous amount of bovine whole blood, plasma, erythrocytes, and pigfood. Electromagnetic flowmeasurements enabled us to calculate net production or utilization across the bowel. After a blood meal portal ammonia release was increased twofold. Increased glutamine utilization as hypothesized previously could not be detected. Isoleucine levels decreased to $25 \%$ of fasting levels. Analysis of blood constituents revealed a 
complete lack of isoleucine in the hemoglobin molecule. Net total $\alpha$-amino-nitrogen absorption was doubled after a blood meal. These findings lead us to hypothesize that due to complete lack of isoleucine in hemoglobin ingestion of blood into the gut presents the organism with protein of low biological value, leading to decreased protein synthesis and to net protein degradation, which in turn may result in increased ammonia and urea production.

To shed further light on this hypothesis the experiments described in chapter 3.2 were performed. Ingestion of erythrocytes was compared with isonitrogenous amounts of isoleucine enriched erythrocytes. Intestinal but also liver metabolism of amino acids, ammonia, lactate, and urea were calculated. The enrichment of erythrocytes with an excess of isoleucine diminished ammoniagenesis and ureagenesis, but not significantly. Less lactate was metabolized after the isoleucine enriched erythrocyte meal. After enrichment less glutamine was produced in the liver. Less alanine was consumed, indicating that less protein constituents were used in gluconeogenic pathways. These data furnish some support for the hypothesis that the toxicity of blood protein is just the consequence of its biological value. These experiments need to be repeated with smaller amounts of isoleucine because we administered an excess of isoleucine compared to the daily requirements of pigs.

In chapter 4 the hypothesis that lactulose and neomycin might act on glutamine dependent ammonia production is evaluated. Ammonia, amino acids and urea levels were measured in arterial and portal blood of catheterized piglets, pretreated with lactulose or neomycin, before, and after ingestion of normal pigfood and compared with control periods in the same animals. Portal and porta-arterial ammonia differences were significantly decreased after lactulose and neomycin treatment. Alpha-amino-nitrogen absorption decreased in both treatment groups compared to controls, but this decrease did not reach significance. Systemic and portal glutamine levels as well as intestinal glutamine utilization were significantly lower in the treatment groups. Citrulline and glutamate levels and intestinal production decreased after treatment. The decreased systemic and consequently intestinal glutamine utilization may contribute to a reduction of endogenous ammonia formation in the gut wall. An effect of diminished absorption of $\alpha$-amino-nitrogen can not be ruled out. These results are in accordance with earlier observations in vivo and in vitro in Wistar rats.

In appendix 1 amino acid, lactate, urea, and ammonia concentrations showed no significant differences during prolonged fasting. Therefore the effects measured in chapters 3 and 4 can be considered to be the result of treatment.

In appendix 2 differences between plasma and whole blood free amino acid levels in the pig model are described and related to differences in the polarity of the amino acids. The preference of plasma amino acid levels in metabolic studies, not dealing with difficult distribution problems, is discussed. 


\section{SAMENVATTING}

Dit proefschrift is opgebouwd uit drie delen. Het eerste gedeelte (hoofdstuk 1) geeft een overzicht van de literatuur als achtergrond voar de proeven. In het tweede gedeelte (hoofdstuk 2) worden het proefdiermodel, de laboratorium technieken en meetmethoden beschreven. Het derde deel (hoofdstukken 3 en 4) bevat een beschrijving van de eigenlijke studies die ten grondslag liggen aan dit proefschrift. In twee appendices worden uitgangswaarden van aminozuren, ammoniak, ureum, en lactaat weergegeven.

In hoofdstuk 1 wordt een korte samenvatting gegeven van de literatuur met betrekking tot de nog steeds belangrijke rol die ammoniak wordt toebedeeld in hypothesen die het ontstaan van hepatische encephalopathie trachten te verklaren. Ammoniak produktie is altijd in verband gebracht met bacterielle mechanismen, en therapieën die systemische ammoniakspiegels doen dalen hebben zich bijgevolg steeds geconcentreerd op deze mechanismen. In dit hoofdstuk wordt ook de niet-bacteriële, glutamine afhankelijke, intestinale ammoniak produktie besproken. De darm wordt belicht als een orgaan waar vertering en absorptie plaatsvinden, maar ook als een belangrijke regulator van eiwit metabolisme. Metabole relaties tussen de darm enerzijds, en lever, nier en spierweefsel anderzijds worden verklaard. De tolerantie voor verschillende eiwitten en de mate waarin deze eiwitten bijdragen tot ammoniak vorming worden belicht in relatie tot de ernst van de leverinsufficientie. Potentiële bacteriële en niet-bacteriële werkingswijzen van neomycinesulfaat en lactulose, als therapeutica bij hepatische encephalopathie, worden besproken.

In hoofdstuk 2 wordt beschreven dat het jonge varken wordt gekozen als proefdier omdat ruime overeenkomst in morfollogie en fysiologie bestaat met de tractus digestivus van de mens. Een in ons laboratorium ontwikkelde techniek voor het stressvrij afnemen van portaal, arterieel, en selectief veneus dun- en dikdarm bloed wordt beschreven. Electromagnetische flowmetingen werden gebruikt om de dynamiek van het metabolisme te volgen. Voor de analyse van aminozuren werd naast de conventionele aminozuuranalysator (LKB) een volledig geautomatiseerde HPLC-techniek, gebaseerd op de ophthaldialdehyde (OPA) derivatiserings reaktie gebruikt. De bepaling van plasma en volbloed ammoniak wordt in hoofstuk 2.4 belicht.

In hoofdstuk 3.1. werd de rol van eiwit in verhoogde ammoniak vorming onderzocht. Het blijkt dat bij leverinsufficientie uit bloed meer ammoniak vrijkomt dan uit isomitrogene hoeveelheden plantaardig, zuivel, of dierlijk eiwit. Het belang van deze observatie is gelegen in het feit dat hepatische encephalopathie dikwijls voorafgegaan wordt door maagdarmbloedingen. Daarom werden ammoniak, ureum en aminozuur spiegels gedurende enkele uren na bloedmaaltijden bestudeerd bij jonge, gezonde varkens. Deze waarden werden vergeleken met die verkregen na consumptie van gelijke hoeveelheden stikstof bevattende normale varkensmaaltijden. In een tweede serie experimenten werden dezelfde 
bepalingen gedaan na maaltijden bestaande uit isonitrogene hoeveelheden erythrocyten, plasma, volbloed en varkensvoer. Electromagnetische flowmetingen maakten berekening van netto produktie of verbruik over de darm mogelijk. Na cen bloedmaalitjd steeg de portale ammoniakproduktie met een factor twee. Verhoogd glutamineverbruik, zoals eerder gehypothetiseerd, kon niet worden aangetoond. Isoleucine spiegels daalden tot $25 \%$ van de waarden na vasten. Analyse van bloedprodukten bracht een geheel ontbreken wan isoleucine in het hemoglobine molecuul aan het licht. Netto totaal $\alpha$-aminio-stikstof absorptie was vertweevoudigd na een bloedmaaltijd. Deze bevindingen leidden tot de hypothese dat tengevolge van compleet afwezig zijn van isoleucine in hemoglobine, opname van bloed in de tractus digestivus het lichaam belast met eiwit van lage biologische waarde. Dit kan leiden tot verminderde eiwitsynthese en tot netto eiwitafbraak, ofwel tot verhoogde ammoniak- c.q. ureumproduktie.

Om deze hypothese verder uit te werken werden de experimenten beschreven in hoofdstuk 3.2. uitgevoerd. Het eten van erythrocyten werd vergeleken met evenveel stikstof bevattende hoeveelheden erythrocyten, die verrijkt waren met het ontbrekende isoleucine. Darm en lever metabolisme van aminozuren, ammoniak, lactaat, en ureum werden berekend. De verrijking van erythrocyten met een grote hoeveelheid isoleucine verminderde de ammoniak- en ureumvorming, alhoewel dit effect niet significant was. Er werd minder lactaat gemetaboliseerd na de met isoleucine verrijkte erythrocytenmaaltijd. Na de verrijking werd minder glutamine geproduceerd in de lever. Minder alanine werd verbruikt, hetgeen mogelijk betekent dat minder eiwit werd verbruikt in gluconeogene reakties. Deze data ondersteunen de hypothese dat de toxiciteit van bloedeiwit het gevolg is van de lage biologische waarde ervan. Deze experimenten moeten echter herhaald worden met kleinere hoeveelheden isoleucine, omdat veel meer isoleucine dan de dagelijkse behoefte van een jong varken werd gesuppleerd.

In hoofdstuk vier wordt de hypothese geèvalueerd dat lactulose en neomycinesulfaat hun effect sorteren middels de glutamine afhankelijke ammoniakproduktic. Ammoniak, aminozuren en ureumspiegels werden gemeten in arterieel en portaal bloed van gecatheteriseerde jonge varkens, die waren voorbehandeld met lactulose of neomycinesulfaat. De waarden voor, en na opname van standaard varkensvoer werden vergeleken met controle perioden in dezelfde proefdieren. Portale en porta-arteriele ammoniakverschillen waren significant lager na behandeling met lactulose en neomycinesulfaat. Alfa-amino-stikstof absorptie verminderde in beide therapiegroepen vergeleken met controles, maar dit verschil bereikte geen significantie. Systemische en portale glutamine spiegells en intestinale glutamine utilisatie waren significant lager in de behandelde groepen. Systemische citrulline en glutaminezuur spiegels en de intestinale produktie ervan verminderden na behandeling. De verlaagde systemische en de dientengevolge verlaagde intestinale glutamine utilisatie kunnen bijdragen tot een vermindering van endogene ammoniak produktie in de darmwand. Een effect van verminderde absorptie van $\alpha$-amino-stikstof kan niet worden uitgesloten. Deze resultaten zijn in overeenstemming met eerdere observaties in vivo en in vitro in Wistar ratten. 
In appendix 1 wordt aangetoond dat aminozuren, lactaat, ureum, en ammoniak concentraties niet significant veranderen gedurende langdurig vasten. Daarom kunnen de effecten gemeten in hoofdstukken 3 en 4 beschouwd worden als het resultaat van behandeling.

In appendix 2 worden verschillen tussen plasma- en volbloed- vrije- aminozuurspiegels in het varkensmodel gerelateerd aan verschillen in polariteit van de aminozuren. De bepaling van plasma aminozuurspiegels in metabole studies wordt vergeleken met de bepaling van volbloed aminozuurspiegels. 


\section{REFERENCES}

- Abecassis J Darvid-Eteve Ch, Soun A. J Liq Chromat, 198; 8: 135.

- Adibi SA, Gray SJ. Gastroenterology, 1967; 52: 837.

- Adibi SA. Gastroentenology, 1969; 56: 903.

- Adibi SA. J Appl Physiol, 1970; 28: 753.

- Agostini L, Down PP, Murison 1, Wrong OM. Gut, 1972; 13: 859.

- Alpers DH. J Clin Invest, 1972; 51: 167.

- Andrews RP. In: LKB protein chemistry notes (14). LKB Biochrom Ltd, 1987.

- Anken van HC, Schiphorst ME. Clin Chim Acta, 1974; 56: 151.

- Annison EF, Hill KJ, Lewis D. Biochem J, 1955; 60: 19.

- Annison EF, Hill KI, Lewis D. Biochem J, 1957; 66: 592.

- Antonini E. In: Front Biol, Neuberger B, Tatum E, eds, Amsterdam, North Holland, 1971; 21 : 62.

- Armstrong MD, Stave U. Metabolism, 1973; 22: 549.

- Ansac M, Rerat AA. Ann Biol Anim Biochem Biophys, 1962; 2: 335.

- Asatoor AM, Chamberlain MJ, Emmerson BE Clin Sci, 1967; 33: 111.

- Auffray P. Conference au comite Scientifique de Pathologie porcine, 1965.

- Auffray P, Martinet J, Rerat AA. Ann Biol Anim Biochem Biophys, 1967; 7: 261.

- Bathr KH, Schulze W. Z Rheumaforschg, 1972; 31: 99.

- Baraldi M, Massotti M, Zeneroli ML, Vezzelli C. In: Soeters PB, Wilson JHP, Meijer AJ, Holm E, eds. Advances in Ammonia Metabiolism and Hepatic Encephalopathy, 1988: 238.

- Barcroft J, McAnnally RA, Phillipson AT, J Exp Biol,1944; 20: 120.

- Bark S. Acta Chir Scand Suppl, 1980; 497.

- Bender DA. John Wiley and Sons, New York, 1985.

- Benevenga NJ. Swine in Biomedical Research, 1986; 2: 1017.

- Bennett A, Eley KG. J Pharm Pharmacol, 1976; 28: 192.

- Berkson J, Gage RP. Proc Staff Meet, Mayo Clin, 1950; 25: 270.

- Berlo van CLH, Bogaard wan den AEJM, Kelderman PHMW, Dongen van JJ, Heijden van der M.A.H., Soeters PB. In: Soeters PB, Wilson JHP, Meijer AJ, Holm E, eds. Advances in Ammonia Metabolism and Hepatic Encephalopathy, 1988: 300.

- Berto vain CLF, Bogaard van den AEJM, Bost MCF, Soeters PB. Lab Anim Sci, 1988, in press.

- Berlo van CLH, Jonge de HR, Bogaard AEJM, Eijk HMH, Janssen MA, Soeters PB. Gastroenterology; 1987; 93: 472 .

- Berlo van CLH, Lceuwen van PAM, Soeters PB. J Hepatol, 1988, in press.

- Berlo van CLH, Bogaard van den AEJM, Heijden van der MAH, Ejjk wan HMH, Janssen MA, Bost MCF, Soeters PB. Advances in Ammonia Metabolism and Hepatic Encephalopathy 1988: $^{\circ}$ 154.

- Berto van CLH, Bogaard wan den AEJM, Heijden van der MAH, Bijk van HMH, Janssen MA, Bost MCF, Socters PB. Hepatology, 1988, in press.

- Bessman AN, Hawkins R. Gastroenterology, 1963; $45: 368$.

- Bcssman AN, Mirick GS, Hawkins R J Clin Invest, 1958; 37: 990.

- Bessman SP, Magnes J, Schwerin P, Waelsch H. J Biol Chem, 1948; 175: 817.

- Betner 1, Poldi P. Chromatographia, 1986; 22: 381.

- Bircher J, Muller J" Guggenheim P. Haemmuli UP. Lancet, 1966; 1: 890.

- Boganard van den AEJM, Weidema WF. JAVMA, 1985; 186: 990.

- Bown RL, Gibson JA, Sladen GE, Hicks B, Dawson AM. Gut, 1974; 15: 999. 
- Bronk JR, Parsons DS. J Physiol, 1966; 184: 950.

- Brown H, O'Hara E, Brown ME, Cowellif VH, Konda D McDermott Jr WV. JAMA, 1987; 199: 641.

- Bruijn de KM, Blendis LM, Zilm DH, Carten PL, Anderson GH, Gut, 1983; 24: 53.

- Brijin de KMM. Thesis, University of Groningen, Groningen, The Netherlands, 1986.

- Buraczewski S, Porter JWG, Rolls: BA, Zebrowska T. Br J Nutr, 1971; 25: 299.

- Bustad LK, McClellan RO. Swine in Biomedical Research, 1966.

- Cain GD, Reiner EB, Patterson M. Arch Intern Med, 1968; 122: 311.

- Campbell AGM, Rasenberg LE, Snodgrass PJ, Nuzum CT. N Eng J Med, 1973; 288: 1.

- Chang CA, McKenna RD, Beck IT. Gut, 1968; $9: 420$.

- Charbon GA, Mark van der P. In: Granger DN, Bulkley GB, eds. Measurement of blood flow, Williams and Wilkins, Baltimore 1981: 125.

- Cheng SH, Whitte A. N Engl J Med, 1962; 267: 1296.

- Christison GI, Curtin TM. Lab Anim Care, 1969; 19: 259,

- Cloete C. II Liq Chromat, 1984; 7: 1979.

- Combe E, Pion R. Ann Biol Anim Biochem Biophys, 1966; 262:685.

- Conn HO. Gastroentenology, 1978; 74: 624.

- Conn HO, Kuljian AA. J Lab Clin Med, 1964; 63: 1033.

- Conn HO, Flock MH. Am J Clin Nutr, 1970; 23: 1588.

- Conn HO, Lieberthal MM. Williams and Wilkins, Baltimore, 1979.

- Conner GH, Pries GF. Am J Vet Res, 1960; $21: 1028$.

- Cooper AJL, Ehrlich ME, Plum F. Lancet, 1984; 2: 158.

- Crossley IR, Williams R Gut, 1984; 25: 87.

- DaFonseca Wollheim $\mathbb{F}$. Z Klin Chem Klin Biochem, 1973; 11: 421.

- DaFonseca Wollheim $F_{0}$ Bergmeyer HU, Gutman J. Methoden der enzymatischen Analyse. Verlag, Chemie Weinyheim, 1974.

- Dawson AM, McLaren J, Sherlock S. Lancet, 1957; 2: 1263.

- Dayhof MO (ed). Washington DC: National Biomedical Research Foundation, 1972.

- Delaney JP. Am J Physiol, 1969; 216: 1556.

- Dent CE, Schilling JA. Biochem I, 1949; 44: 318.

- Denton AE, Gershoff SN, Elvehjem CA. J Biol Chem, 1953; 204: 731.

- Deutz NEP. Thesis, University of Amsterdam, Amsterdam, The Netherlands, 1988.

- Deyl Z, Hyanek J. J Chromatogr, 1986; 379; 177.

- Dobbins WO, Herrero BA, Mansbach CM. Am J Med Sci, 1968; 255: 63.

- Douglas WR. Space Life Sciences, 1972; 3: 226.

- Douwes AC, Burg GJ, Bouman AA, Jakobs C, Klei van der - Moorsel van JM, Kneepkens CMP. Lancet, 1987: 688 .

- Editorial. Lancet, 1983: 625.

- Editorial. Lancet, 1987: 81.

- Eggum BO. Br J Nutr, 1970, 24: 983.

- Bijk van HMH, Heijden van der MAH, Berlo van CLH, Soeters PB. Clin Chem, 1988, in press.

- Einarsson S, Josefsson B, Lagerkvist S. J Chromat, 1983; 282: 609.

- Elias E, Gibson GJ, Greenwood LF, Hunt JN, Tripp JHJ Physiol, 1968; 194: 317.

- Elkington SG, Ploch MH, Conn HO. New Engl J Med, 1969; 281: 408.

- Elwyn D. In: Mammalian protein metabolism. Munro NH, ed, 1970; 4.

- Elwyn DH. Fed Proc, 1966; 25: 854.

- Elwyn DH, Launder WJ, Parikh HC, Wise EM. Am J Phys, 1972; 222; 1333. 
- Blwyn DH, Parikh HC, Shoemalker WC Am J Physiol, 1968" 215: 1260.

- Pahey JL, Nathans D, Rairigh D. Am I Med, 1957; 23; 860.

- Pahey JL, Perry RS, McCoy PP. Am J Physiol, 1957; 192: 311.

- Fabey JL. J Clin Invest, 1957; 36: 1647.

- Faloon WW, Fischer CJ. Arch Intern Med, 1959; 103: 43.

- Paloon WW, Fisher CJ. Ann NY Acad Sci, 1958; 76: 196.

- Paloon WW, Ewans GL. NY State J Med, 1970; 2891.

- Paloon WW. Am J Cin Nutr, 1970; 23: 645.

- Pazekers JP, Ticktin HE, Shea JG. Am J Med Sci, 1957; 234: 145.

- Pelig. P. Ann Rev Biachem, 1975; 44: 933.

- Fenton JCB, Kright EJ, Humpherson PL. Lancet, 1966; 1: 164.

- Fersel JM, Conn HO. Gastroenterology, 1972; 62: 191.

- Fischer CJ, Faicoon WW. N Engl J Med, 1957; 256: 1030.

- Mannery DB, Hsia YE, Wolf B. Hepatollogy, 1982; $2 ; 495$.

- Feury MO, Ashley DV. Anal Biochem, 1983; 133: 330.

- Ford JJ, Maurer RR Lab Anim Sci, 1973; 36: 245.

- Funovics JM, Cummings MG, Shuman L, Surgery, 1975; 77: 661.

- Gabuzda Jr GJ, Philips GB, Davidson CS. N Engl J Med ${ }_{*}$ 1952; 246: 124.

- Gardner MG. Biol Rev, 1984; 59: 289.

- Gaustad V. Acta Med Scand, 1949; 135: 354.

- Gay W1. Lab Animal, 1983; 12: 37.

- Gebhardt R, Mecke D. EMBO J, 1983; 2: 567.

- Gips CH, Wibbens Alberts M. Clin Chim Acta, 1968; 22: 1983.

- Godel H, Graser T, Poldi P, Pfaeder P, Fürst P. J Chromatogr, 1984; 297 : 49.

- Golden MH, Jahoor P, Jackson AA. Clin Sci, 1982; 62: 299.

- Graser TA, Godel HG, Albers S, Foldi P, Fürst P. Anal Biochem, 1985; 151: 142.

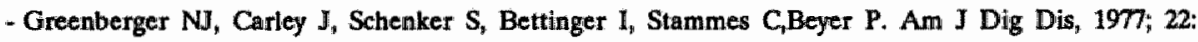
845.

- Greenstein JP, Winitz M, Gullino P, Birnbaum SM, Otey MC. Arch Biochem Biophys, 1956; 64: 342.

- Grenvik A. Scandinaw J Clin Lab Invest, 1966; 18: 486.

- Guidotti GG, Borghetti AF, Gazzola GC. Blochem Biophys Acta, 1978; 515: 329.

- Gullino P, Winitz M, Birnbaum SM, Cornfield J, Otey MC, Gireenstein JP. Arch Blochem Bioplyys, 1956; 64: 319.

- Gutman J, Bergmeyer HU. In methods of enzymatic analysis New York, Academic Press, 1974; 4: 1794.

- Hallett CJ, Cook JGH. Clin Chim Acta, 1971; 35: 33.

- Hamilton RW. J Appl Physiol, 1965; 20; 555.

- Hanson PJ, Parson DS. Biochem J, 1977; 166: 509.

- Hawkins RA, Miller AL, Nielsen RC, Veech RL. Biochem J, 1973: 134: 1001.

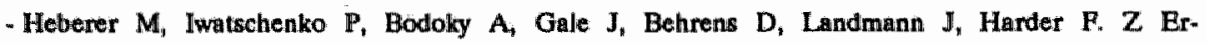
nahrungswiss, 1985; $24: 197$.

- Heinrikson RL, Meredith SC. Anal Biochem, 1984; 136: 65.

- Hellier MD, Holldsworth CD, Perrett D. Gastroenterology, 1973; 65: 613.

- Hill D, Buinmoth L., Skea W, Pfeifer R J Liq Chromat, 1982; 5: 2369.

- Hill DW, Walters FH, Wilson TD, Stuart JD. Anal Chem, 1979; 51: 1338.

- Hilty MD, Romshe CA. J Pediatr, 1974; 84: 362. 
- Hirschfield JS, Kern F. J Clin Invest, 1969; 48: 1224.

- Hirschtield JS, Kern F. Clin Res, 1968; 14: 298.

- Hoffman $\mathbb{K}$, Mossel DA, Horns W, Kamer JH. Klin Wischr, 1964; 42: 126.

- Hop WCJ, Hermans J. T Soc Geneesk, 1981; 59: 279.

- Hör HP. Dissertation, Hannover, $\mathbb{F}_{4}$ R. 1973.

- Hoyumpa AM, Desmond $\mathbf{P}_{*}$ Avant $\mathbf{G}$, Roberts RK, Scheaker S. Gastroenterology 1979; 76: 184.

- Huizenga JR, Gips CH. Ann Clin Biochem, 1983; 20: 187.

- Hunt JN. J Physiol, 1960; 154: 170.

- Hunt IN, McDonald. J Physiol, 1954; 126: 459.

- Hunt JN, Rnox MT. J Physioll, 1968; 194: 327.

- Hutchinson JH, Labby DH. J Lab Clin Med, 1962; 60: 170.

- Hvidt S, Kjeldsen K. Acta Med Scand, 1963; 173: 655.

- Iber F. In: Modern nutrition in health and disease. Goodhart RS, Shils MB eds 1980.

- Imler M, Peter P, Schlienger JL, Lavillaureux J, Stahl J. Med Chir Dig, 1975; 4: 15.

- Iversen LL Lancet, 1982; 2: 914.

- Jackson I, Cook DB, Gill G. Lab Anim Sci, 1972; 22: 552.

- Jacobs RR, Schmitz U, Heyden WC, Roding B, Schenk WG. J Thor Card Surg, 1969; 58: 601.

- Jacobson ED, Prior JT, Faloon WW. J Lab Clin Med, 1960; 56: 245.

- Jacobson ED, Hibbs S, Faloon WW. Am J Clin Nutr, 1962; 10: 325.

- James JH, Jeppsson B, Ziparo V, Fischer JE. Lancet, 1979; 2: 772.

- Janssen MA, Bijk HMH, Heijden van der MAH, Berlo van CLH, Soeters $\mathbb{P B}$. J Hepatol, 1987; 4 suppl: S25.

- Janssen MA, Berlo van CLH, Leeurwen van PAM, Soeters PB. In: Soeters PB, Wilson JHP, Mejjer AJ, Holm E, eds. Advances in Ammonia Metabolism and Hepatic Encephalopathy, 1988: 587.

- Jeppsson B, Kjallman A, Aslund U, Alwmark A, Gullstrand P, Joelsson B. Plenum Press, New York, 1984.

- Jones BN, Paabo S, Stein S. J Liq Chromat, 1981; 4: 565.

- Jones EA. Postgrad Med J, 1983; 59 suppl 4: 42.

- Jones EA, Schafer DF, Ferenci P, Pappas SC. Yale J Biol Med, 1984; 57: 301.

- Jonung T, Jeppsson B, Aslund U, Nair BM. Clin Nutr, 1987; 6: 169.

- Jungblut PW, Lohmann B, Schober R, Turba F. Experientia, 1958; 11: 241.

- Kahn D, Hoorn van - Hickman R, Teublanche J. J Surg Res, 1984; 37: 290.

- Kapadia CR, Mulblbacher F, Smith RJ. Surg Forum, 1982; 33: 19.

- Kardel T, Gips GH. Neth J Med, 1974; $17: 37$.

- Katz ML, Bergman EN. Am J Vet Res, 1969; 30: 655.

- Katz ML, Bergman EN. Am J Physiol, 1969; 216: 946.

- Keshavarzian A, Meck J, Sutton C. Am J Gastroenterol, 1984; 79: 245.

- Ressler II, Sehgal AK, Tumeotte R. Can J Physiol Pharmacol, 1978; 56; 420.

- Kingsley GR, Tager HS. Clin Chem, 1970; 6: 115.

- Kovacevic Z, McGivan JD. Physiol Rev, 1983; 63: 547.

- Kowralsiki HJ, Abelmann WH, McNeeby WF, Frank NR, Ellis LB. Am JM Sc, 1954; 228: 622.

- Lacey RW. J Clin Pathol, 1968; $21: 564$.

- Laplace JP. Xeme Congr Int Zootech, Versailles, 1971.

- Laplace JP. Recl med Vet, 1972; 148: 37.

- Laplace JP. Ann Zootech, 1974; 23: 89.

- Laplace JP, Tomassone R. Ann Zootech, 1970; 19: 303. 
- Leeuren van PAM. Thesis, University of Limburg, Maastricht, The Netherlands, 1985.

- Leewwen van PAM, Janssen MA, Boer de JEG, Goossens HM, Soeterz PB. Advances in Hepatic Encephalopathy and Ure: Cycle Diseases, Basel, 1924: 163.

- Leeuwen van PAM, Berlo van CLH, Soeters PB. Lancet, 1988; 1: 55.

- Leewwen wan PAM, Bogaand van den AEJM, Haaren MJ, Janssen MA, Socters PB. FEMS Micr Lett, 1988; 49: 59.

- Leeuwen van PAM, Bogaand van den AEJM, Janssen MA, Boer de JEG, Eijk van HMH, Soeters PB. Basel, Karger, 1984: 154.

- Levenion SM, Rosen H, Lipjohn HL. Proc Soe Exp Biol Med, 1959; 101: 178.

- Levine RA. Gastroenteroloby "1967; 32: 685"

- Leweling H, Tschepe A, Holm E Leber Magen Darm, 1983; 13: 160.

- Lindroth P, Mopper K Anal Chem, 1979; 51: 1667.

- Loew FM. Lab Animal, 1982; 11: 23.

- Loew FM. In: Granger DN, Bulkley GB, eds, Measurement of blood flow, 1981; Williams and Wilkins, Baltimore: 47.

- Longenecker GB, Hause NL. Nature, 1958; $182: 1739$.

- Lowe WC. Clin Chem, 1968; 14: 1074.

- Lydtin H, Pieper M, Kusus T, Schnelle K, Zollner N. Z Ges Bxp Med, 1969; 149. 279.

- Manolas KJ, Parmer HM, Cussen M, Welboum RB. Cornell Vet, 1983; 73: 333.

- Matsutaka $H_{4}$ Aitwa $\mathbb{P}_{t}$ Yamamoto H, Ischikawa E. J Biochem, 1973; 74: 1019.

- McDermott WV. Bull NY Acad Med, 1958; 34: 352.

- McDermott WV $J_{1}$, Adams RD. J Clin Invest, 1954; 33: 1 .

- Mehnert $\mathrm{H}_{0}$ Fonster H. Diabetologia, 1968; 4; 26.

- Miller ED, Kistner JR, Epstein RM. Anesthesiology, 1980; 52: 296.

- Mills LJ, Simmons DH. J Appl Physiol, 1965; 23: 285.

- Mondzac A, Ehrlich GE, Seegmiller JE. J Lab Clin Med, 1965; 66: 526.

- Morgan MY. Acta Chir Scand, 1981; 507: 98.

- Morgan MY. In: Liver failure, Williams R, ed. 1986, Churchill Livingstone, New York.

- Mount LE, Ingram DL. Academic Press, London and New York, 1971.

- Muhlbacher F, Kapadia CR, Colpoyss MF. Am J Physiol, 1984; 247: E75.

- Munro HN. Mammalian protein metabolism, 1970; IV: 300.

- Munro HN, MeLean EJT, Hird HJ. J Nutr, 1964; 83: 186.

- Murawaki Y, Tanimoto K, Hirayama C, lkuta Y, Watabe N. Clin Chim Acta, 1984; 144: 195.

- Mutchnick MG, Lerner $\mathrm{E}_{\mathrm{y}}$ Conn HO. Gastroenterology, 1974; 66: 1005.

- Müting D, Reilkowskil J. Portsehr Med, 1983; 101: 1610.

- Nance PC, Batson RC, Kline DG. Gastroenterology, 1974; 66: 108.

- Nance FC, Batson RC, KJine DG. Surgery, 1971; 70: 169.

- Newell J. Nurse Practitioner, 1984: 26.

- Noll P. In: Methods of enzymatic analysis, Veriag Chemie Weinheim, 1974; 4: 1475.

- Oberholizer VG, Sehwarz KB, Smith CH, Dietzler DN, Hanna TL Clin Chem, 1976; 22: 1976.

- Ohnhaus EE Br J Clin Pharmacol, 1979; 7: 223.

- Paes IC, Searl P, Rubert MW, Faloon WW. Gastroenterology, 1967; 53: 49.

- Peronneau $P_{n}$ Hinglais J. La Presse Medicale, Paris, 1971; 79: 1225.

- Pfeifer R, Karol $\mathbb{R}$, Korpi J, Burgoyne R, McCourt D. Am Lab, 1983; $15: 78$.

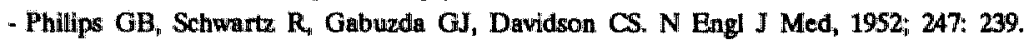

- Phromphetcharat V, Jackson A, Dass PD. Kidney Int, 1981: 20: 598.

- Pion R, Fauconneau G, Rerat A. Ann Biol Anim Biochem Biophys, 1964; 4: 383. 
- Pirk F, Skala I. Digestion, 1970; 3: 73.

- Pitt $\mathrm{P}_{\mathrm{n}}$ Bruijn de KM, Beeching MP, Goldberg $\mathrm{E}$, Blendis LM. Gut, 1980; 21: 951.

- Pond WG, Houpt KA. Ithaca: Comstock Publishing Associates, 1978.

- Powell RC, Nunes WT, Handing RS, Vacea JB. Am J Cin Nutr, 1962; 11: 156.

- Prellwitz W, Kapp S, Dennebaum R. Med Welt, 1976; 27: 1277.

- Purser DB, Klopienstein TJ, Cline JH. J Nutr, 1966; 89: 226.

- Raabe W, Lin S. Brain Res, 1984; 303: 67.

- Raabe W, Lin S. Exp Neurol, 1985; 87: 519.

- Rapoport MI, Feigin RD, Bruton J, Beisel WR Science, 1966; 153: 1642.

- Ratnaike RN, Buttery JE, Malden LT, Chamberlain BR, O'Halloran M. Scand J Gastroenterol, 1982; 18: 103.

- Ratnaike RN, Buttery JB, Hoffman S. J Clin Chem Cin Biochem, 1984; 22: 105.

- Reddy BS, Pleasants JR, Wostmann BS. J Nutr, 1969; 97: 327.

- Rerat A. Med et Nut, $1979 ;$ XV: 31.

- Rerat A. Bull Acad Nat Med, 1981; 165: 1131.

- Rerat A, Vaugelade P, Villiers PA. In: Low AG, Partridge IG: Current concepts of digestion and absorption, 1980; 3: 177 .

- Rerat AA, Corring T, Laplace JP. In: Cole PJA, Boorman KN, Buttery PJ, eds. Protein metabolism and nutrition, 1976: 97.

- Rerat AA. Archives of Animal Nutrition, 1985; 35: 461.

- Rerat AA. Proc Nutr Soc, 1980; 39; 177.

- Rerat AA. Ann Biol Anim Biochem Biophys, 1971; 11: 175.

- Rerat AA, Vaugelade P. Sci Tech Animal Lab, 1983; 8: 239.

- Reynell PC, Spray GH. J Physiol Lond, 1956; 131: 452.

- Rose WC, Wixon RL, Lockhart HB, Lambert GP. J Biol Chem, 1955; 216 : 987.

- Ruderman N. Ann Rev Med, 1975; 26: 245.

- Rudman D, Smith RB, Salam AA, Warren WD, Galambos JT, Wenger J. Am J Clin Nutr, 1973; 26: 487.

- Rudman D, Gatambos JT, Smith RB, Salam AA, Warren WD. Am J Clin Nutr, 1973; 26: 916.

- Sack WO. Ithaca : Veterinary Textbooks, 1982.

- Salter DN. Proc Nutr Soc, 1973; 32: 65.

- Santiesteban R, Hutson D, Dombro RS. Lab Anim Sci, 1983; 33: 373.

- Schambyre P. Nord Vet Med, 1955; 7: 1001.

- Schwartz R, Philips GB, Gabuzda Jr GJ, Davidson GS. J Lab Clin Med, 1953; 42: 499.

- Scriver CR, Davies E Pediatrics, 1965; 36: 592.

- Seigffers MJ, Seggal HL, Miller LL. Am J Physiol, 1963; 205: 1106.

- Seligson D Hirahara K. J Lab Clin Med, 1957; 49: 962.

- Sherlock S, Summerskill WH, White LP, Phear EA. Lancet, 1954; $2: 452$.

- Shimada AM, Zimmerman DR. J Anim Sci, 1973; 36: 245.

- Silen W, Harper HA, Mawdsley DL, Weinrich WL. Proc Soc Bxp Biol, 1955; 88: 138.

- Slyke van DD, Meyer GM. J Biol Chem, 1913; 16: 231.

- Smith RB, Vorhees AB, Davidson EA, Barker HG. Surg Forum, 1964;15:98.

- Smith RJ, Panico KA. J Liq Chromat, 1985; 8: 1783.

- Soeters PB, Wilson JHP, Meijer AJ, Holm E, eds. Advanees in Ammonia Metabolism and Hepatic Encephalopathy, 1988.

- Souba WW, Smith RJ, Wilmore DW. Metabolism, 1985;34:450.

- Souba WW, Wilmore DW. Surgery, 1983; 94: 342. 
- Souba WW. Thesis, Harvard School of Public Health, Boston, U.S.A., 1984.

- Souba WW, Smith RI, Wilmore DW. JPEN, 1985; 9:608.

- Squilbib RL. I Nutr, 1966; 90: 71.

- Stall J, Roger S, Witz J. Cell R Soc Biol, 1952; 146: 1787.

- Stormont JM, Machic JE, Davidson CS. N Engl J Med, 1958; 259: 1145.

- Sugarbaker SP, Rewhaug A, Wilmore DW. Ann Surg, 1987; 206: 5 .

- Summertkill WHJ. Br Med J, 1953; 29: 1322.

- Summerskill WHJ, Davidson EA, Sherlock S, Steiner RE. O J Med, 1956; $25: 245$.

- Summerskill WHU, Wolfe SJ, Davidson CS. Am J Med, 1957; 23: 59.

- Swindle MM, Bobbic DL. Basic surgical exercises using swine, Praeger, New York, 1983.

- Tada K, Okuda K, Watanabe K, Limura X, Yamada S. Eur J Pediatr, 1979; 130: 105.

- Takahashi H. Lab Anim Sci, 1986; 20: 206.

- Twnaka P. Bull Kobe Med Coll, 1962; 212: 328.

- Taylor WH. In: Handbook of Physiol; 6. Alimentary Canal, 1968: 5.

- Tranquilli WJ, Thurmon JC, Benson GJ. Am J Vet Res, 1982; 44: 1578.

- Twombley J, Meyer JH. J Nutr, 1961; 74: 453.

- Udall JA. JAMA, 1965; 194: 127.

- Uribe M, Dibildox M, Malpica S. Gastroenterology, 1985; 88: 901.

- Uribe M, Marquez MA, Garcia Ramos G. Dig Dis Sci, 1982; 27: 1109.

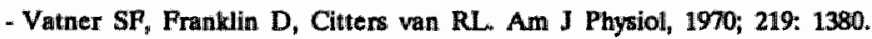

- Vente JP, Meyenfeldt won MP, Rouflart M, Berlo van CLH, Eijk van HMH, Soeters PB. Clin Nutr, 1986; 5: 60.

- Vesalinus. Fabrica, 1543.

- Vince A, Killingley M, Wrong OM. Gastroenterology, 1978; 74: 544.

- Vince A, Zeegen R, Drinkwater JE, O'Grady F, Dawson Am J Med Microbiol, 1974; 7: 163.

- Vince A, Burridge SM. J Med Microbiol, 1980; 13: 177.

- Wahdati von A, Sommer H. Ber' Munch Tiertiratl Wschr, 1979; 92: 142.

- Walser Mr Bodeniloos LJ. J Clin Invest, 1959; 38: 1617.

- Walter AM, Hellmeyer L. Georg Thieme Verlag, Stuttgart, 1976.

- Weber FL, Veach GL. Gastroenterology, 1979; 77: 235.

- Weber FL. Gastroenterology, 1979; 77: 518.

- Weber FL, Fresard KM. Gastroenterology, 1981; 80: 994.

- Weirich WE, Will JA, Crumpton CW. I Appi Physiol, 1970; 28: 117.

- Welch CS, Kiley JE, Reeve TS, Goodrich EO, Welch HF. N Engl J Med, 1956; 254: 493.

- White L.P, Phear EA, Summerskill WHJ, Sherlock S. J Clin Invest, 1955; 34: 158.

- Windmueller HG. In: Meister A: Advances in Enzymology, 1982, Wiley and Sons, New York, 202.

- Windmueller HO, Spacth AB. J Biol Chem, 1978; 253: 69.

- Windmueller HG, Spaeth AR Arch Biochem Biophys, 1975; 171: 662

- Windmueller HG, Spaeth AE. J Biol Chem, 1980, 255: 107.

- Windmueller HG, Spaeth AB. J Biol Chem, 1974; 249: 5070.

- Wingfield WE, Tumbleson ME, Hicklin KW, Mather EC. Lab Anim Sci, 1974; 24: 359.

- Winter CO, Christensen HN. J Biol Chem, 1964; 239: 872.

- Witzel DA, Littledice ET, Cook HM. Comell Vet, 1973; 63: 432.

- Wolf JE, Bergman BM, Williams HH. Am J Physiol, 1972; 223: 438.

- Woiff JE, Bergman EN, Williams HH. Am I Physiol, 1974; 226: 1428.

- Wolpert E, Phillps SF, Summerskill WHJ. New Bngl J Med, 1970; 283: 159.

- Wunner WH, Bell J, Munro HN. J Biochem, 1966; 101: 417. 
- Wurtman RJ, Rose CM, Chou C, Larin FF. New Engi J Med, 1968; 279: 171.

- Wyatt DG. Med Biol Eng Comp, 1984: 193.

- Young PC, Burnside CR, Knowles HC, Schiff L. J Lab Clin Med, 1957; 50: 11.

- Zeneroli ML, Iuliamo $\mathbb{E}_{n}$ Racagni G, Baraldi M. J Neurochen, 1982; $38: 1219$.

- Zeneroli ML, Ventura E, Baralli M, Penne A, Messori E, Zieve L. Hepatology, 1982; 2: 532.

- Zieve L. Hepatology, 1981; 1: 360. 


\section{Curriculum vitae}

Carolus Leonardus Hubertus van Berlo was born on the 4th of July 1958 in Maastricht. He attended high school in Maastricht (St. Maartenscollege, Gymnasium B) and went to Medical School at the University of Utrecht (19761983). From 1979-1981 he was a research assistant in histology (Prof Dr M.T. Jansen and Dr C.J.H. van den Broek). In 1981 he was a research assistant in anatomy (Prof Dr W.J. van Doorenmaalen). From 1983-1984 he worked as a resident in surgery at the St. Elisabeth Hospital, Tilburg (Head Dr Th.J.M.V. van Vroonhoven). From 1984-1985 he participated as a member of the Nutritional Support Team (Head. Dr P.B. Soeters) in a clinical study evaluating the effects of branched chain amino acids in critically ill patients. From 1985 until 1988 he was a research fellow in the Biomedical Center, University of Limburg, where the experimental work of this thesis was performed, under the guidance of Prof Dr P.B. Soeters. From april 1988 to june 1988 he attended the laboratory of Prof D.W. Wilmore, Boston. At present he is a resident in surgery at the University Hospital Maastricht. 


\section{Dankwoord}

Het verschijnen van dit proefschrift was alleen mogelijk met de hulp van vele anderen.

Op de eerste plaats wil ik hier mijn ouders bedanken, die mij altijd hebben gesteund en gestimuleerd.

Prof dr J.M. Greep en Prof dr G. Kootstra gaven mij de gelegentheid binnen de Capaciteitsgroep Algemene Heelkunde gedurende drie jaar full-time onderzoek te verrichten.

Prof dr P.B. Soeters, beste Peter, jouw visie op de research binnen de Heelkunde in Nederland vormde de basis voor dit proefschrift. Jouw aanpak van mij en het onderwerp verhelderde zonodig beide. Al wilde ik zelf vaak sneller, in alle rust wist je mijn enthousiasme in goede banen te leiden. Hiervoor ben ik niet alleen jou, maar ook je gezin veel dank verschuldigd.

Dr M.F. von Meyenfeldt, beste Maarten, tijdens de BCAA-studie leerde jij me niêt alleen de weg naar het B.M.C. te vinden.

Margriet Rouflart, de typische wijze waarop jij de link tussen B.M.C. en kliniek duidelijk maakte, zal ik niet licht vergeten.

Dr J.G. Maessen, beste Jos, de combinatie van koffiegeur en pijptabak zijn voor mij onlosmakelijk met jou verbonden. Je visie op computers, in de vorm van Sinclair's QL, konden we helaas niet tot het einde trouw blijven. Je Maastrichtse discussieertrant blijf ik waarderen.

De leden van de beoordelingscommissie, Prof dr F. ten Hoor, Prof dr M.A. Allessie, dr R.A.F.M. Chamuleau, Prof dr J.A. Flendrig en Prof dr J.H.P. Wilson dank ik voor de kritische wijze waarop zij het manuscript beoordeelden.

Mevrouw en mijnheer Limpens stonden dag en nacht voor het onderzoek klaar. Frans Slangen en Peter Franssen verzorgden de proefdieren. May Bost regelde "alles" peri-operatief. Ton van den Bogaard liet binnen het C.P.V. alles vlot verlopen.

Prof dr G.A. Charbon introduceerde mij in de wereld van electromagnetisch flow meten. Dr. T.H.M. Hasaart, Theo van de Nagel en Ruud Kruger waren behulpzaam bij de chronische flowmetingen.

Hans van Eijk, Marion van der Heijden, Mieke Janssen en Peter van de Klundert, blekem op grote proefdagen gezamenlijk telkens weer in staat monsterafname, metingen en analyses te verzorgen en de uiteindelijk verkregen resultaten klaar te maken voor computerverwerking. 
Prof D.W. Wilmore ben ik erkentelijk voor de gesprekken die wij naar aanleiding van het manuscript van dit proefschrift konden voeren. Ken Mealy deed zijin best het 'engels' te corrigeren.

Marcia van Puyenbroek en Johan van Dongen, jullie ben ik dankbaar voor vele gesprekken en geregel.

Dr P.A.M. van Leeuwen, beste Paul, jouw proeven baanden de weg voor het grote model. Je niet altijd makkelijke, relativerende, opmerkingen stelde ik op prijs.

Bewust van het feit dat ik niet iedereen persoonlijk kan noemen wil ik een ieder die op welke wijze dan ook heeft bijgedragen aan het tot stand komen van dit proefschrift danken.

Marijke, jou beloof ik, in ruil voor getrotseerde verwaarlozing een maand computeronthouding. 